\title{
Caracterização da estrutura \\ de dependência do genoma humano \\ usando campos Markovianos - \\ Estudo de populações mundiais e dados de SNPs
}

Francisco José de Almeida Fernandes

\author{
DisSERTAÇÃo APRESENTADA \\ $\mathrm{AO}$ \\ Instituto de MatemáticA e Estatística \\ DA \\ Universidade DE SÃo PAUlo \\ PARA \\ OBTENÇÃO DO TÍTULO \\ DE \\ Mestre em CiênCias \\ Programa: Estatística \\ Orientador: Profa. Dra. Júlia Maria Pavan Soler
}

São Paulo, fevereiro de 2016 
Caracterização da estrutura de dependência do genoma humano usando campos Markovianos - Estudo de populações mundiais e dados de SNPs

\begin{abstract}
Esta versão da dissertação contém as correções e alterações sugeridas pela Comissão Julgadora durante a defesa da versão original do trabalho, realizada em 01/02/2016. Uma cópia da versão original está disponível no Instituto de Matemática e Estatística da Universidade de São Paulo.
\end{abstract}

Comissão Julgadora:

- Prof ${ }^{\mathrm{a}}$. Dr ${ }^{\mathrm{a}}$. Júlia Maria Pavan Soler - IME-USP

- Prof ${ }^{\mathrm{a}}$. Dr ${ }^{\mathrm{a}}$. Lúcia Pereira Barroso - IME-USP

- Prof ${ }^{\mathrm{a}}$. Dr ${ }^{\mathrm{a}}$. Suely Ruiz Giolo - UFPR 
Muitas pessoas deveriam ser citadas neste agradecimento, muitos colegas, professores e amigos que de uma forma ou de outra, seja ajudando a eliminar uma dúvida, seja nas palavras de conforto e incentivo, me ajudaram a enfrentar todos os desafios e atingir este objetivo. Não gostaria de citálos nominalmente para não correr o risco de, por alguma falha de minha parte, esquecer algum deles.

Muito deste trabalho é continuação da iniciação científica de Andressa Cerqueira e da monografia de André Bianchi, aos quais faço aqui um especial destaque. À doutora Suely Giolo agradeço pelo fornecimento do arquivo de dados, matéria prima deste trabalho.

Agradeço ao meu pai por ter provado que apenas no dicionário, sucesso pode vir antes de trabalho; à minha mãe por ter colocado em mim o fascínio por essa máquina chamada "corpo humano"; à minha esposa pelo seu otimismo sem medidas; aos meus filhos pela importância que deram a este trabalho; à profa. dra. Florencia Leonardi por ter sido a primeira a acreditar que eu poderia chegar até aqui; à profa. dra. Júlia M P Soler, porque mais do que uma orientadora, foi cúmplice desta dissertação e, acima de tudo, agradeço a Deus, por ter permitido todas essas pessoas tão próximas a mim.

"A grandeza não consiste apenas em receber honras, mas em merecê-las"(Aristóteles) 


\section{Resumo}

FERNANDES, F. J. A. Caracterização da estrutura de dependência do genoma humano usando campos Markovianos - estudo de populações mundiais e dados de SNPs. 2016. 79 f. Dissertação (Mestrado) - Instituto de Matemática e Estatística, Universidade de São Paulo, São Paulo, 2016.

A identificação de regiões cromossômicas, ou blocos de dependência dentro do genoma humano, que são transmitidas em conjunto para seus descendentes (haplótipos) tem sido um desafio e alvo de várias iniciativas de pesquisa, muitas delas utilizando dados de plataformas de marcadores moleculares do tipo SNP (Single Nucleotide Polymorphisms - SNPs), com alta densidade dentro do DNA humano. Este trabalho faz uso de uma modelagem estocástica de campos Markovianos de alcance variável, em uma amostra estratificada de diferentes populações, para encontrar blocos de SNPs, independentes entre si, estruturando assim o genoma em regiões ilhadas de dependência. Foram utilizados dados públicos de SNPs de diferentes populações mundiais (projeto HapMap), além de uma amostra da população brasileira. As regiões de dependência configuram janelas de influência as quais foram usadas para caracterizar as diferentes populações de acordo com sua ancestralidade e os resultados obtidos mostraram que as janelas da população brasileira têm, em média, tamanho maior, evidenciando a sua história recente de miscigenação. É também proposta uma otimização da função de verossimilhança do problema para obter as janelas de consenso maximais de todas as populações. Dada uma determinada janela de consenso, uma medida de distância apropriada para variáveis categóricas, é adotada para medir sua homogeneidade/heterogeneidade. Janelas homogêneas foram identificadas na região HLA (Human Leukocyte Antigen) do genoma, a qual está associada à resposta imunológica. O tamanho médio dessas janelas foi maior do que a média encontrada no restante do cromossomo, confirmando a alta dependência existente nesta região, considerada como bastante conservada na evolução humana. Finalmente, considerando a distribuição dos SNPs entre as populações nas janelas mais heterogêneas, a Análise de Correspondência foi aplicada na construção de um classificador capaz de determinar o percentual relativo de ancestralidade de um indivíduo, o qual, submetido à validação, obteve uma eficiência de $90 \%$ de acerto da população originária.

Palavras-chave: campos Markovianos de alcance variável, HapMap, blocos de SNPs, ancestralidade, miscigenação 


\section{Abstract}

FERNANDES, F. J. A. Characterization of the human genome dependence structure using Markov random fields - populations worldwide study and SNP data. 2016. 79 f. Dissertation (master's degree) - Mathematics and Statistical Institute, University at São Paulo, São Paulo, 2016.

The identification of chromosome regions, or dependency blocks in the human genome, that are transmitted together to offspring (haploids) has been a challenge and object of several research initiatives, many of them using platforms of molecular markers such as SNP (Single Nucleotide Polymorphisms), with high density inside the human DNA. This work makes use of a stochastic modeling of Markov random fields, in a stratified sample of different populations, to find SNPs blocks, independent of each other, thus structuring the genome in stranded regions of dependency. Public data from different worldwide populations were used (HapMap project), beyond a Brazilian population. The dependence regions constitute windows of influence which were used to characterize the different populations according of their ancestry and the results showed that the Brazilian population's windows have, on average, a bigger size, showing their recent history of admixture. It is also proposed an optimization of likelihood function of the problem for the maximal windows of consensus from all populations. Given a particular window of consensus, a distance measure appropriated to categorical variables, it is adopted to evaluate its homogeneity/heterogeneity. Homogeneous windows were identified within region of genome called HLA (Human Leukocyte Antigen), which is associated with the immune response. The average size of these windows was bigger than the average found in the rest of the chromosome, confirming the high dependence verified in this region, considered highly conserved in the human evolution. Finally, considering the distribution of the SNPs among the populations in the most heterogeneous windows, the Correspondence Analysis was applied to build a classifier able to determine, for a given individual, the ancestry proportion from each population considered, which, submitted to a validation, obtained a $90 \%$ accuracy of the original population.

Keywords: variable range Markov random fields, HapMap, SNP blocks, ancestry, admixture 


\section{Sumário}

$\begin{array}{lc}\text { Lista de Abreviaturas } & \text { ix }\end{array}$

Lista de Figuras $\quad$ xi

Lista de Tabelas $\quad$ xiii

1 Introdução $\quad 1$

1.1 Genoma Humano, SNPs e o Projeto HapMap . . . . . . . . . . . . . . . . . . 1

1.2 Estudos de Regiões de Dependência no Genoma . . . . . . . . . . . . . . . . . . . 2

1.3 Ancestralidade . . . . . . . . . . . . . . . . . . . . 4



1.5 Organização do Trabalho . . . . . . . . . . . . . . . . . . . 7

2 Modelagem da Estrutura de Dependência do Genoma $\quad 9$

2.1 Notação . . . . . . . . . . . . . . . . . . . . . . . . . . . . . . 9

2.1.1 Modelagem por Campos Markovianos . . . . . . . . . . . . . . . . 11

2.1 .2 Vizinhança . . . . . . . . . . . . . . . . . . . . . . . . . . 12

2.2 Função de Verossimilhança . . . . . . . . . . . . . . . . . . . . . . . . . . 12

2.2 .1 Algoritmo . . . . . . . . . . . . . . . . . . . . . . . . . . . . . 14

$2.2 .2 \quad$ Janelas de Influência . . . . . . . . . . . . . . . . . . . . . . 15

2.3 Estratificação Populacional . . . . . . . . . . . . . . . . . . . . . . . 15

2.4 Janelas de Consenso . . . . . . . . . . . . . . . . . . . . . . . . 16

3 Caracterização das Janelas de Consenso e Classificação das Observações 19

3.1 Índice de Heterogeneidade $(\mathrm{IH}) \ldots \ldots \ldots \ldots \ldots$

3.2 Classificador . . . . . . . . . . . . . . . . . . . . . . . 22

3.2.1 Análise de Correspondência - Representação Gráfica . . . . . . . . . . . . . 23

3.2 .2 Mapa Biplot . . . . . . . . . . . . . . . . . . . . . 25

4 Aplicação - Análise das Janelas de Influência na História Ancestral das Populações $\quad 27$

4.1 Preparação e Descrição dos Dados Utilizados no Estudo . . . . . . . . . . . . . . . 27

4.2 Parte I - Estimação e Estudo das Janelas de Influência . . . . . . . . . . . . . . . . 30

4.2.1 Tamanhos das Janelas de Cada População . . . . . . . . . . . . . . . . . . 30

4.2 .2 Distribuição das Janelas por População . . . . . . . . . . . . . . . . . . . . 31

4.2.3 Comparação de Resultados Extremos . . . . . . . . . . . . . . . . . . . . . . 32 
4.3 Parte II - Estimação e Estudo das Janelas de Consenso . . . . . . . . . . . . . . . . . 33

4.3.1 Caracterização das Janelas de Consenso Maximal . . . . . . . . . . . . . . . . 36

4.3.2 Região HLA do Genoma - Janelas Homogêneas . . . . . . . . . . . . . . . . . 37

4.3.3 Classificador - Janelas Heterogêneas ． . . . . . . . . . . . . . . . . . . . . 41

5 Considerações Finais $\quad 45$

5.1 Conclusões e Contribuições . . . . . . . . . . . . . . . . . . . . 45

5.2 Estudos Futuros . . . . . . . . . . . . . . . . . . . 47

A Apêndice $\quad 51$

A.1 Códigos Fonte . . . . . . . . . . . . . . . . . . . . . 51

A.1.1 Recodificação dos $\operatorname{SNPs} \ldots \ldots \ldots \ldots \ldots$. . . . . . . . . . . . . 51

A.1.2 Janelas de Consenso . . . . . . . . . . . . . . . . . . . . . . . 53

A.1.3 Classificador . . . . . . . . . . . . . . . . . . . 55

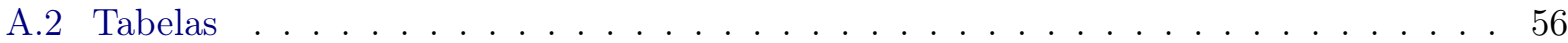



$\begin{array}{ll}\text { Referências Bibliográficas } & 61\end{array}$ 


\section{Lista de Abreviaturas}

DNA molécula formadora do genoma (ácido desoxirribonucleico)

SNP Single Nucleotide Polymorphism - Polimorfismos de nucleotídeo único

LD Linkage Disequilibrium - Desequilíbrio de Ligação

HLA Human Leukocyte Antigen - região específica do DNA

MCMC Markov Chain Monte Carlo - Monte Carlo em Cadeias de Markov

HMC Hiden Markov Chain - Cadeias de Markov escondidas

Jp janelas de influência populacionais, particulares de cada população

Jc janelas de consenso entre as populações

Jt janelas de influência adotando todas as populações como uma única amostra

AC Análise de Correspondência

ACS Análise de Correspondência Simples

IH Indice de Heterogeneidade

IS Índice de Similaridade

PLINK programa de código aberto para análise de dados genéticos 


\section{Lista de Figuras}

1.1 Ilustração da presença de um SNP (alteração de um único par de bases) em uma região do genoma. . . . . . . . . . . . . . . . . . . 2

1.2 História ancestral das populações - uma visão ilustrativa . . . . . . . . . . . . . 5

1.3 Localização geográfica aproximada das populações utilizadas no estudo. . . . . . . . 7

1.4 Fluxograma das etapas do trabalho . . . . . . . . . . . . . . . . . . . 8

2.1 Algoritmo de árvore de contexto: exemplo para uma vizinhança de tamanho $3 . \quad$. . . 15

2.2 Visão esquemática da construção de janelas de influência de SNPs. . . . . . . . . . . 15

2.3 Esquema ilustrando a construção de uma janela de consenso maximal. . . . . . . . . . 17

3.1 Exemplos de janelas de consenso heterogênea e homogênea. . . . . . . . . . . . . . 20

3.2 Exemplo hipotético para ilustrar o procedimento de cálculo dos índices de heterogeneidade (IH) e similaridade (IS) . . . . . . . . . . . . . . . . . 21

3.3 Gráfico mostrando os perfis linha da Tabela 3.1 em coordenadas triangulares . . . . . 24

4.1 Distribuição dos 365.116 SNPs comuns às populações ao longo dos 22 cromossomos

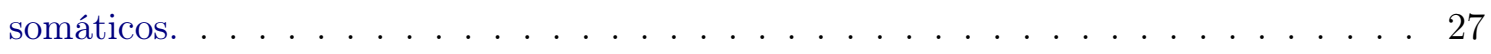

4.2 Número de janelas por população. . . . . . . . . . . . . . . . . . . . 31

4.3 Tamanho médio das janelas por população. . . . . . . . . . . . . . . . . 31

4.4 Distribuição do tamanho médio das janelas por população. . . . . . . . . . . . . . . . 31

4.5 Comparação da distribuição das janelas maiores nas populações ASW e BRZ. . . . . 32

4.6 Distribuição das janelas por cromossomo nas populações ASW e BRZ. . . . . . . . . . 33

4.7 Exemplo das janelas de influência obtidas para cada população nos primeiros SNPs do cromossomo 1. Indicação das respectivas janelas de consenso maximal das populações e as janelas obtidas para toda a amostra sem segmentação por população. . . . . . . 35

4.8 Boxplot dos índices IS e IH por cromossomo. . . . . . . . . . . . . . . . 36

4.9 Dispersão dos índices IS e IH (a linha vermelha representa a mediana do índice

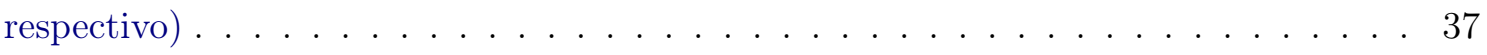

4.10 Cromossomo 6 com a região HLA em destaque. . . . . . . . . . . . . . . 37

4.11 Mapa das regiões HLA no cromossomo $6 \ldots \ldots \ldots \ldots$

4.12 SNPs comuns na região HLA-DOB e as janelas de influência e de consenso do entorno. 39

4.13 Comparação dos tamanhos das janelas de consenso na região HLA e no cromossomo 6. 39

4.14 Exemplo do Biplot bidimensional produzido pela ACS da Tabela 4.7 . . . . . . . . . 42

4.15 Exemplo do Biplot bidimensional produzido para uma janela com mais de três genótipos. . . . . . . . . . . . . . . . . . . . . . . . 42 
4.16 Classificação utilizando mapa Biplot . . . . . . . . . . . . . . . . . . . . . 43

5.1 Comparação entre alguns resultados obtidos por Greenspam e Geiger (Greenspan e Geiger, 2006), com os deste trabalho. . . . . . . . . . . . . . . . . . . . 49

A.1 Distribuição das janelas 'grandes' em cada população do estudo. . . . . . . . . . . . . . 59

A.2 Janelas encontradas nas regiões dos SNPs da região do HLA. . . . . . . . . . . . . . 60 


\section{Lista de Tabelas}

1.1 Populações disponíveis no projeto HapMap. . . . . . . . . . . . . . . . . . . . . . 2

2.1 Exemplos da codificação adotada para cada SNP. . . . . . . . . . . . . . . . . . 10

3.1 Tabela de contingência hipotética representativa de uma janela contendo 3 diferentes genótipos (G1, G2, G3) em 5 populações (P1, P2, P3, P4, P5). Valores entre parênteses são as frequências relativas. . . . . . . . . . . . . . 23

4.1 Populações amostradas e número de indivíduos considerados no estudo . . . . . . . . 28

4.2 Número de SNPs e as Janelas obtidas por população para cada cromossomo . . . . 29

4.3 Agrupamento das populações segundo sua ancestralidade primária . . . . . . . . . . . 30

4.4 Tabela resumo das regiões HLA encontradas . . . . . . . . . . . . . . . . 38

4.5 Janelas de consenso existentes nas regiões HLA encontradas . . . . . . . . . . . . . 40

4.6 Distribuição das janelas heterogêneas com IH $>50 \%$ ao longo dos cromossomos . . . . 41

4.7 Exemplo da tabela de contingência do classificador . . . . . . . . . . . . . . . . . 41

4.8 Tabela de validação do classificador . . . . . . . . . . . . . . . . . . . . . 43

4.9 Tabela resumida mostrando os resultados obtidos para o classificador, em diferentes amostras e utilizando diferentes janelas de consenso. . . . . . . . . . . . . . . . . . 44

A.1 Classificação utilizando mapa Biplot . . . . . . . . . . . . . . . . . . 57 


\section{Capítulo 1}

\section{Introdução}

\subsection{Genoma Humano, SNPs e o Projeto HapMap}

Desde o anúncio e publicação em fevereiro de 2001 dos primeiros rascunhos do genoma humano, feito separadamente pelo Consórcio Internacional para Sequenciamento do Genoma Humano (IHGSC - International Human Genome Sequencing Consortium) e pela empresa Celera Genomics Corporation, pesquisadores do mundo todo têm se debruçado sobre a sequência de mais de 3 bilhões de pares de bases nitrogenadas (nucleotídeos) na busca de compreender como cada pedaço do genoma é responsável por nossa diversidade, onde estão as causas das anomalias, doenças, síndromes, etc.

O genoma humano é formado por moléculas químicas longas (DNA - ácido desoxirribonucleico) contendo duas fitas formadas por moléculas de açúcar (desoxirribose) e fosfato, unidas por pares de bases nitrogenadas de quatro tipos: A (adenina), C (citosina), T (timina) e G (guanina). O DNA está estruturado em organelas celulares denominadas cromossomos, os quais aparecem aos pares, sendo um proveniente da mãe e outro do pai, razão pela qual somos classificados em seres do tipo diplóide (dois cromossomos homólogos). Regiões cromossômicas que são transmitidas diretamente de um dos pais são denominadas haplótipos e muitos trabalhos de pesquisa têm como foco principal a identificação desses blocos, utilizando diferentes abordagens e propondo algoritmos distintos para tal (Geraci, 2010).

Os genes são sequências de nucleotídeos ao longo de uma ou mais regiões do DNA que contêm a codificação química para a elaboração de proteínas (Lesk, 2005), identificados em uma posição determinada de um cromossomo, chamada loco. Alelos são formas alternativas de bases nitrogenadas presentes em cromossomos homólogos, num mesmo loco. Assim, dado um determinado loco, as bases nitrogenadas dos alelos formam o que chamamos genótipo do indivíduo naquele loco. Muito importante é notar, portanto, a diferença entre montagem de haplótipos, que são regiões genômicas num mesmo cromossomo, versus montagem de genótipos, que correspondem à informação genética de um loco nos dois cromossomos homólogos ${ }^{1}$.

Quando existem variações genéticas entre indivíduos para um mesmo loco, este é chamado

\footnotetext{
${ }^{1}$ Particularmente, neste trabalho, utiliza-se a informação genotípica.
} 


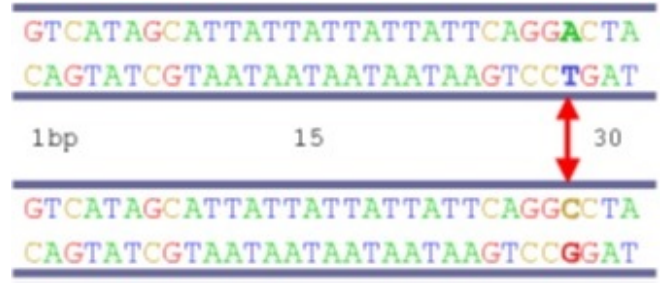

Figura 1.1: Ilustração da presença de um SNP (alteração de um único par de bases) em uma região do genoma.

Tabela 1.1: Populações disponíveis no projeto HapMap.

\begin{tabular}{ll}
\hline Rótulo & Origem da População \\
\hline ASW & população do sudoeste dos EUA com ancestralidade africana \\
CEU & residentes de Utah com ancestralidade do norte e ocidente da Europa \\
CHB & chineses em Beijing, China, com ancestralidade da dinastia Han \\
CHD & chineses residentes na área metropolitana de Denver, Colorado \\
GIH & índios Gujarati em Houston, Texas \\
JPT & japoneses em Tokyo, Japão \\
LWK & residentes em Webuye, Quênia com ancestralidade Luhya \\
MEX & residentes em Los Angeles, Califórnia com ancestralidade mexicana \\
MKK & residentes em Kinyawa, Quênia com ancestralidade Maasai \\
TSI & residentes próximos a Florência, Itália com ancestralidade toscana \\
YRI & residentes em Ibadan, Nigéria com ancestralidade Yoruba \\
BRZ & brasileiros residentes em Baependi, Minas Gerais \\
\hline
\end{tabular}

polimórfico. Entre os diferentes tipos de polimorfismos, destacam-se os SNPs (Single Nucleotide Polymorphisms - SNPs), quando há alteração em apenas um único par de bases (ver Figura 1.1). Os SNPs estão distribuídos ao longo de todo o genoma, são originados de mutações e dada sua alta densidade podem ser utilizados como marcadores moleculares estáveis no mapeamento de genes (Lesk, 2005). Por estas características, têm sido utilizados em vários trabalhos científicos como amostradores do genoma, de fato, os SNPs podem ser utilizados para amostrar o genoma com uma cobertura representativa de sua variabilidade.

O projeto HapMap (Consortium et al., 2005) é um consórcio formado por vários países com o objetivo de identificar e catalogar as diferenças e similaridades entre o genoma de seres humanos através do levantamento do mapa dos SNPs em várias populações humanas (ver Tabela 1.1), distribuídas em regiões geográficas distintas e com diferentes ancestralidades. Com início em 2002, disponibiliza informações genotípicas, bem como haplotípicas, das populações estudadas, as quais podem ser utilizadas para identificar regiões cromossômicas onde variantes genéticas são compartilhadas, além de ajudar no mapeamento de genes, isto é, na identificação de genes associados a doenças ou envolvidos na resposta terapêutica às drogas.

\subsection{Estudos de Regiões de Dependência no Genoma}

A montagem de haplótipos e o mapeamento de genes são apenas dois exemplos da importância de se encontrar regiões genômicas contíguas e com significado biológico, estatisticamente falando, 
regiões que guardam dependência interna na distribuição de seus nucleotídeos. Este trabalho tem por objetivo contribuir na identificação desses blocos de dependência que ocorrem dentro do genoma humano.

Entre as medidas probabilísticas de dependência interna do genoma, destaca-se o desequilíbrio de ligação ou $L D$ do inglês Linkage Disequilibrium, definido como a associação entre alelos (ou genótipos) em diferentes locos, um indicador sensível das forças genéticas que estruturam o genoma (Slatkin, 2008). O desequilíbrio de ligação representa a fuga da independência na distribuição dos alelos (ou genótipos) em diferentes locos e, portanto, quando alelos de dois locos são encontrados juntos mais do que esperado sob independência, há evidência de LD. Quando da formação das células reprodutoras no processo denominado de meiose, há a possibilidade de troca de pedaços de genoma nos cromossomos homólogos, fenômeno conhecido como recombinação gênica. Os eventos de recombinação entre dois locos são avaliados segundo um parâmetro $\lambda$, que varia entre 0 e 0,5 . Quanto mais próximo $\lambda$ estiver de 0 , mais próximos (em distância genética) estão os dois locos e, portanto, menor a probabilidade de haver recombinação gênica nesse intervalo, consequentemente, maior o LD entre estes locos. Apesar de, em um contexto geral, ambas as medidas serem usadas no estudo de associação entre locos genéticos, não há uma função estabelecendo uma relação direta entre LD e recombinação gênica (Lange, 2002).

Uma utilização importante da análise do LD é no mapeamento de doenças, isto é, na identificação de marcadores (por exemplo, SNPs) em LD com mutações causais para doenças. Quando uma mutação desse tipo é introduzida em uma população, ela necessariamente estará situada em um haplótipo, cercada por outros marcadores moleculares que estarão em completo desequilíbrio de ligação com a mutação, ou seja, encontra-se o marcador mutante (causal da doença) apenas na presença de um conjunto específico de marcadores adjacentes. Ao longo das gerações, no entanto, as recombinações gênicas acabam ocorrendo e o LD verificado gradualmente é dissipado. De fato, o LD depende de $\lambda$ e do número de gerações desde que a mutação foi introduzida na população (Jorde, 1995). Eventos como os movimentos migratórios e a miscigenação, que alteram a distribuição dos alelos em uma população, podem quebrar a relação entre LD e eventos de não-recombinação pois podem conduzir ao LD entre locos distantes (por exemplo, em diferentes cromossomos). Por esta razão, o mapeamento de genes em populações miscigenadas merece cuidados adicionais, como o uso de testes estatísticos protegidos do efeito de resultados falsos positivos.

A busca por regiões de marcadores em LD, envolvendo não apenas pares de locos em desequilíbrio mas análises de multilocos em LD (blocos de SNPs em regiões genômicas com desequilíbrio na distribuição das probabilidades alélicas ou genotípicas), é a base dos métodos de mapeamento genético e o nível do desequilíbrio esperado em uma dada região e em uma dada população serve de base para a interpretação dos estudos de associação, especialmente em estudos que visam o entendimento da arquitetura genética de regulação de doenças. Esses blocos podem conter dois ou mais locos em LD, aumentando a complexidade dos padrões e níveis de LD.

As medidas de desequilíbrio de ligação, considerando análises alélicas e não genotípicas, são largamente utilizadas para montagem de haplótipos (Druet e Georges, 2010), isto é, na reconstru- 
ção dos blocos genômicos localizados em um mesmo cromossomo, mas esta classe de análises está restrita a um primeiro passo de processamento dos dados conhecido como phasing, que transforma dados genotípicos em alélicos. Iniciativas de determinação de haplótipos têm envolvido algoritmos baseados em cadeias de Markov escondidas, HMC - Hidden Markov Chain (Druet e Georges, 2010) e amostragem de Monte Carlo em cadeias de Markov, MCMC - Markov Chain Monte Carlo (Bansal et al., 2008), entre outros (Bourgain et al., 2002). Kim et.al. propôs um modelo baseado em várias cadeias de Markov de múltiplas ordens para particionar o LD de uma região multiloco e a participação de cada possível sub-região no LD total (Kim et al., 2008). Além da associação intra blocos, Greenspam e Geiger utilizaram cadeias de Markov para mostrar que um modelo levando em conta a dependência entre os blocos de marcadores é mais acurado do que os modelos que assumem que os blocos são independentes (Greenspan e Geiger, 2006). Além da necessidade de conhecimento da fase alélica, estes métodos, em geral, assumem blocos de tamanho conhecido e associam tais blocos a uma doença específica.

Os trabalhos e resultados citados evidenciam a complexidade da estrutura do genoma em termos de dependência, bem como sua importância na busca do conhecimento do papel do DNA na evolução da raça humana e sua diversidade. Na seção seguinte será introduzida a questão da ancestralidade e sua relação com a estrutura do genoma.

\subsection{Ancestralidade}

A teoria mais aceita atualmente no que diz respeito à origem do Homo sapiens dá conta que sua migração teve início a partir da África, mais especificamente, na atual Etiópia (Schlesinger, 2010). A discussão das diversas evidências científicas que sustentam essa teoria foge do escopo deste trabalho, contudo, entre elas, está o fato de que, sendo as populações africanas mais antigas, o tempo permitiu um maior número de recombinações gênicas (mistura entre os genes dos pais), levando a haplótipos menores do que aqueles encontrados em populações mais recentes como os europeus e asiáticos. Neste contexto, a população brasileira, formada pela mistura de três populações ancestrais: ameríndias, africanos e europeus, tem uma história relativamente recente de miscigenação. Nas palavras do prof. Sérgio Pena: "Somos mesmo o país da miscigenação. Há brancos que são geneticamente negros e vice versa"(Pena et al., 2000).

A informação transmitida pelos genes nas diversas populações foi largamente estudada por Cavalli-Sforza (Cavalli-Sforza, 1996), tendo, inclusive, proposto um conceito de distância genética entre pares de populações baseado nos genes adquiridos. No padrão do genoma dos indivíduos de hoje, encontramos blocos conservados dos ancestrais, variação no tamanho dos blocos, diferentes mutações distribuídas no genoma, variação na idade das mutações e redução progressiva das dependências devido à recombinação gênica. Uma visão ilustrativa dessa história ancestral das populações pode ser vista na Figura 1.2.

$\mathrm{Na}$ busca do que as populações têm, geneticamente, em comum, os SNPs têm sido utilizados como marcadores importantes para caracterização e determinação da ancestralidade (Nassir et al., 2009; Coelho et al., 2014) e a análise de componentes principais desses marcadores é largamente 


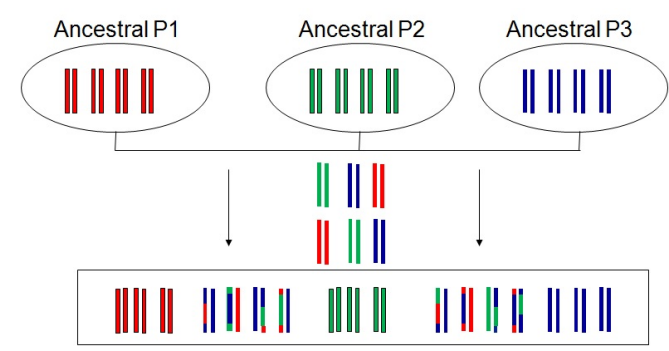

Figura 1.2: História ancestral das populações - uma visão ilustrativa

usada no estudo de populações humanas (Price et al., 2006; Giolo et al., 2012).

\subsection{Objetivos}

A determinação da estrutura de dependência do genoma serve de base para muitos estudos genéticos, especialmente os de mapeamento de genes, isto é, os que procuram associar regiões do genoma a determinada característica observável em um indivíduo (fenótipo). Apesar de existir o efeito de um único SNP na regulação de um determinado fenótipo ${ }^{2}$, tal associação é, por vezes, difícil de encontrar significância estatística, o que se agrava em situações de múltiplos testes. Dada a alta densidade dos SNPs, não poderia haver uma certa influência entre eles? Até onde uma determinada base nitrogenada ( $A, C, T$ ou $G$ ) em um SNP não influencia ou é influenciada pelos outros SNPs ao seu redor? Essas regiões de influência, assim delimitadas, não poderiam ser usadas para caracterizar o genoma de diferentes populações?

Neste contexto, o objetivo deste trabalho é propor uma alternativa utilizando uma abordagem baseada em modelagem estocástica, para estruturar o genoma em regiões dependentes e independentes, tendo como base os genótipos de plataformas de SNPs.

Conforme discutido na seção 1.1, a ligação da dupla hélice do DNA é feita através de pontes de hidrogênio que unem as bases nitrogenadas, mas sempre em pares determinados. Assim, uma adenina $(A)$ sempre se liga a uma timina $(T)$ enquanto que a citosina $(C)$ liga-se sempre com a guanina $(G)$, o que nos permite identificar o par de bases de um loco, em um cromossomo, apenas sabendo uma de suas bases, pois a outra fica determinada pelo par correspondente. Consequentemente, para o genótipo desse loco, ou seja, as bases nitrogenadas dos dois cromossomos homólogos, paterno e materno, basta identificar uma base de cada cromossomo. Quando dizemos, portanto, que o genótipo de um indivíduo em um loco é A-C, na verdade sabemos que em um cromossomo esse loco é composto pelas bases T-A e no outro cromossomo pelas bases C-G. Essa característica química do DNA permite que o genótipo de cada SNP seja codificado utilizando um alfabeto, $A$, restrito, em que $A=\{\mathrm{A}, \mathrm{C}, \mathrm{T}, \mathrm{G}\}$, com $|A|=4$, sendo $|A|$ a cardinalidade do espaço $A$.

Sendo o par $(x, y)$ o genótipo de um SNP, em um loco de um determinado indivíduo, teremos:

$$
(x, y) \in\{\mathrm{A}, \mathrm{C}, \mathrm{T}, \mathrm{G}\}^{2} .
$$

\footnotetext{
${ }^{2}$ Como exemplo, a anemia falciforme é uma doença causada por um único SNP.
} 
Existem algumas alternativas para codificação dos genótipos dos SNPs, as quais serão discutidas no Capítulo 2, por ora, basta compreender que, utilizando uma sequência de SNPs para amostrar o genoma, este pode ser escrito como uma sequência de códigos e ser modelado através de cadeias de Markov, onde cada estado representa os possíveis genótipos de um SNP específico, para assim encontrar as relações de dependência entre SNPs vizinhos.

Considerando uma única população sob estudo, essa abordagem foi utilizada por Leonardi (2007), e devidamente adaptada por Bianchi (2009), de forma a encontrar os SNPs que influenciam e/ou são influenciados por seus vizinhos. Como resultado desse estudo foi possível limitar janelas de SNPs, nas quais há uma relação de dependência entre os SNPs internos e independência dos SNPs externos, constituindo assim uma estruturação para o genoma em regiões dependentes e independentes.

Neste trabalho, utilizou-se essa técnica para levantamento das janelas de SNPs de cada população do projeto HapMap, bem como da amostra da população brasileira (ver Figura 1.3). Denotaremos estas como as "janelas populacionais" específicas de cada população (Jp). Os resultados obtidos foram utilizados para caracterizar as diferentes populações e, consequentemente, suas ancestralidades, conforme suas janelas de influência estimadas dos dados de SNPs.

Estendendo o conceito de influência entre SNPs para a unificação das janelas (populacionais) de cada população propõe-se a construção de janela de consenso maximais (Jc), cada uma contendo as diferentes janelas que se sobrepõem nas diferentes populações. Os resultados deste procedimento são comparados com o que denotaremos como janelas totais (Jt), obtidas supondo-se que os dados das várias populações correspondem a uma amostra de uma única população aumentada, formada pelas várias populações sob estudo. Fazendo uso de uma medida de distância apropriada a variáveis categóricas, é construído um índice de similaridade (IS) e heterogeneidade (IH) para cada janela de consenso, de forma que, janelas de consenso compostas por janelas populacionais muito diferentes entre as populações são mais heterogêneas do que aquelas formadas por janelas mais similares.

Como cada janela de SNPs retrata a estrutura de dependência do genoma, espera-se que janelas de consenso homogêneas entre diferentes populações sejam encontradas em regiões mais conservadas do genoma, em particular, em regiões importantes para a manutenção de nossa espécie, como, por exemplo, a região HLA (Human Leukocyte Antigen), responsável por nossa resposta imunológica. Por outro lado, janelas de consenso heterogêneas podem evidenciar pedaços do genoma no qual as populações diferem entre si e, nos quais, ocorreram mais recombinações.

As janelas da região HLA foram selecionadas e analisadas no que diz respeito à sua homogeneidade. As janelas mais heterogêneas foram utilizadas para construir um classificador baseado em análise de correspondência que foi capaz de identificar em torno de $90 \%$ dos casos, a população originária de um determinado genótipo.

Uma ilustração do racional deste trabalho pode ser vista na Figura 1.4. 


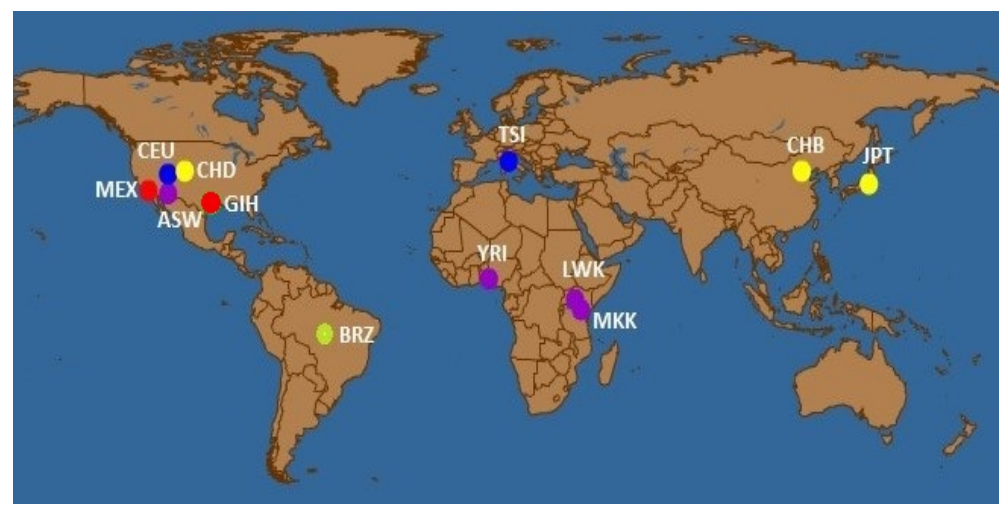

Figura 1.3: Localização geográfica aproximada das populações utilizadas no estudo.

\subsection{Organização do Trabalho}

O presente trabalho foi organizado da seguinte forma: no Capítulo 2 é apresentada a formulação teórica da montagem das janelas de SNPs de cada população em estudo (Jp), enquanto que o Capítulo 3 descreve a proposta de janela de consenso maximal (Jc) de todas as populações, compara este procedimento com a obtenção de janelas totais (Jt), supondo uma única população aumentada formada das diferentes subpopulações, e aborda a caracterização das janelas de consenso, introduzindo a formulação teórica do classificador proposto. No Capítulo 4 são discutidas as janelas populacionais estimadas e seus reflexos em termos de ancestralidade, bem como as janelas de consenso maximais para o conjunto de todas as populações, além da análise da similaridade das janelas de consenso contidas na região HLA do genoma e a proposta de um classificador de ancestralidade utilizando janelas de consenso heterogêneas e os resultados obtidos. Finalmente, no Capítulo 5 são discutidas algumas particularidades deste trabalho e considerações finais indicando trabalhos futuros.

Informações, figuras e tabelas adicionais estão colocadas no Apêndice. 
Dados de SNPs de diferentes populações mundias
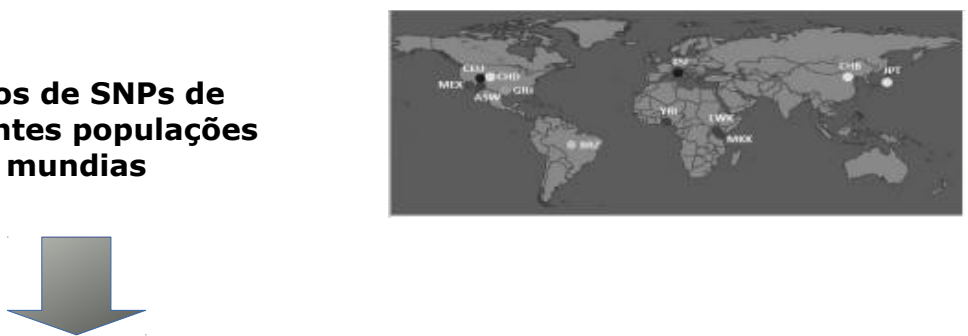

Construção das janelas de dependência para cada população (Jp)


Análise da

ancestralidade de cada população
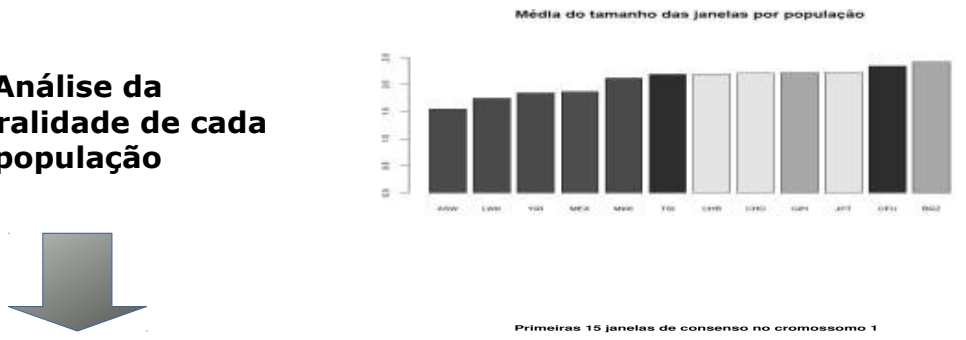

Construção das janelas de consenso maximais

(Jc)
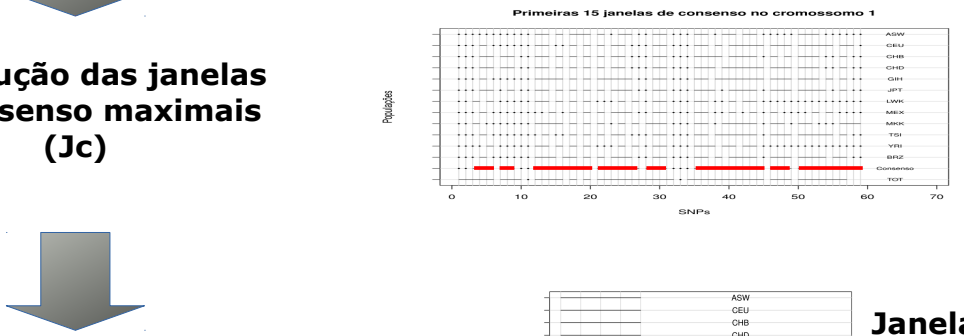

Estudo da Homogeneidade e

Heterogeneidade das janelas de consenso (Jc)

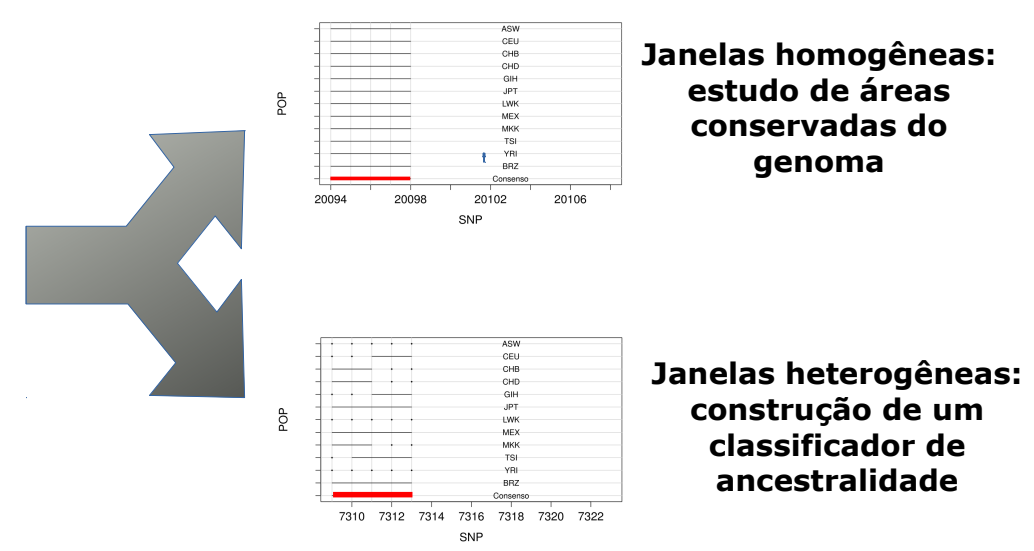

Figura 1.4: Fluxograma das etapas do trabalho 


\section{Capítulo 2}

\section{Modelagem da Estrutura de Dependência do Genoma}

Este capítulo apresenta a formulação da função de verossimilhança e o algoritmo para montagem dos blocos de SNPs, aqui denominados janelas de influência, para cada população sob estudo (Jp). Os resultados apresentados tiveram como base os trabalhos de Leonardi (2007; 2010) e Bianchi (2009). No próximo capítulo, o mesmo conceito é estendido para propor janelas de consenso entre as diferentes populações nas diferentes regiões genômicas, baseadas nas janelas de influência populacionais.

\subsection{Notação}

Conforme discutido no Capítulo 1, simplificadamente, podemos entender o genoma humano como uma sequência linear de bases nitrogenadas (nucleotídeos) de 4 tipos diferentes (A,C,T e G), o que, naturalmente, permite estruturar o genoma como um alfabeto. Somos organismos diplóides, ou seja, nossos cromossomos se organizam em pares de cromossomos homólogos, um proveniente do pai e um da mãe. Em cada cromossomo os nucleotídeos se organizam em pares A-T ou C-G, portanto, precisamos conhecer apenas uma das bases em um cromossomo pois a outra fica determinada pelo par correspondente.

Dessa forma, sabendo uma das bases em cada cromossomo homólogo, temos o genótipo do indivíduo para uma determinada posição no cromossomo, denominada loco. Sendo o par $(x, y)$ o genótipo de um SNP, em um loco de um determinado indivíduo, teremos:

$$
(x, y) \in\{\mathrm{A}, \mathrm{C}, \mathrm{T}, \mathrm{G}\}^{2}
$$

onde: $A=\{\mathrm{A}, \mathrm{C}, \mathrm{T}, \mathrm{G}\}$ é o alfabeto com $|A|=4$ sendo a cardinalidade de $A$.

Dada uma amostra aleatória de tamanho $n$ de genótipos para um determinado SNP, podemos fazer uso de diferentes tipos de codificação. Entre elas, uma muito utilizada especialmente em estudos de associação é a que utiliza 0 para o alelo mais frequente e 1 para o alelo raro. É necessário, portanto, neste caso, dada a amostra, verificar qual a base menos frequente (alelo raro) e atribuir 
Tabela 2.1: Exemplos da codificação adotada para cada SNP.

\begin{tabular}{cccc}
\hline Genótipo & Bases & Codificação Alelos & Codificação SNP \\
\hline A-T C-G & T C & 10 & 1 \\
A-T T-A & T T & 11 & 2 \\
A-T A-T & T A & 11 & 2 \\
C-G G-C & G G & 00 & 0 \\
C-G T-A & G T & 01 & 1 \\
\hline
\end{tabular}

a essa base o valor 1 , deixando o valor 0 para a outra base. Assim procedendo, para cada indivíduo da amostra, codificamos o genótipo do SNP como a soma dos valores dos alelos, assumindo valores no conjunto ternário $\{0,1,2\}$, sendo equivalente ao número de alelos raros encontrados.

Neste trabalho, dado que o conjunto de dados é composto por diferentes populações e as frequências alélicas poderiam ser distintas entre as subamostras populacionais, optou-se por uma codificação fixa, sem perda de generalidade, independentemente da contagem de alelos: as bases $\mathrm{A}$ e $\mathrm{T}$ foram codificadas como 1 e as bases C e G codificadas como 0. Da mesma forma o genótipo fica representado pela soma dos códigos dos alelos. A Tabela 2.1 ilustra alguns exemplos de genótipos e sua correspondente codificação final, na primeira coluna encontra-se o genótipo de um loco para os dois cromossomos homólogos, a segunda coluna extrai uma base de cada cromossomo e as duas últimas colunas são a codificação utilizada.

De acordo com a codificação adotada, cada SNP configura uma variável aleatória cuja realização pertence ao conjunto $\{0,1,2\}$. Assim, para um determinado SNP, em uma posição específica $j$, temos $X_{j}$ a variável aleatória definida como,

$$
X_{j}=x_{j} \quad \mid \quad x_{j} \in\{0,1,2\}
$$

em que,

$$
\left\{\begin{array}{l}
P\left(X_{j}=0\right)=P(\text { genótipo } S N P \in\{\mathrm{CC}, \mathrm{CG}, \mathrm{GC}, \mathrm{GG}\}) \\
P\left(X_{j}=1\right)=P(\text { genótipo } S N P \in\{\mathrm{AC}, \mathrm{AG}, \mathrm{TC}, \mathrm{TG}, \mathrm{CA}, \mathrm{GA}, \mathrm{CT}, \mathrm{GT}\}) \\
P\left(X_{j}=2\right)=P(\text { genótipo } S N P \in\{\mathrm{AA}, \mathrm{AT}, \mathrm{TA}, \mathrm{TT}\})
\end{array}\right.
$$

Um conjunto $S$, de uma sequência de $s$ SNPs será então uma sequência de variáveis aleatórias,

$$
S=\left\{X_{1}, X_{2}, X_{3}, \ldots, X_{s}\right\} \quad \text { sendo }:|S|=s \quad \text { a cardinalidade de } \mathrm{S}
$$

cujas realizações serão do tipo,

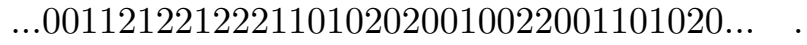

Estendendo a notação para $n$ indivíduos, um determinado SNP na posição $j$ passa a ter uma 
amostra de tamanho $n$ e a variável aleatória $X_{j}$ tem distribuição trinomial

$$
X_{j} \sim \operatorname{Trinomial}\left(\phi_{j}\right) \quad X_{j}=x_{j}^{i} \in\{0,1,2\}
$$

em que: $\left\{\begin{array}{l}j=\text { posição do SNP, } 1 \leqslant j \leqslant s ; \quad s=\text { número total de SNPs na amostra, } \\ i=\text { indivíduo, } 1 \leqslant i \leqslant n ; \quad n=\text { número de indivíduos na amostra, } \\ \phi_{j}=\text { é o vetor de parâmetros da trinomial, } \\ \quad \text { contendo as probabilidades de ocorrências dos valores } 0,1 \text { e } 2 \text {, restritas a somarem } 1 .\end{array}\right.$

Dessa notação, podemos também definir,

$x_{p, q}^{i}=x_{p}^{i} x_{p+1}^{i} \ldots x_{q-1}^{i} x_{q}^{i}, \quad$ com $\quad x_{p, q}^{i} \in\{0,1,2\}^{(q-p+1)} ; \quad 1 \leqslant p \leqslant s ; \quad 1 \leqslant q \leqslant s \quad$ e $\quad p<q$,

como uma sequência de SNPs adjacentes no indivíduo $i$ no intervalo fechado entre as posições $p$ e $q$. Assim, decorre que,

$x_{1, s}^{i} \quad$ é a sequência de todos os SNPs do indivíduo $i$

Uma amostra dos genótipos de $s$ SNPs para $n$ indivíduos será então uma matriz $D_{\left(n_{\times s}\right)}$ e podemos denotar $D_{i .}=x_{1, s}^{i}$ como a linha da matriz $D$ contendo todos os genótipos dos SNPs do indivíduo $i$ e a coluna $D_{. j}$ como sendo as realizações da variável aleatória $X_{j}$ em todos os indivíduos.

\subsubsection{Modelagem por Campos Markovianos}

Cadeias de Markov são, em geral, um tipo de modelagem bastante utilizada para dados com dependência. Como o interesse é encontrar blocos de SNPs que guardam entre si alguma relação de dependência e, considerando cada realização da variável aleatória $X_{j}$ como um estado com distribuição Trinomial, pode-se utilizar a abordagem de cadeias de Markov de ordem $k$ para estimar os parâmetros dessa distribuição. Ocorre que o número de parâmetros para estimação cresce exponencialmente com a ordem $k$, o que pode ser resolvido utilizando cadeias de Markov de alcance variável (Bühlmann et al., 1999), com a diferença importante, no caso do problema aqui colocado, que deve-se inspecionar ambos os lados de um determinado estado (SNP) e não apenas estados anteriores, como mais comumente se verifica na utilização dessa solução. Em outras palavras, o objetivo é encontrar a memória da cadeia de Markov em ambas as direções de um determinado estado.

O problema assim proposto pode ser abordado através da utilização de campos Markovianos ou, mais especificamente, campos Markovianos bidirecionais, os quais, diferentemente das cadeias de Markov tradicionais, onde há uma dimensão temporal (e, consequentemente, um posicionamento relativo de passado-presente-futuro), estuda a vizinhança de cada posição da cadeia, encontrando quantas posições antes e depois são necessárias para determinação da posição em estudo.

Campos Markovianos podem ser interpretados como uma generalização da cadeia de Markov em que, para predizer o estado dentro de uma região finita qualquer, é necessário inspecionar os estados na sua vizinhança (Löcherbach e Orlandi, 2011). Analogamente ao caso unidimensional, essa região 
de vizinhança é denominada região de contexto, sendo assim, uma extensão multidimensional da noção de cadeias de Markov de alcance variável introduzidas por Rissanen em seu artigo clássico (Rissanen et al., 1983).

Utilizando o conceito de contexto, a solução para estimar as probabilidades condicionais associadas ao campo Markoviano será através do algoritmo de árvore de contexto. Para escrever a função de verossimilhança do problema é necessário introduzir o conceito de vizinhança, o que será feito na próxima seção.

\subsubsection{Vizinhança}

Dado um alfabeto $A$ podemos definir uma palavra $w$ de tamanho $m$ como sendo uma sequência de letras desse alfabeto $\left(w \in A^{m}\right)$. Fixada uma posição $j$ dentro da palavra $w, \omega \operatorname{com}|\omega|=l$ será prefixo de $j$ e $\tau$ com $|\tau|=r$, será sufixo de $j$, se $w=\omega j \tau$. Denominamos $\omega$ a vizinhança à esquerda da posição $j$ em $w$ e $\tau$ a vizinhança à direita da posição $j$ em $w$. À concatenação $(\omega \cdot \tau)$ denominamos simplesmente vizinhança de $j$ dentro de $w$.

Usando esse conceito para a sequência de SNPs da amostra, dado um SNP na posição $j$ sua vizinhança será o conjunto:

$$
V_{j}^{l, r}=\{k \in \mathbb{N} \mid j-l \leqslant k \leqslant j+r, k \neq j, j-l \geqslant 1, j+r \leqslant s\},
$$

em que,

$l$ é o número de SNPs vizinhos à esquerda da posição $j$;

$r$ é o número de SNPs vizinhos à direita da posição $j$;

$s$ é o número total de SNPs da unidade amostral.

A partir dessa definição, os valores de $l$ e $r$ determinam o conjunto de dependências entre as variáveis aleatórias que representam os genótipos dos SNPs, em cada posição $j$ específica da amostra, ou seja, dada uma vizinhança $V_{j}^{l, r}$, se $X_{j^{\prime}} \notin V_{j}^{l, r}$ implica que $X_{j}$ é independente de $X_{j^{\prime}}$ dados $X_{k} \mid k \in V_{j}^{l, r}$.

No decorrer deste capítulo, sempre que não houver menção em contrário, designaremos por $j$ a posição de um determinado SNP e por $s$ o total de SNPs dentro de uma unidade amostral, definida neste trabalho como sendo o indivíduo amostrado da população.

\subsection{Função de Verossimilhança}

Dada a matriz $D$ da amostra e considerando os indivíduos (unidades amostrais) independentes, a função de verossimilhança pode ser definida como:

$$
L(\theta \mid D)=\prod_{i=1}^{n} P\left(D_{i .}\right)=\prod_{i=1}^{n} P\left(X_{j}=x_{j}^{i}, \forall j ; 1 \leqslant j \leqslant s\right) .
$$


Num indivíduo $i$, cada SNP é assumido independente condicionalmente ao restante dos SNPs, assim,

$$
L(\theta \mid D)=\prod_{i=1}^{n} \prod_{j=1}^{s} P\left(X_{j}=x_{j}^{i} \mid X_{k}=x_{k}^{i}, \forall k \neq j\right) .
$$

Para a sequência de SNPs, utilizando a definição de vizinhança da seção anterior, podemos utilizar a abordagem introduzida por Besag (Besag, 1975) para a função de pseudo-verossimilhança:

$$
\tilde{L}(\varphi \mid D)=\prod_{i=1}^{n} \prod_{j=1}^{s} P\left(X_{j}=x_{j}^{i} \mid X_{k}=x_{k}^{i}, \forall k \in V_{j}^{l_{j}, r_{j}}\right) .
$$

Assim, assume-se que a distribuição condicional da posição $j$ é especificada em termos de um vetor $\varphi_{j}$ dos parâmetros $\left(l_{j}, r_{j}\right)$ desconhecidos, sendo $l_{j}$ a vizinhança à esquerda e $r_{j}$ a vizinhança à direita da posição $j$. Neste contexto, como a amostra é composta por várias realizações independentes, correspondentes aos diferentes indivíduos na amostra, o processo é denominado não homogêneo, com tamanhos diferentes de vizinhança, dependendo da posição específica $j$. A maximização das expressões $(2.1)$ e $(2.2)$ converge para os mesmos valores e os estimadores $\varphi_{j}=\left(\hat{l}_{j}, \hat{r}_{j}\right)$ são consistentes (Besag, 1975; Bianchi, 2009).

Aplicando então o logaritmo à expressão (2.2), teremos:

$$
\begin{aligned}
& \ell(l, r \mid D)=\log \left(\prod_{i=1}^{n} \prod_{j=1}^{s} P\left(X_{j}=x_{j}^{i} \mid X_{k}=x_{k}^{i}, \forall k \in V_{j}^{l_{j}, r_{j}}\right)\right), \\
& \ell(l, r \mid D)=\sum_{i=1}^{n} \sum_{j=1}^{s} \log \left(P\left(X_{j}=x_{j}^{i} \mid X_{k}=x_{k}^{i}, \forall k \in V_{j}^{l_{j}, r_{j}}\right)\right), \\
& \ell(l, r \mid D)=\sum_{j=1}^{s} \sum_{i=1}^{n} \log \left(P\left(X_{j}=x_{j}^{i} \mid X_{k}=x_{k}^{i}, \forall k \in V_{j}^{l_{j}, r_{j}}\right)\right) .
\end{aligned}
$$

Reescrevendo a probabilidade em termos de prefixos e sufixos, temos:

$$
P\left(X_{j}=a \mid X_{k}=x_{k}^{i}, \forall k \in V_{j}^{l_{j}, r_{j}}\right)=P\left(X_{j}=a \mid X_{j-l}=\omega_{1}, \ldots, X_{j-1}=\omega_{l}, X_{j+1}=\tau_{1}, \ldots, X_{j+r}=\tau_{r}\right)
$$

a qual denotaremos simplesmente por $P_{j}(a \mid \omega, \tau)$. Considerando $N_{j}^{D}(\omega, a, \tau)$ como sendo o número de vezes que o símbolo $a$ aparece na posição $j$, com a vizinhança $\omega$ à esquerda e $\tau$ à direita, dentro da amostra $D_{. j}$, podemos reescrever a equação (2.3) como:

$$
\ell(l, r \mid D)=\sum_{j=1}^{s} \sum_{\omega} \sum_{\tau} \sum_{a}\left(\log \left(P_{j}(a \mid \omega, \tau)\right)^{N_{j}^{D}(\omega, a, \tau)}\right) .
$$

Maximizar a verossimilhança em (2.4), representa maximizar cada parcela da soma em $j$, isto é, considerando cada SNP individualmente. A j-ésima componente da pseudo-verossimilhança em função da vizinhança $(\omega, \tau)$ será,

$$
\left.\ell_{j}(\omega, \tau \mid D)=\sum_{a} N_{j}^{D}(\omega, a, \tau) \log \left(P_{j}(a \mid \omega, \tau)\right)\right)
$$

a qual pode ser definida em termos da distribuição multinomial. Assim, podemos escrever (2.4) na 
forma:

$$
\ell(l, r \mid D)=\sum_{j=1}^{s} \sum_{\omega} \sum_{\tau} \sum_{a}\left(N_{j}^{D}(\omega, a, \tau) \log \left(\frac{N_{j}^{D}(\omega, a, \tau)}{N_{j}^{D}(\omega, ., \tau)}\right)\right),
$$

em que $N_{j}^{D}(\omega, ., \tau)$ corresponde ao número de vezes que a vizinhança $(\omega, \tau)$ aparece na amostra no entorno da posição $j$, para qualquer valor de $X_{j}$. Da forma como está escrita na equação (2.5), a verossimilhança sempre aumenta com o aumento da vizinhança, o que levaria a considerar todos os outros SNPs para maximizar a verossimilhança de uma determinada posição. Portanto , é necessário introduzir um termo de penalização proporcional ao tamanho da vizinhança.

A penalização utilizada é a proposta por Csiszár e Talata (2006), considerando uma constante $c$ dada por $\frac{(|A|-1)}{2}$, onde $A$ é o alfabeto, no nosso caso, $A=\{0,1,2\}$ e um termo proporcional ao tamanho da vizinhança $t(\omega, \tau)=|A|^{|\omega \tau|}$. Finalmente, a expressão da verossimilhança para cada SNP é dada por:

$$
\ell_{j}\left(l_{j}, r_{j} \mid D\right)=\sum_{\omega} \sum_{\tau} \sum_{a}\left(N_{j}^{D}(\omega, a, \tau) \log \left(\frac{N_{j}^{D}(\omega, a, \tau)}{N_{j}^{D}(\omega, ., \tau)}\right)\right)-\frac{(|A|-1)}{2} \cdot|A|^{|\omega \tau|} \log (n) .
$$

A estimação dos parâmetros do modelo é feita calculando a verossimilhança dada por (2.6) para cada vizinhança de uma posição $j$. Os valores $l_{j}$ e $r_{j}$ serão aqueles que a maximizam.

\subsubsection{Algoritmo}

Para estimar os valores de $l_{j}$ e $r_{j}$ que maximizam a expressão (2.6) foi utilizado um programa escrito por Bianchi (2009), em linguagem "C", que utiliza uma estrutura de dados de árvore de vizinhança. A Figura 2.1 representa de forma esquemática um exemplo desse tipo de árvore.

Para cada vizinhança avaliada, é construída uma árvore correspondente. A árvore é percorrida por cada unidade amostral, contabilizando nas folhas o número de vezes que a palavra composta pelos nós foi encontrada. Assim, ao final, cada nó conterá o número de palavras que correspondem ao seu caminho. Como neste caso o alfabeto tem tamanho $3(A=\{0,1,2\}$, logo, $|A|=3)$, mantendo três contadores em cada folha conseguimos contabilizar o número de vezes que cada diferente vizinhança foi encontrada no entorno de cada um dos símbolos do alfabeto.

A profundidade da árvore é então o tamanho de cada vizinhança considerada. Para viabilizar a implementação computacional, foi adotado um limite máximo de tamanho da vizinhança à esquerda e à direita de 20 posições, ou seja, para cada SNP são avaliadas 400 vizinhanças distintas. Tendo em vista essa imposição, deve ser realizada uma validação dos resultados empíricos obtidos, de forma a verificar que essa restrição não comprometeu a estimação dos parâmetros, em outras palavras, os valores estimados de $l$ e $r$, para cada SNP, devem ser sempre bem inferiores ao limite considerado, caso contrário, recomenda-se aumentar o tamanho máximo da vizinhança adotado. Finalmente, a vizinhança estimada para o SNP $j$ será aquela cujos valores $l_{j}$ e $r_{j}$ maximizam a expressão (2.6). 




Figura 2.1: Algoritmo de árvore de contexto: exemplo para uma vizinhança de tamanho 3.

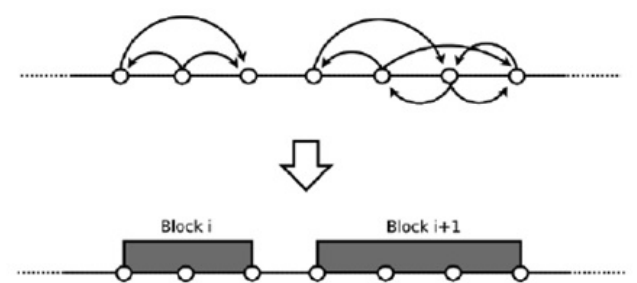

Figura 2.2: Visão esquemática da construção de janelas de influência de SNPs.

\subsubsection{Janelas de Influência}

A vizinhança $V_{j}$ estimada é uma medida da dependência do SNP na posição $j$ em relação aos seus vizinhos à esquerda e à direita. Os parâmetros $l_{j}$ e $r_{j}$ estimados para cada variável $X_{j}$ definem a janela de dependência do SNP na posição $j$. Analogamente, os pares $\left(l_{j-1}, r_{j-1}\right)$ e $\left(l_{j+1}, r_{j+1}\right)$ definem as janelas de dependências dos SNPs vizinhos, nas posições $j-1$ e $j+1$, respectivamente. Avaliando a sobreposição das janelas de dependência dos SNPs adjacentes, podemos definir uma janela de influência $J$ como sendo a sequência de SNPs cujas vizinhanças (janelas de dependência) estão contidas em $J$.

Assim, cada janela de influência $J$ é um par de valores tais que:

$$
J \in\{(a, b) \mid a, b \in\{1, \ldots, s\}, a<b\} \quad e \quad \forall j \in J \Rightarrow V_{j} \subseteq J
$$

A Figura 2.2 ilustra a montagem das janelas de influência; na metade superior estão representados os SNPs adjacentes no forma de pequenos círculos e suas vizinhanças estimadas na forma de arcos; na parte inferior da figura estão representadas as janelas de influência no formato de blocos, formando uma região de SNPs adjacentes que possua suas vizinhanças sobrepostas.

\subsection{Estratificação Populacional}

Conforme descrito na Seção 2.1, bem como na formulação da pseudo-verossimilhança apresentada anteriormente, a matriz de dados $D$ é formada por dados genotípicos de $s$ SNPs avaliados em uma amostra de $n$ indivíduos selecionados aleatoriamente de uma população sob estudo. Neste trabalho, o plano amostral considera a coleta de dados de diferentes populações sob estudo, isto é, as linhas da matriz $D$ estão estratificadas em amostras aleatórias de diferentes populações, assim, consideramos duas diferentes abordagens: 
1. Amostra estratificada (de G populações): neste caso a expressão (2.6) é definida separadamente para cada grupo e os pares $\varphi_{j}^{g}\left(l_{j}^{g}, r_{j}^{g}\right)$ que maximizam a pseudo-verossimilhança em cada SNP $j$ dependerão da amostra relativa ao grupo $g$.

2. Amostra simples (de uma única população): neste caso a expressão (2.6) é definida para $n=\sum_{g=1}^{G} n_{g}$, isto é, assumindo que os dados correspondem a uma amostra (aumentada) de uma única população (heterogênea), e os pares $\varphi_{j}\left(l_{j}, r_{j}\right)$ serão calculados considerando todas as unidades amostrais.

Escrevendo a função de pseudo-verossimilhança para cada um dos casos acima mencionados, teremos, respectivamente:

Caso 1:

$$
\begin{aligned}
\ell_{j}^{g}\left(l_{j}^{g}, r_{j}^{g} \mid D^{g}\right) & =\sum_{\omega} \sum_{\tau} \sum_{a}\left(N_{j}^{D^{g}}(\omega, a, \tau) \log \left(\frac{N_{j}^{D^{g}}(\omega, a, \tau)}{N_{j}^{D g}(\omega, ., \tau)}\right)\right)-\frac{(|A|-1)}{2} \cdot|A|^{|\omega \tau|} \log \left(n_{g}\right) . \\
\text { Caso 2: } & \\
\ell_{j}\left(l_{j}, r_{j} \mid D\right) & =\sum_{\omega} \sum_{\tau} \sum_{a}\left(N_{j}^{D}(\omega, a, \tau) \log \left(\frac{N_{j}^{D}(\omega, a, \tau)}{N_{j}^{D}(\omega, ., \tau)}\right)\right)-\frac{(|A|-1)}{2} \cdot|A|^{|\omega \tau|} \log (n) .
\end{aligned}
$$

Analisando as expressões (2.7) e (2.8), verificamos que, se para cada SNP (ou posição $j$ ), as amostras de cada grupo (população), separadamente, e da amostra total, forem originadas a partir de uma mesma distribuição trinomial, os parâmetros de vizinhança estimados nos dois casos serão os mesmos.

Neste estudo, consideramos empiricamente as duas abordagens e, como esperado, em geral, os pares $\varphi_{j}^{g}$ e $\varphi_{j}$ foram diferentes, determinando diferentes vizinhanças e, consequentemente, janelas de influência distintas, evidenciando estruturas de dependência dentro do genoma específicas para cada população de estudo.

\subsection{Janelas de Consenso}

Considerando amostras estratificadas de acordo com os diferentes grupos populacionais sob estudo, seja $J p$ a janela de influência estimada considerando os dados de cada população. Unificando as estimativas das várias populações, propomos a formação de uma nova janela, a qual definiremos como janela de consenso, denotada po $J c$, generalizando o mesmo conceito utilizado para encontrar as janelas de influência dos SNPs, desta vez, sobrepondo as janelas de influência de cada população, em cada região específica do genoma.

Cada janela de influência estimada em uma população representa um conjunto de SNPs que guardam entre si uma relação de dependência. Para cada intervalo de SNPs adjacentes é possível verificar se existem ou não janelas de influência parcial ou totalmente inseridas nesse intervalo, em cada uma das populações em estudo. Assim, podemos definir a janela de consenso $J c$ como sendo uma sequência de SNPs na qual existem janelas de influência que estão contidas em $J c$. 




Figura 2.3: Esquema ilustrando a construção de uma janela de consenso maximal.

Portanto, cada janela de consenso $J c$ é um par de valores tais que:

$$
J c \in\{(c, d) \mid c, d \in\{1, \ldots, s\}, c<d\} \quad e \quad \forall J p \in J c \Rightarrow J p \subseteq J c
$$

mais especificadamente, se houverem $K$ janelas de influência contidas em uma janela de consenso $J c$, teremos:

$J_{p}=\left(a_{p}, b_{p}\right), 1 \leqslant p \leqslant K, \quad$ se $\quad J_{p} \subseteq J_{c} \Rightarrow\left(c \leqslant a_{p} \quad e \quad d \geqslant b_{p}\right), \quad \forall p, \quad 1 \leqslant p \leqslant K, \quad 1 \leqslant K \leqslant G$,

com $G$ sendo o número de populações sob estudo. A Figura 2.3 mostra esquematicamente a montagem de uma janela de consenso maximal, em uma região específica do genoma, neste caso, um intervalo de 5 SNPs: cada linha representa um estrato, isto é, uma população, os pontos são SNPs independentes, os blocos pretos as janelas populacionais $(J p)$ e a janela de consenso $(J c)$, está evidenciada na cor vermelha.

A janela de consenso assim definida, $J c$, pode servir, portanto, como uma medida da heterogeneidade das regiões de dependência entre as populações. De fato, caso as expressões (2.7) e (2.8) forneçam as mesmas estimativas, podemos esperar que as janelas de consenso maximais, $J c$, assim construídas, e as janelas de influência determinadas a partir da amostra total sem considerar a estratificação (caso 2), denotada como $J$ t, sejam iguais. 


\section{Capítulo 3}

\section{Caracterização das Janelas de Consenso e Classificação das Observações}

A definição de uma região de consenso entre várias amostras de DNA não é simples e requer que critérios sejam estabelecidos. De maneira intuitiva, uma região de consenso é aquela formada pelas bases que mais aparecem juntas quando os genomas são alinhados. Adequando essa definição para o caso de amostras estratificadas, que é o escopo deste estudo, uma janela de consenso seria aquela formada a partir da comparação entre as janelas das amostras, neste caso, entre as janelas de influência obtidas para cada população $(J p)$. Nesta comparação, a janela de consenso proposta no Capítulo 2 seguiu o princípio maximal.

Alternativamente, poder-se-ia propor um modelo de janela de consenso minimal. Neste caso, uma janela de consenso entre dois SNPs existiria apenas se as respectivas janelas de influência em todas as populações também existissem. Essa abordagem pode ser útil para algumas finalidades, como na identificação de pontos em que o genoma mais sofreu cortes (possivelmente, recombinações) ao longo da evolução. Contudo, neste trabalho, considerando que o objetivo é determinar regiões de dependência do genoma, a janela maximal é considerada mais adequada, sendo a generalização do processo utilizado para cada população individualmente, quando da determinação das janelas de influência.

\section{1 Índice de Heterogeneidade (IH)}

Com a finalidade de caracterização das janelas de consenso, estas podem ser resultados de regiões do genoma bastante diferentes em termos das janelas de influência de cada população ou, ao contrário, de segmentos do genoma nos quais as janelas de influência são muito parecidas ou até mesmo iguais entre as populações, o que, intuitivamente, leva a classificá-las em termos de sua homogeneidade/heterogeneidade. A Figura 3.1 ilustra os dois $\operatorname{casos}^{1}$. No primeiro deles (figura A), na região da janela de consenso encontramos grande variabilidade das janelas de influência, tendo desde populações com janelas iguais à de consenso até populações nas quais todos os SNPs da região são independentes de sua vizinhança. Por outro lado, a figura B, mostra uma janela de consenso

\footnotetext{
${ }^{1}$ Em particular, a figura mostra duas regiões encontradas de fato no cromossomo 6 .
} 
formada por janelas rigorosamente iguais em todas as populações.



A

Figura 3.1: A) Exemplo de uma janela de consenso heterogênea (região correspondente aos SNPs nas posições 7310 a 7314 no cromossomo 6); B) Exemplo de janela de consenso homogênea (região correspondente aos SNPs posicionados de 20095 a 20099 no cromossomo 6).

Para avaliar a heterogeneidade de uma determinada janela de consenso é preciso quantificar a distância entre as janelas de influência formadoras da mesma. Para isso utilizou-se o conceito de medida de distância/similaridade entre variáveis categóricas. O processo é explicado nos passos a seguir:

1. Para cada janela de consenso, as respectivas janelas de influência de cada população são codificadas em uma sequência de números binários, sendo 1 para os intervalos entre SNPs que pertencem a uma mesma janela de influência e 0 para os intervalos entre SNPs que pertencem a janelas de influência distintas. Cada janela de influência fica agora representada por uma cadeia binária de comprimento igual ao tamanho da janela de consenso menos 1 . Por esse motivo, no cálculo do índice de heterogeneidade, janelas de consenso de tamanho unitário são descartadas, contudo, lhes é atribuído valor máximo de similaridade pois, na verdade, nestes casos, todas as janelas de influência são iguais e representadas por um único SNP independente;

2. Considerando agora cada intervalo entre SNPs codificado como uma variável categórica binária é possível calcular a distância entre as populações duas a duas e construir uma matriz de similaridade/dissimilaridade entre as populações. Neste trabalho, a distância Euclidiana ao quadrado média foi adotada como medida de dissimilaridade entre pares de populações. Esta medida assume valores entre 0 e 1 e, portanto, seu complemento é uma medida de similaridade;

3. Finalmente, a partir da matriz de dissimilaridades é calculado um valor médio fornecendo um Índice de Heterogeneidade (IH), com valor entre 0 e 1 . O complemento dessa medida equivale ao Índice de Similaridade (IS) adotado.

O procedimento descrito acima pode ser melhor entendido a partir de um exemplo hipotético, como o mostrado na Figura 3.2. Neste caso avaliamos uma região genômica correspondente a uma janela de consenso de 7 SNPs em 5 populações distintas. No primeiro quadro, representa-se as janelas de influência de cada população na janela de consenso; o quadro abaixo é a transcrição dessas 

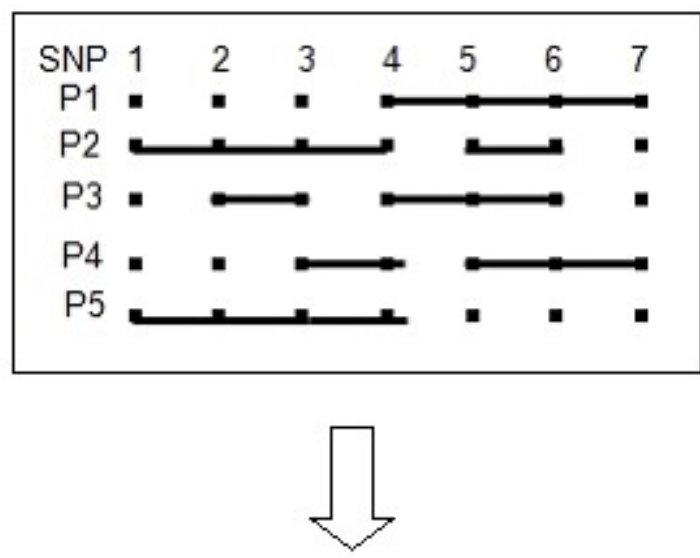

\begin{tabular}{ccccccc}
\hline & SNP1_2 & SNP2_3 & SNP3_4 SNP4_5 & SNP5_6 & SNP6_7 \\
\hline P1 & 0 & 0 & 0 & 1 & 1 & 1 \\
P2 & 1 & 1 & 1 & 0 & 1 & 0 \\
P3 & 0 & 1 & 0 & 1 & 1 & 0 \\
P4 & 0 & 0 & 1 & 0 & 1 & 1 \\
P5 & 1 & 1 & 1 & 0 & 0 & 0 \\
\hline
\end{tabular}

\begin{tabular}{c|cc|c}
\hline & \multicolumn{2}{|c|}{$\mathrm{P} 2$} & \\
$\mathrm{P} 1$ & 1 & 0 & Total \\
\hline 1 & 1 & 2 & 3 \\
0 & 3 & 0 & 3 \\
\hline Total & 4 & 2 & 6 \\
\hline
\end{tabular}

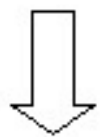

\begin{tabular}{c|ccccc} 
holht & 1 & 2 & 3 & 4 & 5 \\
\hline 1 & 1 & $5 / 6$ & $1 / 3$ & $1 / 3$ & 1 \\
2 & $1 / 6$ & 1 & $1 / 2$ & $1 / 2$ & $1 / 6$ \\
3 & $2 / 3$ & $1 / 2$ & 1 & $2 / 3$ & $2 / 3$ \\
4 & $2 / 3$ & $1 / 2$ & $1 / 3$ & 1 & $2 / 3$ \\
5 & 0 & $5 / 6$ & $1 / 3$ & $1 / 3$ & 1
\end{tabular}

Figura 3.2: Exemplo hipotético para ilustrar o procedimento de cálculo dos índices de heterogeneidade (IH) e similaridade (IS)

janelas em sequências binárias, tendo ao lado o cálculo da distância Euclidiana média entre a primeira e segunda populações (P1 e P2). A matriz no final é a matriz de similaridade/dissimilaridade calculada para todas as comparações entre pares de populações. Nessa matriz, a triangular superior refere-se às dissimilaridades e a triangular inferior (em destaque na figura), incluindo a diagonal principal, refere-se às similaridades.

Ainda utilizando o exemplo da Figura 3.2, a distância entre as populações 1 e 2 é calculada como:

$$
\bar{d}_{1,2}=\frac{(2+3)}{6}=\frac{5}{6},
$$

ou seja, a soma da diagonal secundária da tabela dividida pelo total de intervalos e, analogamente, a similaridade entre essas duas populações será a soma da diagonal principal dividida pelo total de intervalos.

$$
\bar{s}_{1,2}=\frac{(1+0)}{6}=\frac{1}{6} .
$$

Uma vez construída a matriz de similaridade/dissimilaridade, o índice de heterogeneidade (IH) 
é calculado somando-se os elementos da triangular superior, ou seja, a soma de todas as dissimilaridades e normalizando pelo número de comparações pareadas entre as populações. O IH calculado para uma janela de consenso $l$ qualquer $\left(J c_{l}\right)$, em $G$ populações será,

$$
\mathrm{IH}_{J c_{l}}=\sum_{g, g^{\prime}=1 ; g<g^{\prime}}^{G} \frac{\bar{d}_{g g^{\prime}}}{m_{l}} \quad \text { sendo, } \quad m_{l}=\frac{G(G-1)}{2} .
$$

Voltando ao exemplo da Figura 3.2, o IH calculado seria: $\mathrm{IH}=\frac{\frac{17}{3}}{10}=0,57$. O índice de similaridade (IS) é complementar ao IH, logo,

$$
\mathrm{IS}_{l}=1-\mathrm{IH}_{l}
$$

\subsection{Classificador}

Sendo as janelas de consenso resultantes de um processo de unificação maximal das janelas de influência e estas, por sua vez, retratando a estrutura de dependência de uma determinada região, em uma determinada população, qual seria a interpretação da classificação dessas janelas em função do seu IH? Pode-se propor duas hipóteses de estudo: a presença de uma janela de consenso homogênea deve estar associada a regiões mais conservadas do genoma humano, regiões nas quais a homogeneidade pode ser necessária para preservação, enquanto que as janelas de consenso heterogêneas podem indicar regiões de diversidade das populações mundiais, refletindo assim divergências em suas histórias ancestrais.

Se janelas heterogêneas acabam por refletir áreas de dependência entre os SNPs que são discriminantes das diferentes populações, estas podem, então, ser utilizadas para identificar, a partir dos genótipos dos SNPs correspondentes, a população originária de um determinado indivíduo, ou ainda, a proporcionalidade de contribuições ancestrais de cada população, configurando assim um classificador.

Para cada janela heterogênea existem diferentes genótipos com frequências que variam entre as populações do estudo. Uma tabela de contingência construída a partir das populações (linhas) e dos diferentes genótipos (colunas) pode sintetizar essas informações. A Tabela 3.1 foi retirada de Greenacre (2007) mas pode perfeitamente ilustrar a representação do que seria a distribuição de 3 diferentes genótipos em uma janela de consenso para 5 diferentes populações. Assim, dado um determinado genótipo para uma dada janela de consenso (ou seja, condicionando uma coluna da tabela), representando o indivíduo que se deseja classificar, a população mais provável para este indivíduo será aquela na qual o genótipo dado é relativamente mais frequente. O problema assim colocado passa a ser multivariado no sentido de relacionar as linhas e colunas da tabela com a distribuição de genótipos entre as populações sob estudo. Uma técnica capaz de lidar com esse tipo de abordagem em tabelas de contingência é a Análise de Correspondência (Greenacre, 2007). 
Tabela 3.1: Tabela de contingência hipotética representativa de uma janela contendo 3 diferentes genótipos (G1, G2, G3) em 5 populações (P1, P2, P3, P4, P5). Valores entre parênteses são as frequências relativas.

\begin{tabular}{cccc|c}
\hline Populações & G1 & G2 & G3 & Total \\
\hline P1 & 5 & 7 & 2 & 14 \\
& $(0,357)$ & $(0,500)$ & $(0,143)$ & \\
P2 & 18 & 46 & 20 & 84 \\
& $(0,214)$ & $(0,548)$ & $(0,238)$ & \\
P3 & 19 & 29 & 39 & 87 \\
& $(0,219)$ & $(0,333)$ & $(0,448)$ & \\
P4 & 12 & 40 & 49 & 101 \\
& $(0,119)$ & $(0,396)$ & $(0,485)$ & \\
P5 & 3 & 7 & 16 & 26 \\
& $(0,116)$ & $(0,269)$ & $(0,615)$ & \\
\hline Total & 57 & 129 & 126 & 312 \\
Perfil médio & $(0,183)$ & $(0,413)$ & $(0,404)$ & \\
\hline
\end{tabular}

\subsubsection{Análise de Correspondência - Representação Gráfica}

A análise de correspondência $(\mathrm{AC})$ é uma técnica exploratória, particularmente útil para analisar as associações entre variáveis categorizadas dispostas em uma tabela de contingência (Greenacre, 2007), sendo denominada análise de correspondência simples (ACS) quando a tabela é de dupla entrada, como é o caso do presente estudo. Fazendo uso de medidas de correspondência entre linhas e colunas, a ACS propõe uma visão geométrica das associações entre as variáveis, através de um gráfico em dimensão reduzida (em geral, no plano), que permite a visualização do padrão de associação entre os níveis das variáveis definidas na linha e coluna da tabela. Por se tratar de uma técnica multivariada, é capaz de evidenciar associações que eventualmente não apareceriam se fossem analisadas apenas as relações entre pares dos níveis das variáveis. De modo geral, a análise de correspondência trata da montagem de mapas bidimensionais nos quais as linhas e colunas são representadas e, dependendo de como são calculadas as coordenadas, as distâncias entre essas representações podem ser interpretadas como uma medida de similaridade entre linhas, similaridade entre colunas ou associação entre linhas e colunas.

Ao analisarmos os perfis linha ou coluna de frequências relativas de uma tabela de contingência, acabamos por impor uma nova restrição: a soma das proporções obtidas em cada linha, nos perfis linha, deve ser unitária e, analogamente, a soma das proporções das colunas também deve ser unitária, para a tabela de perfis coluna. Assim, a representação de uma tabela de contingência com $i$ categorias diferentes nas linhas e $j$ categorias diferentes nas colunas, pode ser feita perfeitamente, isto é, sem perda de informação, em um plano de dimensão $k$ igual ao mínimo entre $(i-1)$ e $(j-1)$, um subespaço $k$-dimensional denominado simplex. A Figura 3.3 mostra a representação, em duas dimensões, dos perfis linha dos dados da Tabela $3.1 \mathrm{em}$ coordenadas triangulares, na qual cada vértice representa um dos 3 diferentes genótipos ou, em outras palavras, um perfil linha fictício que contém 100\% dos casos concentrados em um único genótipo (coluna), assim, o vértice G1, por exemplo, corresponde a um perfil linha igual a $(1,0,0)$.

Como a técnica de análise de correspondência é utilizada em grande parte de forma descritiva para finalidade de visualização de padrões de associação, quando as variáveis têm dimensão mínima 


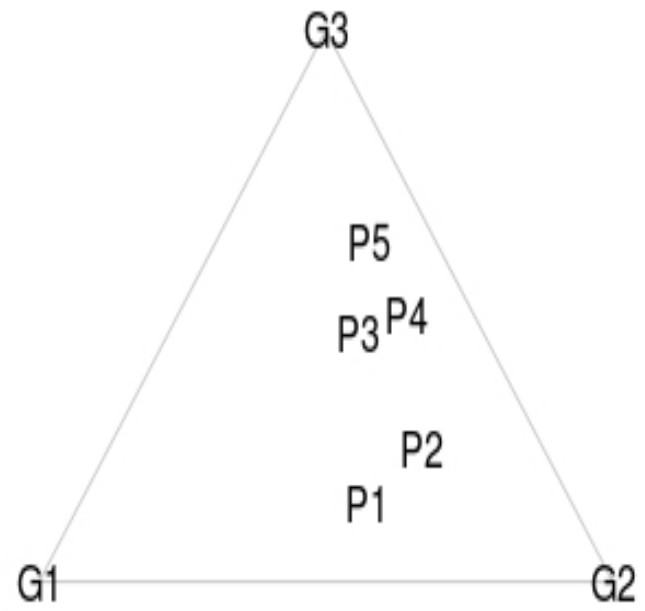

Figura 3.3: Gráfico mostrando os perfis linha da Tabela 3.1 em coordenadas triangulares

maior que 4, a representação gráfica perfeita seria impossível. Nestes casos, uma redução de dimensionalidade é realizada com a obtenção de um mapa ${ }^{2}$ bidimensional, resultante de uma projeção na qual a perda de informação seja mínima, ou seja, que a proporção da inércia total representada pelos dois primeiros eixos seja a maior possível.

Para o classificador proposto, não seria viável analisar visualmente cada associação genotípica com uma população em cada diferente janela de consenso, sem mencionar que a perda de informação poderia ser importante em janelas com muitos genótipos diferentes ${ }^{3}$. No entanto, podemos usar a capacidade de representação da ACS e calcular a população mais próxima de um dado genótipo através de medidas de distância adequadas, utilizando todas as dimensões possíveis, atribuindo o indivíduo para a população na qual essa distância é mínima.

Uma explicação mais detalhada da elaboração dos mapas de análise de correspondência fugiria do objetivo deste capítulo, contudo, algumas considerações importantes dessa técnica precisam ser mencionadas. A primeira delas diz respeito ao tipo de distância utilizada, que, neste caso, é a distância qui-quadrado $\left(\chi^{2}\right)$, distância que também serve como base para o cálculo da estatística de mesmo nome, muito utilizada para testes de associação em tabelas de contingência. A distância $\chi^{2}$ é um exemplo de distância Euclidiana ponderada, na qual os pesos são o inverso dos elementos dos perfis médios, o que remove o efeito de escala e, consequentemente, faz as contribuições de cada categoria mais similares (Greenacre, 2007). Assim, a distância $\chi^{2}$ entre perfis é, na verdade, a distância Euclidiana em um espaço Euclidiano com novas coordenadas.

Dentre os possíveis mapas de representação da AC, um deles é o chamado "mapa assimétrico". Recebe este nome porque, apesar de representar linhas e colunas num mesmo espaço Euclidiano, as linhas e colunas são representadas em coordenadas diferentes. No caso do mapa assimétrico de

\footnotetext{
${ }^{2}$ Como usado em Greenacre (2007), aqui nomeamos o gráfico de dispersão como mapa pois os eixos representarão variáveis de mesma natureza e escala comparáveis, no qual a distância entre pontos pode ser interpretada como uma medida de dissimilaridade.

${ }^{3}$ Neste estudo, como temos 12 populações, o número máximo de dimensões do mapa simétrico da ACS é 11, mesmo quando existem mais do que 12 genótipos diferentes na janela.
} 
linhas, estas são representadas em coordenadas principais, enquanto que as colunas, são representadas por coordenadas padronizadas ${ }^{4}$. Nesse mapa as colunas são os vértices, funcionando como referência e a distância Euclidiana entre os perfis linha corresponde à distância $\chi^{2}$ entre eles. A mesma análise pode ser feita, analogamente, para o mapa assimétrico de colunas.

Os mapas assimétricos são muito úteis quando o objetivo é comparar perfis de linha ou perfis de coluna separadamente, contudo, para medir distância entre linha e coluna, ele não é adequado por conta da diferença de escala entre linhas e colunas na sua construção, apesar da posição relativa entre perfis e vértices se manter (Greenacre, 2007). Transpondo para o caso deste trabalho, dada uma determinada janela de consenso, um mapa assimétrico de linhas seria ideal para, por exemplo, verificar quais as duas populações mais próximas ou, alternativamente, encontrar quais os genótipos mais similares entre todas as populações, utilizando um mapa assimétrico de colunas.

Uma alternativa para o problema de escala é o mapa simétrico, o mais comumente encontrado em trabalhos de AC, no qual ambas linhas e colunas são representadas em coordenadas principais. Num mapa simétrico, as configurações separadas dos perfis linha e coluna são sobrepostas em um mapa comum, apesar de, estritamente falando, serem provenientes de espaços Euclidianos diferentes. Nesse tipo de mapa, as distâncias entre linhas e as distâncias entre colunas são aproximadamente as distâncias $\chi^{2}$ entre os respectivos perfis, porém, a distância entre linhas e colunas não está bem definida e, portanto, deve ser interpretada com ressalvas (Greenacre, 2007).

Apesar de um estudo de bondade de ajuste comparativo entre os mapas simétricos e outros mapas ter concluído que, em muitas aplicações, é razoável usar o mapa simétrico (Gabriel, 2002), como o objetivo do caso em estudo é verificar a menor distância entre um determinado genótipo e as diferentes populações, optou-se por um tipo de mapa mais rigoroso neste sentido, o qual será discutido na próxima seção.

\subsubsection{Mapa Biplot}

O mapa Biplot, é uma alternativa mais acurada para juntar linhas e colunas numa mesma representação. É uma abordagem baseada em produto escalar entre os vetores linha e os vetores coluna. A ideia por trás é encontrar os pontos linha $x_{i}$ e coluna $y_{j}$ tais que o produto escalar entre os vetores linha e coluna recuperem os elementos da matriz (Greenacre, 2007). Assim, os dados $t_{i j}$ são a soma do produto escalar no subespaço $K$-dimensional,

$$
t_{i j}=\sum_{k=1}^{K} x_{i k} y_{j k}
$$

Para compreender a relação entre esse tipo de mapa Biplot e a AC é preciso introduzir a expressão de reconstituição dos dados originais de uma tabela de contingência em termos das massas ${ }^{5}$ e coordenadas de linhas e colunas.

\footnotetext{
${ }^{4}$ A obtenção dessas coordenadas pode ser feita a partir da decomposição espectral singular da matriz de proporções.

${ }^{5}$ Massa da linha/coluna é o vetor obtido pela divisão dos totais de cada linha/coluna pelo total geral.
} 
Fórmula de reconstituição:

$$
p_{i j}=r_{i} c_{j}\left(1+\sum_{k=1}^{K} \phi_{i k} \gamma_{j k}\right)
$$

em que,

- $p_{i j}$ são as proporções relativas em cada posição da tabela $\left(p_{i j}=\frac{n_{i j}}{n}\right), n_{i j}$ sendo o valor da tabela na linha $i$ e coluna $j$ e $n$ sendo a soma total dos valores da tabela)

- $r_{i}$ e $c_{j}$ são as massas das linhas e colunas

- $\phi_{i k}$ e $\gamma_{j k}$ são as coordenadas principais das linhas e padronizadas das colunas, respectivamente.

A expressão (3.1) pode ser reescrita sob o ponto de vista de perfil linha como:

$$
\left(\frac{p_{i j}}{r_{i}}-c_{j}\right) / c_{j}=\sum_{k=1}^{K} \phi_{i k} \gamma_{j k}
$$

Neste tipo de mapa Biplot, as colunas serão representadas como vetores, sendo de interesse a direção desses vetores, pois é nessa direção que os perfis linha serão projetados. Greenacre (2007) propõe uma variação da expressão (3.2), dada por,

$$
\left(\frac{p_{i j}}{r_{i}}-c_{j}\right) / c_{j}^{1 / 2}=\sum_{k=1}^{K} \phi_{i k}\left(c_{j}^{1 / 2} \gamma_{j k}\right) .
$$

Nesta proposta, o lado esquerdo da equação é um desvio padronizado da média e o termo $c_{j}^{1 / 2}$ é absorvido nas coordenadas das colunas, no lado direito. O efeito disso no mapa é diminuir o tamanho dos vetores dos vértices, aproximando-os do centro do mapa e, consequentemente, aumentando a legibilidade da representação. No caso deste trabalho, como a análise será em termos de distância e não simplesmente para visualização das associações, essa melhora na representação não é crucial, contudo, esta foi a variação do Biplot adotada para a definição de nosso classificador. Como os valores representados estão padronizados, esta proposta é chamada de Biplot padrão para AC.

Vale ressaltar que não há como afirmar qual a melhor representação bidimensional para uma análise de correspondência, uma vez que diversos mapas são igualmente passíveis de interpretação. No entanto, além da argumentação teórica proposta por Greenacre (2007) em favor do mapa Biplot, no que diz respeito à precisão para medida de distância entre os pontos representativos de linhas e colunas, os resultados empíricos do classificador, utilizando diversas alternativas de mapas, entre eles, mapas assimétricos e simétricos, foram sempre inferiores àqueles obtidos quando o mapa Biplot padrão foi utilizado ${ }^{6}$.

\footnotetext{
${ }^{6}$ Os resultados obtidos pelo classificador utilizando os outros tipos de mapa não estão apresentados neste trabalho.
} 


\section{Capítulo 4}

\section{Aplicação - Análise das Janelas de Influência na História Ancestral das Populações}

\subsection{Preparação e Descrição dos Dados Utilizados no Estudo}

Este trabalho fez uso do arquivo de dados utilizado por Giolo et al. (2012), resultado da fusão dos arquivos de dados do projeto HapMap (disponível em http://www.sanger.ac.uk/humgen/hapmap3) e da amostra da população brasileira (Projeto Trios de São Paulo, disponibilizado pelo Laboratório de Cardiologia e Genética Molecular, InCor/USP). Ambos os arquivos estavam no formato .ped e .map, compatíveis com o conjunto de ferramentas de análise disponíveis no programa PLINK (Purcell et al., 2007), um recurso poderoso e comumente utilizado no processamento de dados genômicos. O arquivo final resultou em um conjunto de dados contendo 365.116 SNPs comuns às 12 populações, distribuídos pelos 22 pares cromossômicos ${ }^{1}$ conforme a Figura $4.1 .^{.}$

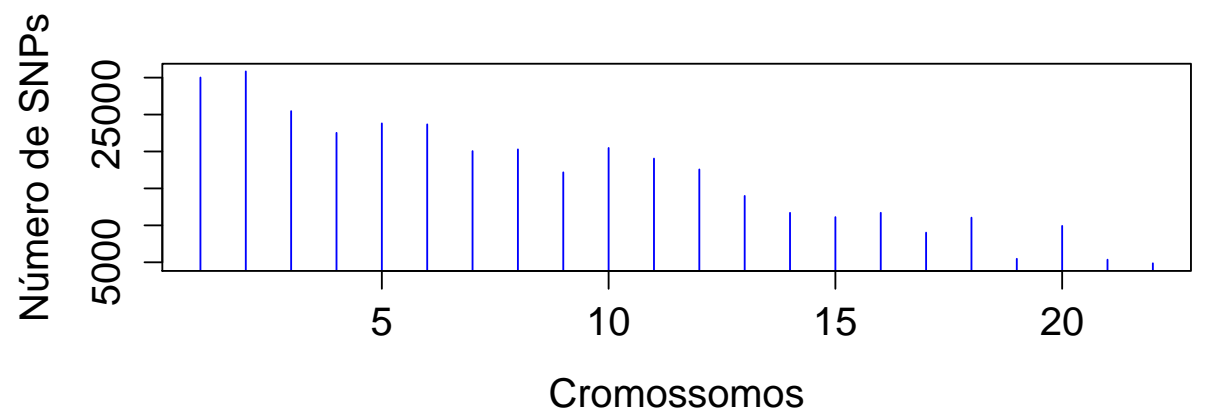

Figura 4.1: Distribuição dos 365.116 SNPs comuns às populações ao longo dos 22 cromossomos somáticos.

Conforme discutido no Capítulo 2, a metodologia proposta para a determinação das janelas de influência, pressupõe a independência dos dados amostrais. Satisfazendo essa condição, o arquivo

\footnotetext{
${ }^{1}$ A célula humana é composta por 23 pares de cromossomos sendo 1 par de cromossomos sexuais (que determinam o sexo) e 22 pares denominados somáticos. Este estudo restringiu-se apenas aos cromossomos somáticos.
} 
final contém apenas os fundadores ${ }^{2}$ presentes em cada população. A Tabela 4.1 mostra os dados considerados no estudo, ou seja, apenas os indivíduos independentes para cada população.

O algoritmo proposto no Capítulo 2, implementado na linguagem C por Bianchi (2009), exige que o arquivo de entrada esteja em um formato pré-determinado. A etapa de preparação foi, portanto, a montagem do arquivo segundo esse formato de entrada exigido e a re-codificação dos SNPs. O arquivo no formato .ped está organizado em uma linha para cada indivíduo da amostra, estando os genótipos nas colunas; o arquivo de entrada do algoritmo proposto, ao contrário, deve ser organizado com um SNP por linha e os genótipos dos indivíduos em colunas. O comando do programa PLINK que executa essa transposição está colocado abaixo (neste comando, o rótulo 'TOT' deve ser substituído pelo arquivo populacional desejado).

$1 . /$ plink - -file TOT --recode --alleleACGT - transpose - -tab - - out tTOT

Finalmente, para codificação dos genótipos dos SNPs, foi implementada uma rotina na linguagem perl, utilizando-se o valor 1 para as bases nitrogenadas A ou T (adenina e timina) e o valor 0 para as bases C ou G (citosina ou guanina), conforme descrito no Capítulo 2. O código fonte dessa rotina está disponível no Apêndice A.1.1.

Tabela 4.1: Populações amostradas e número de indivíduos considerados no estudo

\begin{tabular}{llc}
\hline Rótulo & População Amostrada & Fundadores \\
\hline ASW & população do sudoeste dos EUA com ancestralidade africana & 47 \\
CEU & residentes de Utah com ancestralidade do norte e ocidente da Europa & 112 \\
CHB & chineses em Beijing, China, com ancestralidade da dinastia Han & 84 \\
CHD & chineses residentes na área metropolitana de Denver, Colorado & 85 \\
GIH & índios Gujarati em Houston, Texas & 88 \\
JPT & japoneses em Tokyo, Japão & 86 \\
LWK & residentes em Webuye, Quênia com ancestralidade Luhya & 90 \\
MEX & residentes em Los Angeles, Califórnia com ancestralidade mexicana & 50 \\
MKK & residentes em Kinyawa, Quênia com ancestralidade Maasai & 143 \\
TSI & residentes próximos a Florência, Itália com ancestralidade toscana & 88 \\
YRI & residentes em Ibadan, Nigéria com ancestralidade Yoruba & 113 \\
BRZ & brasileiros da região urbana de São Paulo & 138 \\
\hline TOT & todos os indivíduos & 1124 \\
\hline
\end{tabular}

\footnotetext{
${ }^{2}$ Por conveniência e de maneira geral, denominam-se fundadores os indivíduos marcados como pai e mãe em uma determinada família e, consequentemente, pressupõem-se independentes geneticamente.
} 
Tabela 4.2: Número de SNPs e as Janelas obtidas por população para cada cromossomo

\begin{tabular}{|c|c|c|c|c|c|c|c|c|c|c|c|c|c|c|}
\hline \multirow[t]{2}{*}{ Cromossomo } & \multirow[b]{2}{*}{ SNP } & \multicolumn{13}{|c|}{ Janelas Encontradas } \\
\hline & & ASW & $\mathrm{CEU}$ & CHB & CHD & GIH & JPT & LWK & MEX & MKK & TSI & YRI & BRZ & TOT \\
\hline 1 & 30011 & 18919 & 12512 & 13362 & 13271 & 13198 & 13145 & 16843 & 15718 & 13924 & 13473 & 15980 & 12155 & 5718 \\
\hline 2 & 30841 & 19838 & 12993 & 13910 & 13788 & 13670 & 13742 & 17482 & 16287 & 14263 & 13899 & 16536 & 12510 & 5927 \\
\hline 3 & 25464 & 16441 & 10893 & 11729 & 11615 & 11423 & 11533 & 14538 & 13574 & 12043 & 11603 & 13844 & 10483 & 4922 \\
\hline 4 & 22523 & 14456 & 9569 & 10147 & 10106 & 10163 & 10072 & 12836 & 11880 & 10519 & 10161 & 12140 & 9226 & 4395 \\
\hline 5 & 23807 & 15294 & 9899 & 10671 & 10646 & 10545 & 10520 & 13553 & 12617 & 11013 & 10646 & 12791 & 9637 & 4498 \\
\hline 6 & 23672 & 15125 & 10102 & 10626 & 10587 & 10655 & 10527 & 13370 & 12586 & 11113 & 10846 & 12752 & 9737 & 4497 \\
\hline 7 & 20056 & 13026 & 8549 & 9216 & 9211 & 9043 & 9167 & 11405 & 10746 & 9385 & 9145 & 10765 & 8285 & 3920 \\
\hline 8 & 20285 & 13231 & 8692 & 9277 & 9238 & 9162 & 9140 & 11660 & 10832 & 9598 & 9292 & 11117 & 8433 & 4075 \\
\hline 9 & 17177 & 11012 & 7418 & 7981 & 7982 & 7852 & 7911 & 9930 & 9249 & 8233 & 7984 & 9405 & 7140 & 3422 \\
\hline 10 & 20478 & 13176 & 8772 & 9251 & 9196 & 9229 & 9226 & 11590 & 10976 & 9558 & 9353 & 10917 & 8420 & 3900 \\
\hline 11 & 19040 & 12162 & 7894 & 8385 & 8350 & 8293 & 8272 & 10699 & 9977 & 8672 & 8464 & 10079 & 7696 & 3560 \\
\hline 12 & 17569 & 11426 & 7619 & 8041 & 8064 & 8038 & 7997 & 10119 & 9545 & 8275 & 8078 & 9571 & 7349 & 3398 \\
\hline 13 & 13985 & 9092 & 5937 & 6217 & 6180 & 6237 & 6218 & 7935 & 7432 & 6594 & 6355 & 7620 & 5766 & 2610 \\
\hline 14 & 11700 & 7676 & 5097 & 5295 & 5291 & 5333 & 5270 & 6812 & 6381 & 5586 & 5419 & 6398 & 4877 & 2299 \\
\hline 15 & 11118 & 7415 & 4883 & 5277 & 5229 & 5150 & 5158 & 6591 & 6044 & 5399 & 5240 & 6209 & 4767 & 2236 \\
\hline 16 & 11704 & 7935 & 5287 & 5677 & 5627 & 5518 & 5589 & 7105 & 6568 & 5858 & 5652 & 6816 & 5060 & 2534 \\
\hline 17 & 9015 & 5952 & 3930 & 4227 & 4212 & 4168 & 4139 & 5356 & 4909 & 4437 & 4193 & 5116 & 3833 & 1854 \\
\hline 18 & 11043 & 7201 & 4760 & 5088 & 5069 & 5071 & 5055 & 6336 & 5960 & 5313 & 5098 & 6000 & 4631 & 2148 \\
\hline 19 & 5475 & 3706 & 2557 & 2685 & 2699 & 2694 & 2689 & 3307 & 3185 & 2767 & 2747 & 3152 & 2504 & 1272 \\
\hline 20 & 9930 & 6489 & 4245 & 4452 & 4462 & 4444 & 4375 & 5694 & 5320 & 4627 & 4550 & 5361 & 4137 & 1920 \\
\hline 21 & 5354 & 3527 & 2297 & 2509 & 2503 & 2465 & 2466 & 3192 & 2968 & 2657 & 2481 & 3041 & 2274 & 1044 \\
\hline 22 & 4869 & 3265 & 2172 & 2310 & 2315 & 2323 & 2265 & 2985 & 2699 & 2468 & 2341 & 2846 & 2146 & 995 \\
\hline Totais & 365116 & 236364 & 156077 & 166333 & 165641 & 164674 & 164476 & 209338 & 195453 & 172302 & 167020 & 198456 & 151066 & 71144 \\
\hline
\end{tabular}




\subsection{Parte I - Estimação e Estudo das Janelas de Influência}

Para facilitar a análise dos dados optou-se por, primeiramente, identificar alguns subgrupos das populações segundo sua ancestralidade primária, de acordo com a origem geográfica dos ancestrais, conforme documentação do projeto HapMap e indicado na Tabela 4.1. A Tabela 4.3 mostra como o conjunto de dados foi subdividido.

Tabela 4.3: Agrupamento das populações segundo sua ancestralidade primária

\begin{tabular}{c|l|c} 
Ancestralidade & Populações & Cor Adotada \\
\hline Africana & ASW, LWK, YRI, MKK & roxa \\
Ameríndea & MEX, GIH & vermelha \\
Asiática & CHB, CHD, JPT & amarela \\
Européia & TSI, CEU & azul \\
Brasileira & BRZ & verde \\
\hline
\end{tabular}

\subsubsection{Tamanhos das Janelas de Cada População}

Inicialmente, considerando então os dados genômicos (SNPs) codificados de cada população, foram estimadas as janelas de influência (Jp) por meio da aplicação da metodologia descrita na Seção 2.2.1. O processamento foi efetuado por população e em cada cromossomo, individualmente, de forma sequencial. Adicionalmente, todos os indivíduos (1.124 amostras) foram processados sem distinção de população originária; a esse conjunto deu-se o nome de 'TOT', alusivamente a todas as populações. As análises foram realizadas em um computador pessoal com processador Intel Core $i 7^{\circledR}$, com 8 Gb de memória, levando cerca de 40 horas para sua execução. Conforme citado na Seção 2.2.1 do Capítulo 2, o limite máximo de tamanho da vizinhança à esquerda e à direita de 20 posições, adotado na implementação do algoritmo, não teve influência nos resultados, uma vez que nenhuma vizinhança estimada foi superior a 4 SNPs.

A Tabela 4.2 apresenta o número de janelas encontradas por cromossomo em cada população, além do número total de janelas por população. Nota-se claramente que as populações de origem africana têm, em geral, um número maior de janelas, número esse que vai diminuindo gradualmente até a população brasileira, com o menor número de janelas.

Quando analisamos o tamanho médio dessas janelas, definido, para cada população, como a média aritmética do número de SNPs presentes nas janelas encontradas, as populações africanas são também aquelas que possuem as menores médias, enquanto que a população brasileira apresenta o maior tamanho médio entre todas as populações estudadas (ver Figuras 4.2 e 4.3).

É sabido que o genoma das populações de origem africana tem blocos haplotípicos menores quando comparados com outras populações (Schlesinger, 2010). Neste estudo, as janelas das populações africanas, mais antigas na história da humanidade, são mais numerosas contudo menores, de acordo, portanto, com o que é esperado, uma vez que, devido ao maior número de cruzamentos, há uma redução progressiva no tamanho dos blocos do genoma que são transmitidos aos descendentes, consequência das recombinações gênicas ocorridas. A população brasileira, ao contrário, possui 
menos janelas e maiores em média, representativas de blocos maiores do genoma ainda presentes (conservados), evidenciando sua história recente de miscigenação.

A Figura 4.4 mostra a distribuição do tamanho das janelas em cada população. Apesar de visualmente muito parecidas, de modo geral, as populações mais antigas têm uma distribuição mais concentrada em torno de tamanhos menores, enquanto que nas populações mais recentes há um espaçamento maior (notar a mudança de patamar da mediana), acompanhada por pontos atípicos gradualmente mais distantes do corpo central do gráfico.

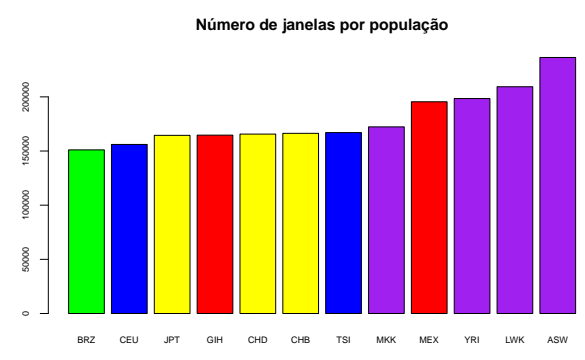

Figura 4.2: Número de janelas por população.

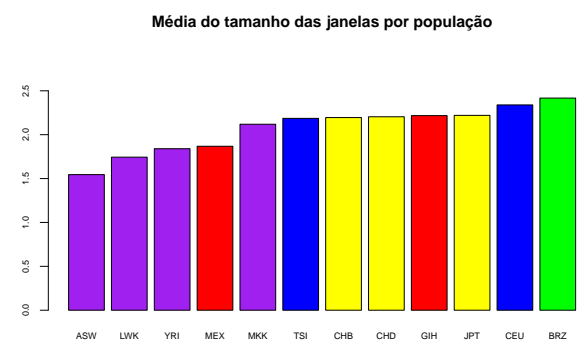

Figura 4.3: Tamanho médio das janelas por população.

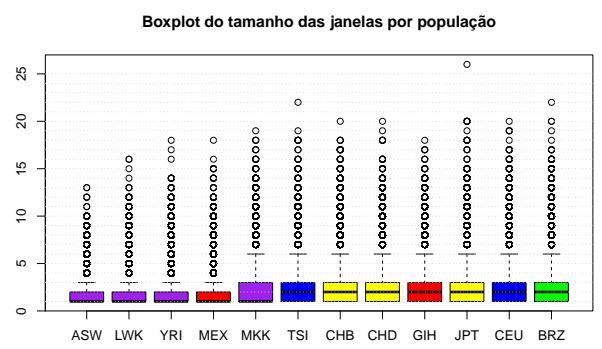

Figura 4.4: Distribuição do tamanho médio das janelas por população.

\subsubsection{Distribuição das Janelas por População}

As populações envolvidas neste estudo acabaram por se diferenciar não apenas no número de janelas, no tamanho médio e na distribuição desse tamanho, mas também no número de janelas com tamanhos considerados 'grandes'. Neste sentido, foi adotado o tamanho 12 como ponto de corte 
entre janelas 'grandes' e janelas 'pequenas' e analisada a distribuição dessas janelas ao longo do genoma, em cada população. Nota-se também que o número dessas janelas (maiores ou iguais a 12 SNPs) é superior nas populações mais recentes, como a brasileira.


Figura 4.5: Comparação da distribuição das janelas maiores nas populações $A S W$ e BRZ.

A Figura 4.5 ilustra bem essa afirmação, comparando a ocorrência de janelas 'grandes' nas populações ASW e BRZ, respectivamente, as populações com menor e maior tamanho médio de janelas. Nesta figura, todas as janelas encontradas são representadas por linhas verticais sendo, na cor cinza as janelas 'pequenas' e na cor preta, em destaque, as janelas 'grandes'. As linhas vermelhas verticais representam os limites de cada cromossomo. Reflete-se bem, dessa forma, a diferença no tamanho dos blocos do genoma como consequência, muito provavelmente, do número de cruzamentos aos quais cada população foi exposta ao longo dos tempos.

Esse mesmo comportamento foi observado para as demais populações, ou seja, as mais antigas possuem poucas ocorrências de janelas 'grandes' e, à medida que caminhamos para populações mais recentes, o número dessas janelas aumenta. No Apêndice A.3, a Figura A.1 mostra a comparação das distribuições para todas as populações.

\subsubsection{Comparação de Resultados Extremos}

A diferença encontrada nas características descritivas das janelas de cada população não é resultado de uma região específica do genoma ou de janelas isoladas, ao contrário, é um comportamento encontrado ao longo de todos os cromossomos, de forma quase uniforme. No caso das populações ASW e BRZ, as quais se encontram em posições opostas nos critérios até agora discutidos, a Figura 4.6 mostra a distribuição do tamanho das janelas em cada cromossomo.

Ressalta-se primeiramente nesta figura a diferença de escala, evidenciando a diferença dos tamanhos das janelas entre as duas populações. Adicionalmente, a mediana, medida de posição central robusta para dados extremos, é consistentemente maior na população brasileira. O valor máximo dos boxplots da população ASW em cada cromossomo equivale ao terceiro quartil na população 

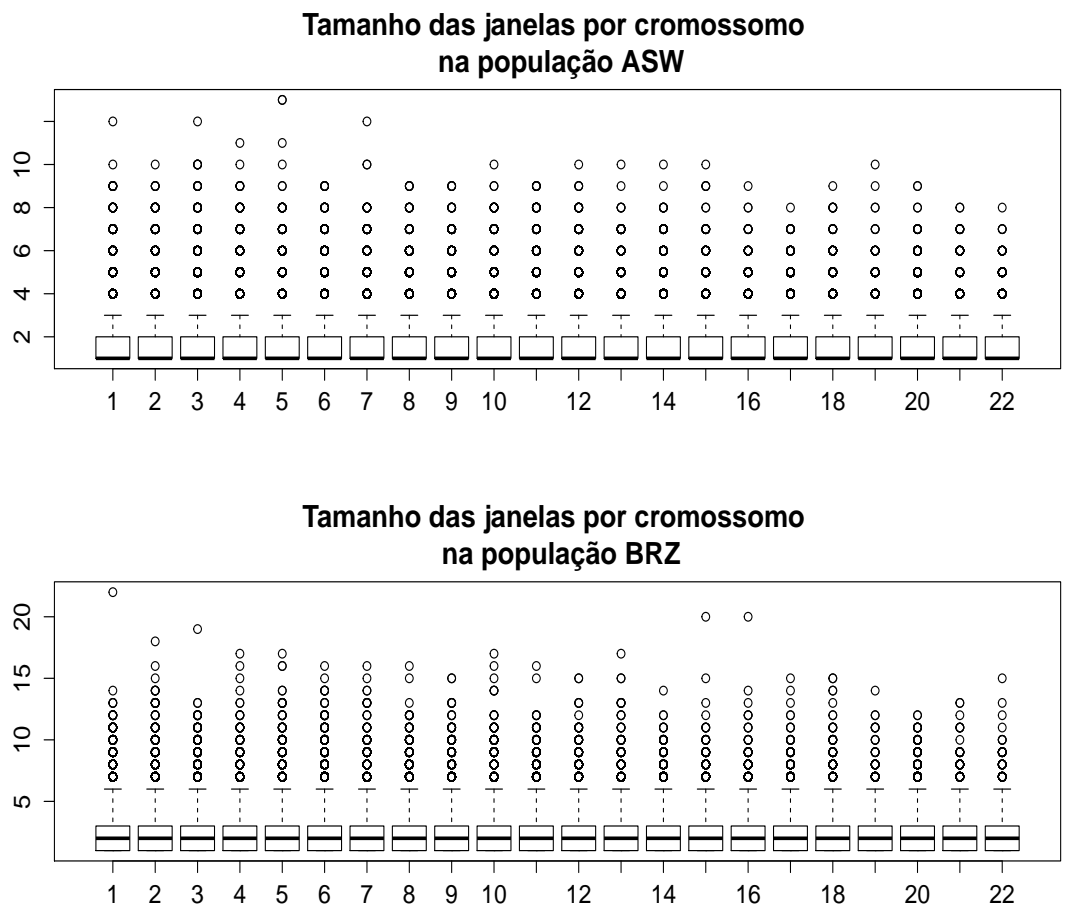

Figura 4.6: Distribuição das janelas por cromossomo nas populações $A S W$ e BRZ.

BRZ. Finalmente, poucas são as ocorrências, por exemplo, de janelas com mais de 10 SNPs na população ASW enquanto que na população brasileira esse número é bastante superior e ocorre em todos os cromossomos (de fato, as populações ASW e BRZ contêm, respectivamente, 7 e 383 janelas com tamanho superior a 10 SNPs).

\subsection{Parte II - Estimação e Estudo das Janelas de Consenso}

De posse das janelas de influência de cada população do estudo, dadas suas respectivas posições em termos do número relativo do SNP e do número do cromossomo, foi desenvolvido um algoritmo utilizando a linguagem de programação $\mathrm{R}$ para encontrar as janelas de consenso maximais (denominada $J c$ ), conforme discutido e proposto no Capítulo 2. O código fonte está disponível no Apêndice A.1.2.

Para ilustrar o procedimento, a Figura 4.7 mostra o resultado obtido para os primeiros SNPs do cromossomo 1. As primeiras duas janelas têm comprimento unitário, pois, em todas as populações os dois primeiros SNPs são independentes da sua vizinhança. Os 4 SNPs seguintes compõem a terceira janela de consenso, enquanto que os dois próximos SNPs formam a quarta janela e assim por diante. A imagem deixa claro que a janela de consenso maximal é, portanto, determinada a partir da 'sombra' das janelas de influência encontradas em cada população.

A última linha da Figura 4.7, mostra as janelas de influência obtidas quando todos os indivíduos da amostra são processados juntos (denominada $J t$ ), sem a estratificação populacional e comprova, empiricamente, o fato exposto no Capítulo 2 de que as janelas assim formadas não correspondem ao 
conceito de janela de consenso proposto. Em outras palavras, as amostras populacionais tomadas separadamente não constituem subamostras de uma única população (formada pelas 12 populações que supostamente teriam a mesma distribuição genotípica nos vários locos) mas, ao contrário, são originadas por trinomiais distintas (ao longo dos locos de SNPs). 


\section{Primeiras 15 janelas de consenso no cromossomo 1}

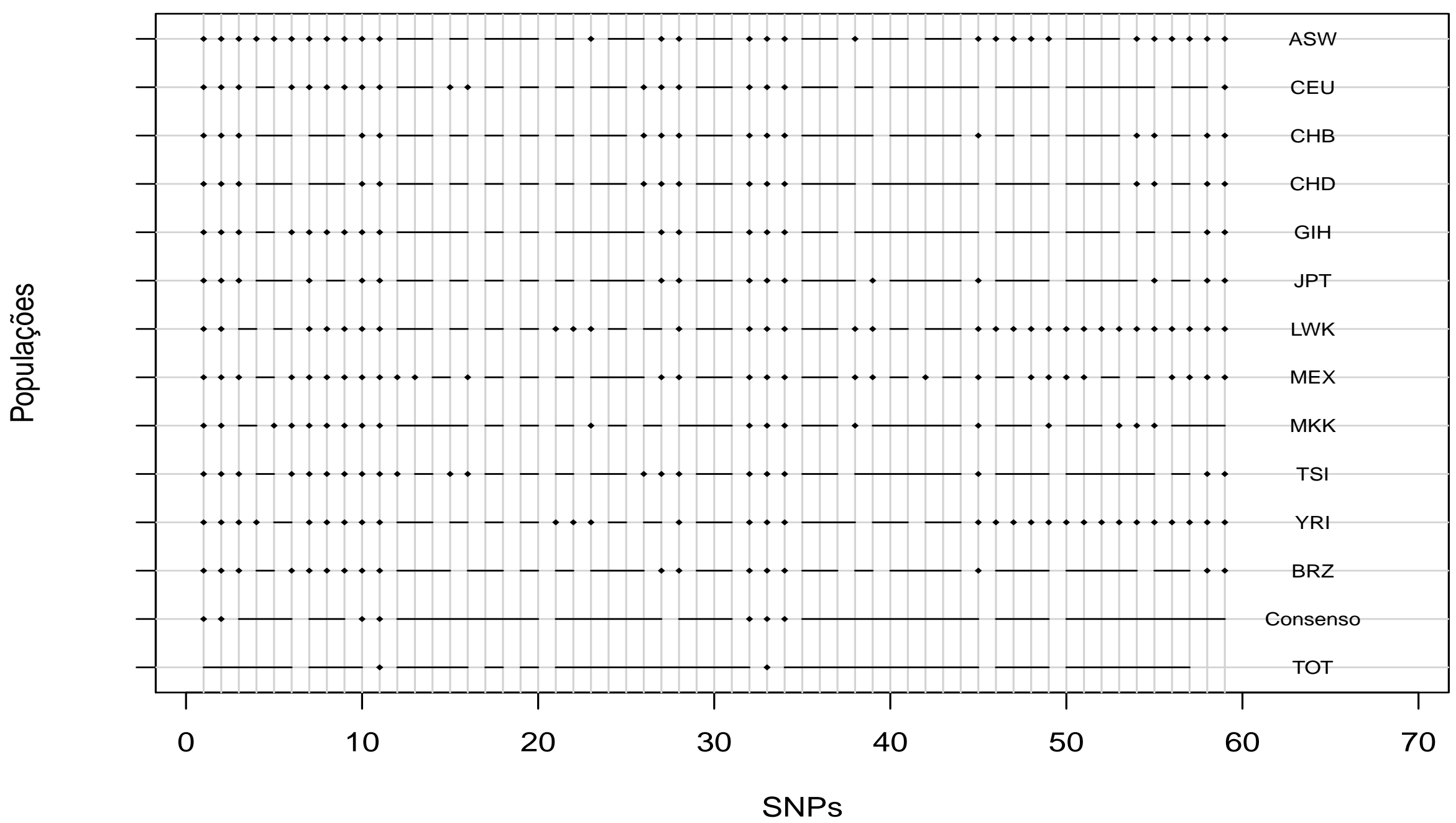




\subsubsection{Caracterização das Janelas de Consenso Maximal}

Os índices de heterogeneidade (IH) e de similaridade (IS), conforme definição proposta no Capítulo 3 , foram calculados para todas as janelas de consenso.
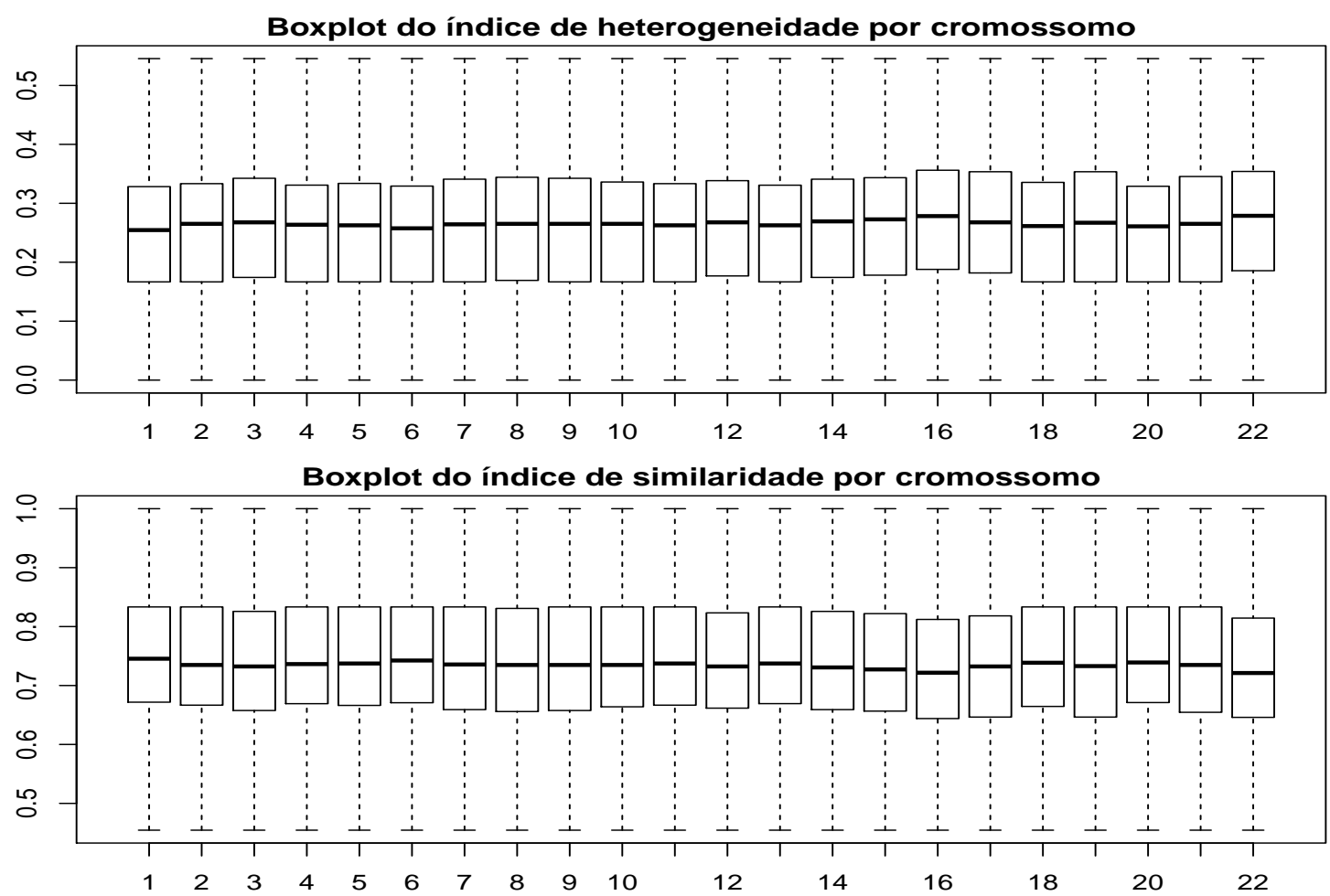

Figura 4.8: Boxplot dos indices IS e IH por cromossomo.

A Figura 4.8 mostra que o índice de heterogeneidade (IH), bem como seu complemento (IS), tem uma distribuição bastante parecida ao longo dos cromossomos, com os 5 pontos do gráfico boxplot com valores muito próximos. Esse comportamento deixa claro que não há, segundo esse critério, nenhum cromossomo ou região específica do genoma que possa ser destacada como mais homogênea ou mais heterogênea. Na verdade, a avaliação dessa figura nos leva a acreditar que a distribuição de regiões de dependência, com mais ou menos diversidade não está associada a porções específicas do genoma mas, ao contrário, encontra-se espalhada por todos os cromossomos.

Independentemente do cromossomo, os valores do índice de heterogeneidade (IH) são inferiores a 0,55 , indicando que, no máximo, são encontradas regiões do genoma com heterogeneidade de grau moderado entre as 12 populações estudadas. No que diz respeito ao valor do IH em função do tamanho da janela de consenso, notamos na Figura 4.9 que há uma leve tendência de aumento da heterogeneidade conforme o tamanho da janela de consenso aumenta, o que, de certa forma, parece intuitivamente coerente, uma vez que, com o aumento da região em termos do número de SNPs adjacentes, é razoável esperar que as janelas de influência de cada população acabem por ser mais diferentes entre si. 


\section{Dispersão da similaridade $\mathbf{X}$ tamanho das janelas de consenso}



Dispersão da heterogeneidade $\mathbf{X}$ tamanho das janelas de consenso

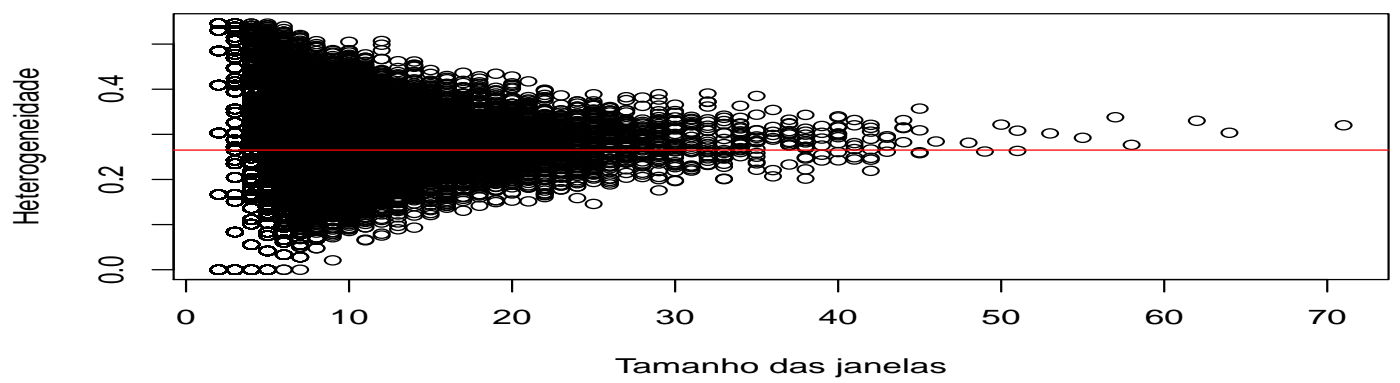

Figura 4.9: Dispersão dos indices IS e IH (a linha vermelha representa a mediana do indice respectivo)

\subsubsection{Região HLA do Genoma - Janelas Homogêneas}

A região HLA (Human Leukocyte Antigen) é uma porção relativamente pequena do genoma humano, situada no cromossomo 6 e responsável pela resposta imunológica humana (ver Figura 4.10). De fato, é uma região alvo de muitos estudos e, por conta disso, subdividida em várias regiões menores, como mostra a Figura 4.11. Sua análise é importante especialmente no caso de transplantes, em que a compatibilidade entre doador e receptor é medida para avaliar a possibilidade de rejeição.

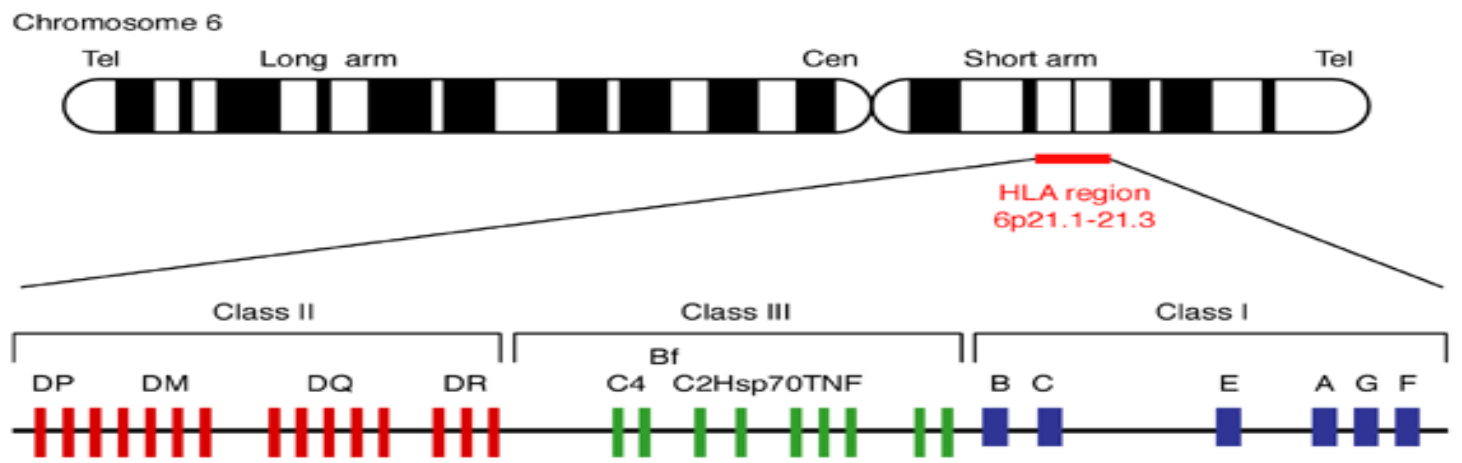

Figura 4.10: Cromossomo 6 com a região HLA em destaque.

Estima-se que, em grande parte, a presença do ser humano na Terra e sua sobrevivência em face à exposição a inúmeros agentes externos, esteja relacionada ao mecanismo que a evolução natural impôs a esta região genômica. Assim sendo, dentro da proposta deste estudo, deve ser uma região com grandes regiões de dependência e espera-se, comparativamente às demais regiões, índices de similaridade de grau alto em suas janelas de consenso, dado que a conservação dessa região é vital 

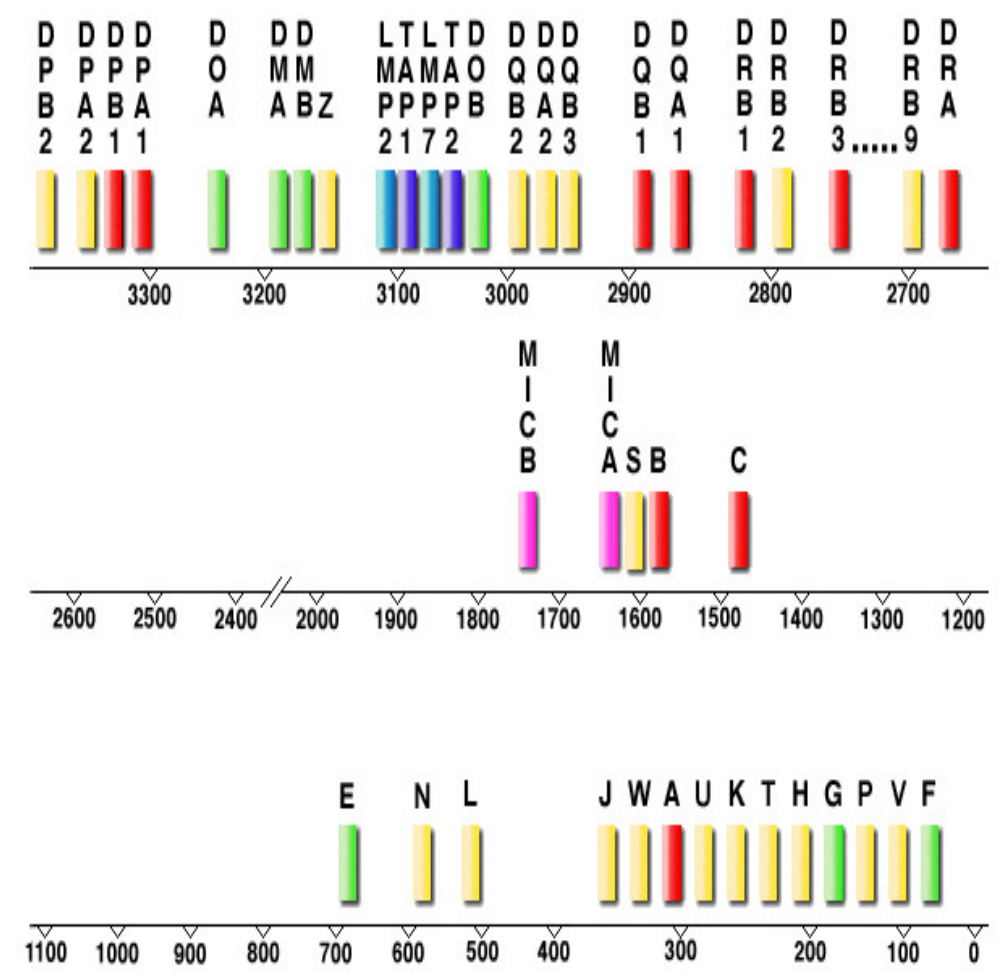

Figura 4.11: Mapa das regiões HLA no cromossomo 6. Fonte: site: http://hla.alleles.org (Robinson et al., 2015)

ao longo das gerações.

Foi utilizado um conjunto com 443 SNPs localizados na região HLA (Beck et al., 2014), dos quais, apenas 49 foram encontrados nos SNPs selecionados neste estudo. A Tabela 4.4 contém um resumo dos SNPs comuns e sua localização dentro da região HLA.

Tabela 4.4: Tabela resumo das regiões HLA encontradas

\begin{tabular}{llll}
\hline Região & Qtd SNPs & SNP inicial & SNP final \\
\hline HLA-F-AS1 & 2 & 5215 & 5219 \\
HLA-G & 1 & 5250 & 5250 \\
HLA-DRA & 8 & 5759 & 5766 \\
HLA-DQA1 & 1 & 5782 & 5782 \\
HLA-DQA2 & 7 & 5810 & 5816 \\
HLA-DQB2 & 3 & 5819 & 5821 \\
HLA-DOB & 5 & 5836 & 5840 \\
HLA-DMB & 3 & 5875 & 5877 \\
HLA-DOA & 6 & 5892 & 5897 \\
HLA-DPA1 & 3 & 5917 & 5921 \\
HLA-DPB1 & 10 & 5919 & 5929 \\
\hline & 49 & \\
\hline
\end{tabular}

Os SNPs comuns, apesar de próximos, não são contíguos dentro da amostra. A alternativa então para verificar o perfil das janelas de consenso na região HLA é utilizar cada SNP como um indicador de posição e avaliar as características das janelas de consenso no seu entorno. Assim, para cada 
SNP foi verificada a existência ou não de uma janela de consenso em sua posição específica. Dos 49 SNPs comuns, 45 (92\%) deles estavam numa localização na qual existia uma janela de consenso de tamanho igual a 2 ou superior e, consequentemente, apenas 4 correspondiam a SNPs independentes. Na Figura 4.12, a título de exemplo, são mostradas as janelas encontradas nas posições dos SNPs encontrados na região DOB do HLA. Uma ilustração de todos os 49 SNPs, separados por sub-regiões do HLA está colocada no Apêndice (ver Figura A.2 em Apêndice A.3).



Figura 4.12: SNPs comuns na região HLA-DOB e as janelas de influência e de consenso do entorno.

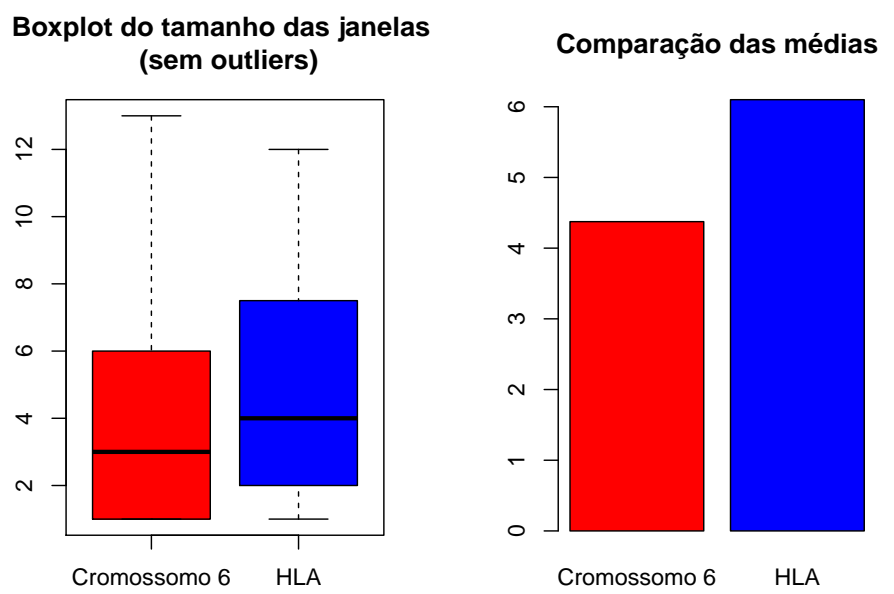

Figura 4.13: Comparação dos tamanhos das janelas de consenso na região HLA e no cromossomo 6.

Foram encontradas 20 janelas de consenso nas regiões indicadas pelos SNPs existentes na HLA, sendo 16 delas com tamanho não unitário. Considerando todas as janelas de consenso no cromos- 
Tabela 4.5: Janelas de consenso existentes nas regiões HLA encontradas

\begin{tabular}{lccccc}
\hline Região & SNP inicial & SNP final & Tamanho & Similaridade & Heterogeneidade \\
\hline HLA-F-AS1 & 5215 & 5217 & 3 & $79.55 \%$ & $20.45 \%$ \\
HLA-F-AS1 & 5218 & 5224 & 7 & $61.62 \%$ & $38.38 \%$ \\
HLA-G & 5250 & 5250 & 1 & $100 \%$ & $0 \%$ \\
HLA-DRA & 5750 & 5771 & 22 & $79.87 \%$ & $20.13 \%$ \\
HLA-DQA1 & 5779 & 5785 & 7 & $76.26 \%$ & $23.74 \%$ \\
HLA-DQA2 & 5809 & 5814 & 6 & $77.27 \%$ & $22.73 \%$ \\
HLA-DQA2 & 5815 & 5815 & 1 & $100 \%$ & $0 \%$ \\
HLA-DQA2 & 5816 & 5816 & 1 & $100 \%$ & $0 \%$ \\
HLA-DQB2 & 5818 & 5823 & 6 & $93.94 \%$ & $6.06 \%$ \\
HLA-DOB & 5836 & 5837 & 2 & $51.52 \%$ & $48.48 \%$ \\
HLA-DOB & 5838 & 5842 & 5 & $74.62 \%$ & $25.38 \%$ \\
HLA-DMB & 5875 & 5876 & 2 & $83.33 \%$ & $16.67 \%$ \\
HLA-DMB & 5877 & 5877 & 1 & $100 \%$ & $0 \%$ \\
HLA-DOA & 5892 & 5893 & 2 & $100 \%$ & $0 \%$ \\
HLA-DOA & 5894 & 5895 & 2 & $100 \%$ & $0 \%$ \\
HLA-DOA & 5896 & 5907 & 12 & $65.15 \%$ & $34.85 \%$ \\
HLA-DPA1 & 5910 & 5925 & 16 & $76.36 \%$ & $23.64 \%$ \\
HLA-DPB1 & 5910 & 5925 & 16 & $76.36 \%$ & $23.64 \%$ \\
HLA-DPB1 & 5926 & 5927 & 2 & $100 \%$ & $0 \%$ \\
HLA-DPB1 & 5928 & 5935 & 8 & $77.49 \%$ & $22.51 \%$ \\
\hline
\end{tabular}

somo 6, o tamanho médio é de 4,38 SNPs. Nas janelas de consenso da região HLA o tamanho médio é de 6,1 SNPs, o que corrobora com a hipótese de que, sendo esta região conservada no genoma, suas regiões de dependência, indicadas aqui pelo tamanho absoluto das janelas de consenso, são comparativamente maiores em relação a outras regiões do mesmo cromossomo (ver Figura 4.13).

Evidenciada a questão do efeito da conservação no tamanho das janelas de consenso, fica ainda a necessidade de analisar o perfil dessas janelas no que diz respeito à sua similaridade. No cromossomo 6, a mediana do índice de similaridade (IS) das janelas de consenso está em 0,74 , indicando um elevado grau de similaridade. Dos 49 SNPs comuns, 40 deles (82\%) estão em posições nas quais existem janelas com similaridade maior que a mediana, sendo que 11 (22\%) pertencem a janelas com similaridade maior inclusive que o terceiro quartil ( $\mathrm{IS}=0,83$ ). A Tabela 4.5 contém uma relação de todas as janelas de consenso encontradas, com suas características em termos de tamanho e similaridade, organizada pelas sub-regiões HLA.

Assim, utilizando os SNPs comuns como indicadores das posições da região HLA dentro do genoma, encontramos nesses entornos, janelas de consenso com tamanho médio maior do que a média geral do cromossomo e com índices de similaridade superiores à mediana do mesmo cromossomo, indicando que a conservação dessa região acabou se refletindo na maior dependência entre seus SNPs, dependência essa que é, em geral, comum para todas as 12 populações sob estudo, dado o elevado índice de similaridade de suas janelas de consenso. 
Tabela 4.6: Distribuição das janelas heterogêneas com $I H>50 \%$ ao longo dos cromossomos

\begin{tabular}{l|ccccccccccc}
\hline Cromossomo & 1 & 2 & 3 & 4 & 5 & 6 & 7 & 8 & 9 & 10 & 11 \\
\hline Janelas & 120 & 129 & 118 & 105 & 88 & 88 & 92 & 87 & 106 & 83 & 69 \\
\hline \hline Cromossomo & 12 & 13 & 14 & 15 & 16 & 17 & 18 & 19 & 20 & 21 & 22 \\
\hline Janelas & 63 & 74 & 58 & 50 & 79 & 55 & 47 & 42 & 41 & 20 & 21 \\
\hline
\end{tabular}

\subsubsection{Classificador - Janelas Heterogêneas}

Quanto mais heterogênea uma determinada janela de consenso, mais discriminante ela deve ser para as populações. Adotou-se como ponto de corte para seleção das janelas o índice de heterogeneidade igual ou maior a 0,50 (considere que, independentemente do cromossomo, o terceiro quartil do IH foi igual a 0,34 ), obtendo assim 1.646 janelas, distribuídas ao longo dos cromossomos de acordo com a Tabela 4.6. Para cada janela foi construída uma tabela com todos os diferentes genótipos e sua respectiva contagem por população. A Tabela 4.7 ilustra o procedimento para a janela 48 presente no cromossomo 13. Esta janela foi escolhida por apresentar apenas 3 genótipos diferentes, o que permitirá a visualização do funcionamento do classificador em um mapa bidimensional mais à frente.

Tabela 4.7: Exemplo da tabela de contingência do classificador

\begin{tabular}{rrrr}
\hline & 022 & 121 & 220 \\
\hline ASW & 41 & 6 & 0 \\
BRZ & 111 & 23 & 1 \\
CEU & 78 & 32 & 2 \\
CHB & 76 & 8 & 0 \\
CHD & 73 & 12 & 0 \\
GIH & 84 & 3 & 0 \\
JPT & 72 & 12 & 0 \\
LWK & 76 & 12 & 1 \\
MEX & 40 & 9 & 0 \\
MKK & 107 & 27 & 1 \\
TSI & 72 & 15 & 1 \\
YRI & 98 & 15 & 0 \\
\hline
\end{tabular}

Utilizando a técnica de Análise de Correspondência proposta no Capítulo 3, é possível representar o conjunto de valores das duas variáveis de entrada da tabela, simultaneamente, a partir de um mapa com $(n-1)$ dimensões, onde $n$ é a menor das duas dimensões das variáveis. Conforme exposto no Capítulo 3, dado que o objetivo é determinar a população mais próxima de um determinado genótipo, uma das possibilidades, que foi adotada neste trabalho, é a confecção de um mapa Biplot, no qual os diferentes genótipos (colunas na tabela de contingência) são representados nos vértices e definem, cada qual, uma direção e as populações (linhas na tabela de contingência) são representadas de tal forma que o produto escalar entre os vetores linha e coluna reconstrua a tabela de contingência (Greenacre, 2007). Assim, tendo como base a Tabela 4.7, como o número de diferentes genótipos é igual a 3, é possível representar os dados da tabela em um mapa bidimensional sem perda de informação, o que é mostrado na Figura 4.14. A análise dessa figura nos faz concluir que o genótipo '121' e o genótipo '220' estão mais associados com a população 'CEU', enquanto que o genótipo '022' associa-se com a população 'GIH'. 




Figura 4.14: Exemplo do Biplot bidimensional produzido pela ACS da Tabela 4.7.

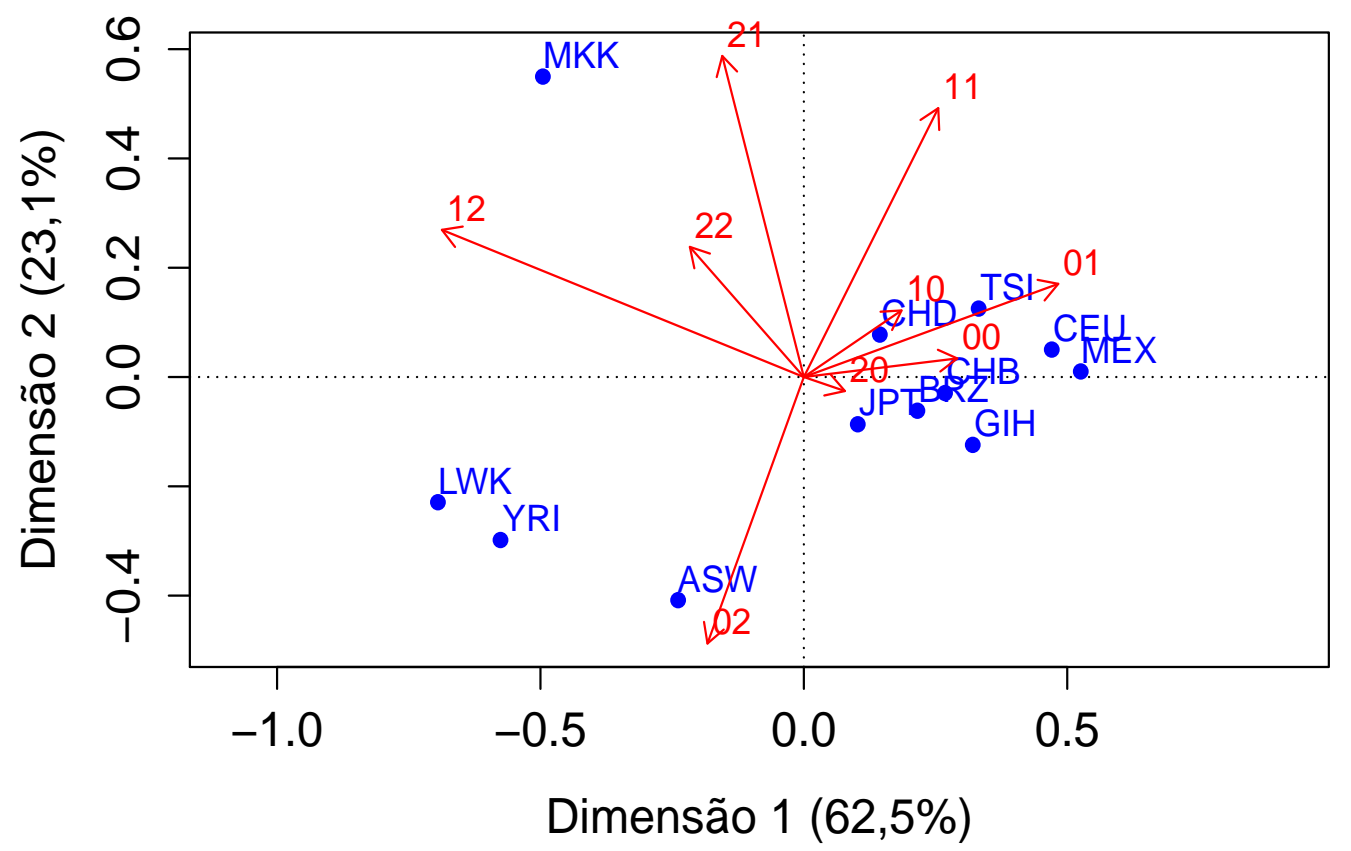

Figura 4.15: Exemplo do Biplot bidimensional produzido para uma janela com mais de três genótipos.

Apenas para ilustração, a Figura 4.15 seria o Biplot bidimensional produzido para uma janela com 9 genótipos diferentes e, portanto, em duas dimensões, consegue-se representar 85,6\% da inércia total. 
O código fonte em $\mathbf{R}$ utilizado para o classificador está disponível no Apêndice A.1.3.

Foi retirada uma amostra aleatória de tamanho 100 do conjunto total de 1.124 indivíduos. Para cada uma das 1.646 janelas heterogêneas selecionadas, foi atribuída uma população originária à cada indivíduo, de acordo com o classificador proposto, isto é, de acordo com a menor distância entre essa população e o genótipo do indivíduo naquela janela específica. Finalmente, depois de todas as janelas analisadas, o indivíduo é classificado na população escolhida no maior número de janelas.

\begin{tabular}{r|rrrrrrrrrrrr}
\hline & ASW & CEU & CHB & CHD & GIH & JPT & LWK & MEX & MKK & TSI & YRI & BRZ \\
\hline 515 LWK & 162 & 103 & 80 & 68 & 114 & 98 & 228 & 107 & 239 & 74 & 196 & 172 \\
731 MKK & 144 & 112 & 90 & 75 & 137 & 82 & 143 & 109 & 323 & 94 & 156 & 175 \\
$800 \mathrm{TSI}$ & 73 & 249 & 113 & 104 & 178 & 109 & 56 & 145 & 103 & 243 & 72 & 197 \\
$163 \mathrm{CHB}$ & 62 & 111 & 236 & 237 & 162 & 232 & 68 & 148 & 79 & 111 & 74 & 114 \\
$232 \mathrm{CHB}$ & 65 & 129 & 257 & 217 & 163 & 218 & 58 & 155 & 83 & 91 & 87 & 110 \\
$1089 \mathrm{BRZ}$ & 88 & 206 & 92 & 104 & 149 & 101 & 88 & 170 & 148 & 136 & 96 & 257 \\
$521 \mathrm{LWK}$ & 164 & 94 & 75 & 71 & 103 & 89 & 264 & 93 & 240 & 73 & 200 & 164 \\
$1027 \mathrm{BRZ}$ & 67 & 224 & 85 & 109 & 169 & 110 & 61 & 165 & 89 & 216 & 78 & 269 \\
$726 \mathrm{MKK}$ & 147 & 106 & 73 & 83 & 114 & 89 & 149 & 120 & 342 & 88 & 164 & 163 \\
$654 \mathrm{MKK}$ & 142 & 103 & 90 & 90 & 117 & 106 & 149 & 110 & 294 & 87 & 171 & 183 \\
$991 \mathrm{BRZ}$ & 87 & 209 & 80 & 101 & 145 & 118 & 73 & 158 & 119 & 173 & 93 & 271 \\
$518 \mathrm{LWK}$ & 153 & 92 & 84 & 78 & 108 & 77 & 232 & 89 & 257 & 82 & 199 & 181 \\
$1099 \mathrm{BRZ}$ & 95 & 169 & 94 & 93 & 150 & 110 & 82 & 148 & 116 & 169 & 115 & 295 \\
. &. &. &. &. &. &. &. &. &. &. &. &. \\
. &. &. &. &. &. &. &. &. &. &. &. &. \\
\hline SOMA & 11054 & 15723 & 12058 & 12491 & 15188 & 13790 & 10566 & 13608 & 15703 & 13081 & 12278 & 18088 \\
\hline
\end{tabular}

Figura 4.16: Classificação utilizando mapa Biplot

Tabela 4.8: Tabela de validação do classificador

\begin{tabular}{rrrrrrrrrrrrr}
\hline & ASW & BRZ & CEU & CHB & CHD & GIH & JPT & LWK & MEX & MKK & TSI & YRI \\
\hline ASW & 6 & 0 & 0 & 0 & 0 & 0 & 0 & 0 & 0 & 0 & 0 & 0 \\
BRZ & 0 & 14 & 0 & 0 & 0 & 0 & 0 & 0 & 0 & 0 & 0 & 0 \\
CEU & 0 & 0 & 8 & 0 & 0 & 0 & 0 & 0 & 0 & 0 & 0 & 0 \\
CHB & 0 & 0 & 0 & 8 & 1 & 0 & 0 & 0 & 0 & 0 & 0 & 0 \\
CHD & 0 & 0 & 0 & 0 & 3 & 0 & 0 & 0 & 0 & 0 & 0 & 0 \\
GIH & 0 & 0 & 0 & 0 & 0 & 6 & 0 & 0 & 0 & 0 & 0 & 0 \\
JPT & 0 & 0 & 0 & 0 & 0 & 0 & 6 & 0 & 0 & 0 & 0 & 0 \\
LWK & 0 & 0 & 0 & 0 & 0 & 0 & 0 & 2 & 0 & 7 & 0 & 0 \\
MEX & 0 & 0 & 0 & 0 & 0 & 0 & 0 & 0 & 5 & 0 & 0 & 0 \\
MKK & 0 & 0 & 0 & 0 & 0 & 0 & 0 & 0 & 0 & 9 & 0 & 0 \\
TSI & 0 & 0 & 2 & 0 & 0 & 0 & 0 & 0 & 0 & 0 & 6 & 0 \\
YRI & 0 & 0 & 0 & 0 & 0 & 0 & 0 & 0 & 0 & 1 & 0 & 16 \\
\hline
\end{tabular}

A Figura 4.16 mostra o resultado do classificador para os 15 primeiros indivíduos da amostra: 
a primeira coluna possui o número sequencial do indivíduo dentro do conjunto de dados do estudo, seguido de sua população de origem; as demais colunas mostram para quantas janelas o indivíduo foi classificado em uma determinada população. A classificação final é, portanto, aquela população que corresponde ao maior número de janelas. Estas células estão em destaque na Figura 4.16 para facilitar o entendimento, tendo o fundo verde quando a classificação final está de acordo com a população de origem e com fundo vermelho caso contrário. A Tabela A.1 no Apêndice A.2 tem o resultado do classificador para esta amostra total considerada.

Finalmente, a Tabela 4.8 é um resumo do resultado do classificador, tendo na vertical a população original e na horizontal as populações classificadas. O valor de cada casela representa o número de indivíduos classificados em cada combinação. Dada sua construção, os valores da diagonal principal indicam as classificações corretas enquanto que aqueles fora dessa diagonal são os erros de classificação. Assim, 89 dos 100 indivíduos foram classificados corretamente pelo classificador proposto.

Importante ressaltar que as janelas heterogêneas utilizadas no classificador foram obtidas usando os 1.124 indivíduos do conjunto de dados, ou seja, inclusive os 100 indivíduos retirados para validação. Este não é o procedimento ideal, contudo, foi o adotado neste trabalho pois, uma validação cruzada necessitaria um reprocessamento para obtenção de novas janelas de influência populacionais $(J p)$ e, consequentemente, novas janelas de consenso $(J c)$, utilizando um conjunto de dados sem os indivíduos retirados para validação, o que representaria grande esforço computacional e tempo de processamento ${ }^{3}$.

Como alternativa, para confirmar a validade do classificador, foram executadas 10 realizações do procedimento, utilizando diferentes amostras de 100 indivíduos e, em todos os casos, o acerto foi sempre superior a $90 \%$ da população originária. Adicionalmente, o mesmo classificador foi utilizado, porém, usando um conjunto de 1.646 janelas consideradas homogêneas (neste caso, adotou-se $\mathrm{IS} \geqslant 0,95$ como ponto de corte para janelas homogêneas), obtendo resultados finais sempre abaixo dos índices atingidos quando utilizadas as janelas heterogêneas, evidenciando o alto poder discriminante das últimas. Os resultados detalhados de cada uma das realizações não está mostrado, contudo, a Tabela 4.9 retrata a comparação da taxa de acerto do classificador para cada uma das realizações.

Tabela 4.9: Tabela resumida mostrando os resultados obtidos para o classificador, em diferentes amostras e utilizando diferentes janelas de consenso.

\begin{tabular}{l|cccccccccc} 
Realização & 1 & 2 & 3 & 4 & 5 & 6 & 7 & 8 & 9 & 10 \\
\hline Janelas Heterogêneas & $96 \%$ & $97 \%$ & $96 \%$ & $96 \%$ & $95 \%$ & $96 \%$ & $95 \%$ & $96 \%$ & $91 \%$ & $92 \%$ \\
Janelas Homogêneas & $75 \%$ & $66 \%$ & $72 \%$ & $79 \%$ & $67 \%$ & $82 \%$ & $80 \%$ & $71 \%$ & $64 \%$ & $63 \%$ \\
\hline
\end{tabular}

\footnotetext{
${ }^{3}$ Uma possível solução para este problema é discutida no Capítulo 5.
} 


\section{Capítulo 5}

\section{Considerações Finais}

\subsection{Conclusões e Contribuições}

O estudo da evolução humana ao longo do tempo e suas implicações no que diz respeito à ancestralidade que cada um carrega consigo é de fundamental importância para o entendimento das razões que conduziram à supremacia do homem em relação a outras espécies, bem como para indicar caminhos que possam garantir a continuidade desta supremacia, como o aumento de nossa expectativa de vida, com qualidade. O DNA inscrito em nossas células é um retrato não só do presente, mas guarda também registros de nossa própria evolução. A variabilidade genética em nossa espécie é produzida por vários mecanismos evolucionários, mutações, recombinações e inclusive fluxo gênico, a partir da mistura de populações (Lesk, 2005). Essas variações acabam por produzir novos genótipos a partir da combinação de novos alelos, alterando assim os padrões de desequilíbrio de ligação entre locos e, por fim, modificam os haplótipos que são passados aos descendentes.

Este trabalho teve foco em identificar blocos do genoma a partir de marcadores genéticos conhecidos como SNPs (variações em um único nucleotídeo) amostrados em diversas populações mundiais, incluindo a brasileira, com ancestralidades distintas. Tendo em vista que variabilidade genotípica deve ter percorrido caminhos distintos em cada população de estudo, os blocos conservados do genoma devem ser da mesma forma diferentes. Estes blocos, sob o ponto de vista estatístico são então, regiões de dependência dentro do genoma, transmitidas e modificadas ao longo do tempo.

Com base no trabalho de Leonardi (2006, 2007), a técnica de campos Markovianos de alcance variável foi utilizada por Bianchi (2009) analisando uma amostra de um única população, para obter as denominadas janelas de influência a partir de dados de SNPs. No presente trabalho, para verificar se os blocos assim determinados eram capazes de evidenciar os registros evolucionários de cada população, submeteu-se à esse método um conjunto de dados contendo indivíduos de 12 populações mundiais, com ancestralidade supostamente distinta, incluindo entre elas uma amostra da população brasileira.

Uma das contribuições deste trabalho foi para o problema de estimação das janelas de influência em amostras estratificadas, neste sentido, foram consideradas duas versões de função de verossimilhança, uma para todos os dados amostrais indistintamente e outra para os dados estratificados de cada população. Para este segundo caso, propõe-se a construção de janelas de consenso maximal, re- 
sultante da união das janelas de influência de cada população contidas na mesma porção do genoma.

A formulação da função de verossimilhança nos leva a uma distribuição trinomial para cada variável aleatória representativa do genótipo de um determinado SNP. Assim, caso cada população seja simplesmente uma subamostra daquela contendo todos os indivíduos, ou seja, se tanto a amostra completa como a amostra de cada população do estudo forem obtidas a partir da distribuição de mesmas trinomiais para cada SNP, as janelas de consenso deveriam ser iguais às janelas de influência obtidas da amostra completa, sem supor estratificação. Tal resultado nos levaria a concluir que os blocos de SNPs dependentes assim determinados não revelam nada a respeito da ancestralidade diferencial entre as populações.

Empiricamente, mostrou-se que estas duas versões podem conduzir a diferentes resultados. O que se obteve, na análise dos dados das 12 populações mundiais foram janelas de consenso (denominada $J c$ ) diferentes das janelas de influência da amostra total (denominada $J t$ ), evidenciando que as estruturas de regiões dependentes são diferentes entre as populações. Adicionalmente, uma análise descritiva das janelas de influência para cada população mostrou que na população brasileira o tamanho médio dessas janelas é maior do que nas outras populações, de acordo, portanto, com a história recente de miscigenação desta população. No outro extremo, as janelas de influência obtidas para as populações de origem mais remota, como as africanas, possuem tamanho médio menor.

Não só o tamanho médio, mas também a frequência das janelas de influências maiores, é relativamente diferente entre as populações e indicativa da idade evolucionária de cada uma em termos do número de gerações que as distanciam de um marco ancestral. Assim, o modelo de obtenção de blocos de dependência em amostras estratificadas proposto neste trabalho mostrou-se útil na caracterização da história ancestral de populações que tem sido alvo de vários estudos (Schlesinger, 2010).

Em adição, considerando a diversidade das janelas de influência na obtenção de cada janela de consenso, foi proposto um Índice de Heterogeneidade (IH). A interpretação deste índice pode indicar, para cada região do genoma coberta por uma janela de consenso, se as janelas de influência de cada população ali contidas são mais similares (situação na qual a janela de consenso é chamada de homogênea), ou mais distintas (janela de consenso heterogênea).

Como hipótese de estudo, janelas de consenso homogêneas, resultantes de janelas de influência mais similares entre as populações e, em muitos casos, iguais, seriam reflexo de segmentos de dependência dentro do genoma e com pouca diversidade entre populações e, portanto, sugerindo regiões conservadas, mantidas pelo processo de evolução natural. Essa hipótese foi verificada através do estudo da região HLA (Human Leukocyte Antigen), pequena região do cromossomo 6 responsável por nossa resposta imunológica e que guarda nossa história de combate aos agentes externos. Nesta região foram encontradas grandes janelas de consenso homogêneas e o tamanho médio dessas janelas foi superior ao tamanho médio das janelas de consenso encontradas ao longo de todo o cromossomo 6 .

As janelas de consenso heterogêneas, por outro lado, são regiões com dependência dentro do genoma mas com grande diversidade entre populações. Neste sentido, essas regiões podem revelar as 
diferenças entre as populações no que diz respeito ao registro genético de suas ancestralidades. Um classificador, de indivíduos à sua população de origem, foi proposto utilizando recursos da análise de correspondência em tabelas de contingência, construídas a partir das janelas de consenso mais heterogêneas e os genótipos dos indivíduos nestas janelas encontrados em cada população. Submetendo amostras de tamanho 100 extraídas de forma aleatória do conjunto de dados original, o classificador mostrou acerto da população originária em torno de 90\%. O mesmo classificador, utilizando janelas consideradas não heterogêneas, submetido às mesmas amostras, sempre teve resultado final abaixo dos índices atingidos quando utilizadas as janelas heterogêneas. Assim, para garantir maior poder da análise, sugere-se usar o classificador proposto considerando as regiões mais heterogêneas do genoma.

Os resultados do presente trabalho permitem validar a estrutura de dependência do genoma inferida aos dados das 12 populações mundiais, pela caracterização de suas respectivas janelas. As janelas de consenso construídas refletem padrões de dependência específicos, delimitando regiões genômicas com dependência e pouca ou nenhuma diversidade (janelas homogêneas), ou com dependência e alta diversidade (janelas heterogêneas). Estes padrões identificaram a recente história de miscigenação da população brasileira comparada às demais, confirmaram o estado conservado da região HLA, bem como permitem a construção de um classificador com alta probabilidade de acerto. Além disso, se considerarmos que muitos estudos são conduzidos com objetivo de verificar o efeito de um único SNP em uma determinada doença ou característica fenotípica, mas enfrentam o problema de que o efeito isolado de SNPs é, em geral, muito pequeno e de difícil significância estatística, especialmente em situações de múltiplos testes, a determinação de blocos de SNPs, tal como estimados no presente trabalho, pode lançar luz sobre regiões de estudo dentro do genoma ainda não identificadas.

Uma ressalva se faz necessária na conclusão deste trabalho: ao longo de todo o texto foi, por diversas vezes, utilizado o termo ancestralidade sem o devido rigor. Tendo em vista os resultados obtidos, compatíveis com que era esperado e de acordo com literatura prévia, a proposta de identificar regiões dependentes do genoma discutida neste estudo, parece em grande medida, promissora, contudo, a ancestralidade é um conceito muito complexo para ser caracterizado completamente por esta proposta.

\subsection{Estudos Futuros}

No contexto deste trabalho, uma das possibilidades a ser considerada em estudos futuros é a realização de inferências para o Índice de heterogeneidade $(\mathrm{IH})$, que permitam testar a estrutura de estratificação de populações sob estudo. Nota-se que as estimativas das janelas de consenso maximal ou total são as mesmas na ausência de heterogeneidade entre as populações.

O procedimento inferencial utilizado neste trabalho para determinação das regiões de dependência dentro do genoma, supõe independência entre as unidades amostrais. A extensão do modelo de campos Markovianos de alcance variável para tratar dados genotípicos de indivíduos correlacio- 
nados, que possuem algum grau de parentesco, pode ser considerada também em trabalhos futuros. Neste caso, uma alternativa é a inclusão de um efeito aleatório para modelar a dependência entre unidades amostrais, o que implica em uma mudança importante na função de verossimilhança utilizada até agora. Outra alternativa a ser considerada pode ser a modelagem a partir de campos Markovianos de alcance variável em duas dimensões, uma refletindo a dependência entre os SNPs adjacentes no genoma e outra a dependência entre os SNPs que explicam a relação de dependência entre as unidades amostrais.

Para verificação do classificador, sugere-se a validação cruzada, a qual não foi utilizada por limitação de tempo, uma vez que todo o processamento computacional, desde a estimação das janelas de influência populacionais $(J p)$ passando pela montagem das janelas de consenso $(J c)$ e nova seleção das janelas de consenso mais heterogêneas, deveria ser refeito, tendo como base o conjunto de dados sem a amostra retirada para validação. A primeira etapa, isto é, a estimação das janelas de influência populacionais $(J p)$, é calculada para cada população e para cada cromossomo separadamente e, portanto, podem ser executados paralelamente. Uma alternativa seria, então, reescrever o programa de estimação das janelas populacionais $(J p)$, utilizando recursos de paralelismo computacional. Adicionalmente, os processos de montagem das janelas de consenso $(J c)$ e de cálculo dos índices IH e IS, poderiam ser otimizados e organizados em um único código (atualmente estão em programas separados), integrados ao programa de estimação das janelas de influência populacionais, de tal forma que, dada uma matriz de dados $D$ conforme definida no Capítulo 2, a partir de um único processamento, mais eficiente, fosse possível determinar as janelas que seriam utilizadas no classificador.

Por fim, este trabalho foi feito a partir da codificação do genótipo de cada indivíduo nos SNPs, ou seja, considerando o alfabeto $\{0,1,2\}$ obtido das bases nitrogenadas (nucleotídeos) dos dois alelos homólogos recebidos do pai e da mãe. Uma alternativa futura pode ser a formulação da metodologia para sequências de haplótipos, considerando cada cromossomo separadamente, ou seja, a partir do alfabeto $\{0,1\}$. Como comentado no trabalho, esta abordagem tem a desvantagem de requerer o conhecimento da fase alélica, o que exige passos de estimação adicionais, contudo, permite a comparação direta com resultados de outros trabalhos baseados na mesma premissa.

Apenas a título de exemplo, no trabalho desenvolvido por Greenspan e Geiger (Greenspan e Geiger, 2006) foram também utilizados dados de SNPs do projeto HapMap e através do programa HaploBlock (Zucchelli e Kere, 2003), obtidos blocos haplotípicos. Na Figura 5.1, a parte A mostra um resumo dos resultados desse trabalho, no que diz respeito ao comprimento cromossômico e espaçamento médio entre SNPs, ambos medidos em kilobases. A parte $\mathbf{B}$ mostra uma tabela equivalente, elaborada utilizando os valores obtidos com os dados deste trabalho.

Os comprimentos cromossômicos são bastante parecidos entre os dois trabalhos. Como o número de SNPs deste trabalho é, de modo geral, metade do número de SNPs considerados por Greenspan e Geiger, os valores de contagem e espaçamento médio dos SNPs acabam por guardar relação parecida. Assim, pelo menos numa primeira análise, mesmo que não rigorosa, há certa semelhança entre os dois resultados, contudo, se as janelas de consenso tivessem sido obtidas também a partir 


\begin{tabular}{|c|c|c|c|}
\hline \multirow[b]{2}{*}{ Chromosome } & \multirow[b]{2}{*}{ Length } & \multicolumn{2}{|c|}{ SNPs } \\
\hline & & Count & $\begin{array}{c}\text { Mean } \\
\text { spacing }\end{array}$ \\
\hline 1 & 245,416 & 47,618 & 5.15 \\
\hline 2 & 243,363 & 68,659 & 3.54 \\
\hline 3 & 199,162 & 43,880 & 4.54 \\
\hline 4 & 191,628 & 42,213 & 4.54 \\
\hline 5 & 180,747 & 47,651 & 3.79 \\
\hline 6 & 170,674 & 37,013 & 4.61 \\
\hline 7 & 158,508 & 35,460 & 4.47 \\
\hline 8 & 146,201 & 44,926 & 3.25 \\
\hline 9 & 136,199 & 30,902 & 4.41 \\
\hline 10 & 134,982 & 29,391 & 4.59 \\
\hline 11 & 134,292 & 37,281 & 3.60 \\
\hline 12 & 131,969 & 34,894 & 3.78 \\
\hline 13 & 96,204 & 24,138 & 3.99 \\
\hline 14 & 87,070 & 24,104 & 3.61 \\
\hline 15 & 81,870 & 22,762 & 3.60 \\
\hline 16 & 90,025 & 21,516 & 4.18 \\
\hline 17 & 81,652 & 21,511 & 3.80 \\
\hline 18 & 76,096 & 20,545 & 3.70 \\
\hline 19 & 63,742 & 15,265 & 4.18 \\
\hline 20 & 63,623 & 10,794 & 5.89 \\
\hline 21 & 36,965 & 17,071 & 2.17 \\
\hline 22 & 34,877 & 15,520 & 2.25 \\
\hline Overall & $2,785,266$ & 693,114 & 4.02 \\
\hline
\end{tabular}

A All distances are in kilobases. B

\begin{tabular}{crrr}
\hline \multirow{2}{*}{ Cromossomo } & \multicolumn{3}{c}{ SNPs } \\
\cline { 2 - 4 } & Comprimento & SNPs & Dist.Média \\
\hline & & & \\
2 & 246250 & 30011 & 8.21 \\
3 & 242547 & 30841 & 7.86 \\
4 & 199249 & 25464 & 7.83 \\
5 & 191108 & 22523 & 8.49 \\
6 & 180534 & 23807 & 7.58 \\
7 & 170609 & 23672 & 7.21 \\
8 & 158668 & 20056 & 7.91 \\
9 & 146113 & 20285 & 7.20 \\
10 & 140100 & 17177 & 8.16 \\
11 & 135188 & 20478 & 6.60 \\
12 & 134247 & 19040 & 7.05 \\
13 & 132226 & 17569 & 7.53 \\
14 & 96040 & 13985 & 6.87 \\
15 & 86860 & 11700 & 7.42 \\
16 & 81882 & 11118 & 7.37 \\
17 & 88628 & 11704 & 7.57 \\
18 & 78609 & 9015 & 8.72 \\
19 & 75895 & 11043 & 6.87 \\
20 & 63573 & 5475 & 11.61 \\
21 & 62373 & 9930 & 6.28 \\
22 & 33352 & 5354 & 6.23 \\
& 34686 & 4869 & 7.13 \\
\hline & & & \\
& &
\end{tabular}

B \begin{tabular}{rrrr} 
Totais & 2778737 & 365116 & 7.62 \\
\hline
\end{tabular}

Figura 5.1: A) Resultados obtidos pela montagem de haplótiplos proposta por Greenspam e Geiger (Greenspan e Geiger, 2006); B) Espaçamento médio entre SNPs e comprimento cromossômico (em kilobases) obtidos com os dados deste trabalho.

de sequências haplotípicas, outras comparações poderiam ter sido feitas.

O conjunto de resultados obtidos neste trabalho, mostram que a obtenção de blocos dependentes no genoma através do processo estocástico utilizando campos Markovianos é bastante promissor e merece aprofundamento. 


\section{Apêndice A}

\section{Apêndice}

\section{A.1 Códigos Fonte}

\section{A.1.1 Recodificação dos SNPs}

Código fonte em linguagem perl utilizado para re-codificação dos genótipos dos SNPs:

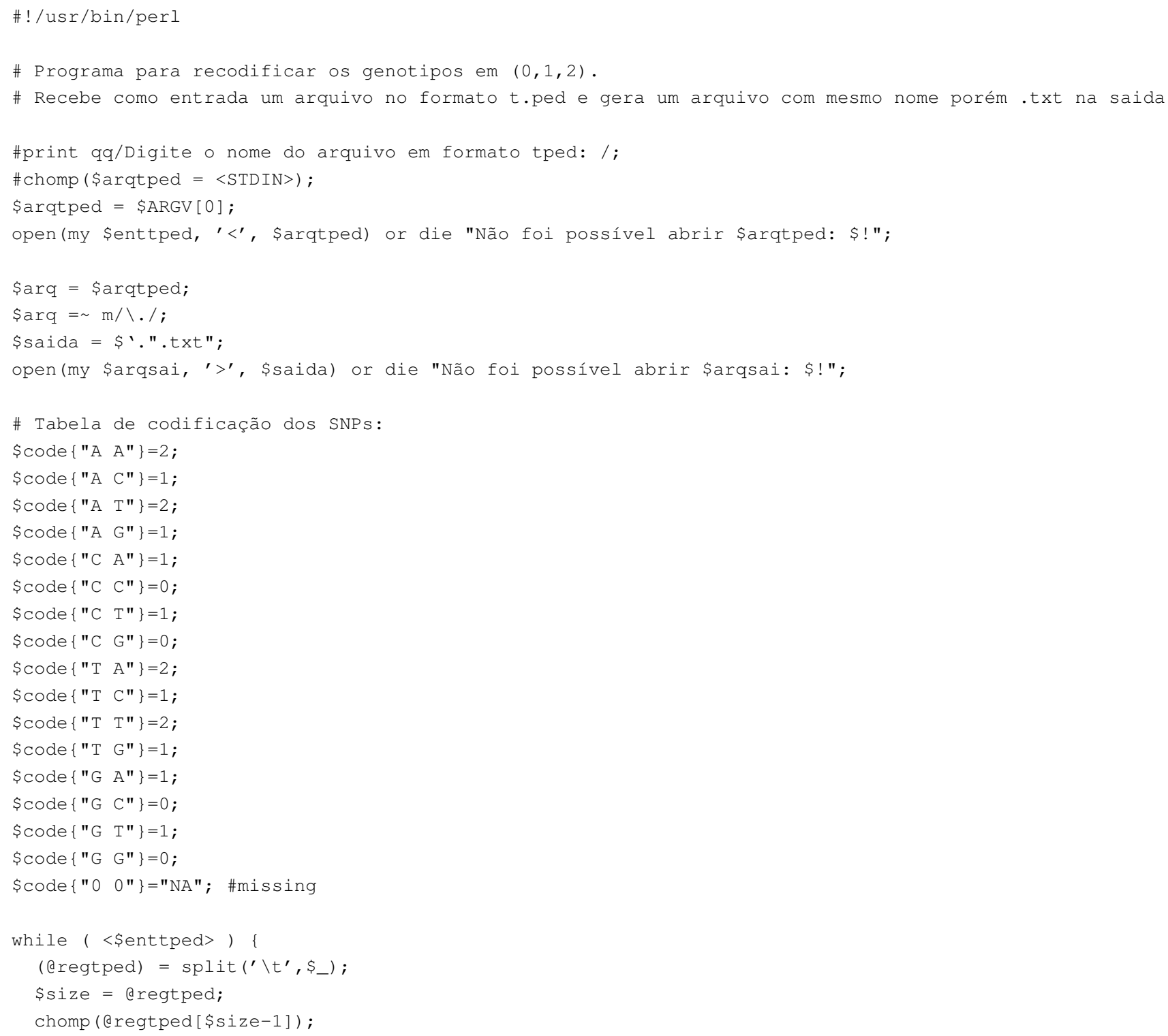




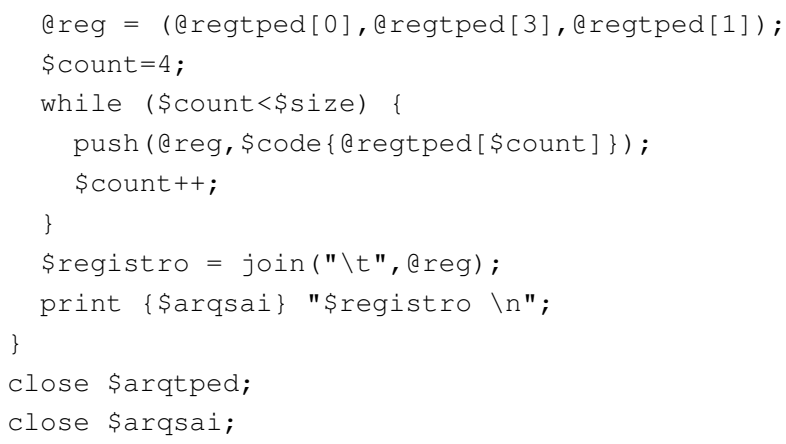




\section{A.1.2 Janelas de Consenso}

Código fonte em linguagem $R$ utilizado para determinação das janelas de consenso maximais:

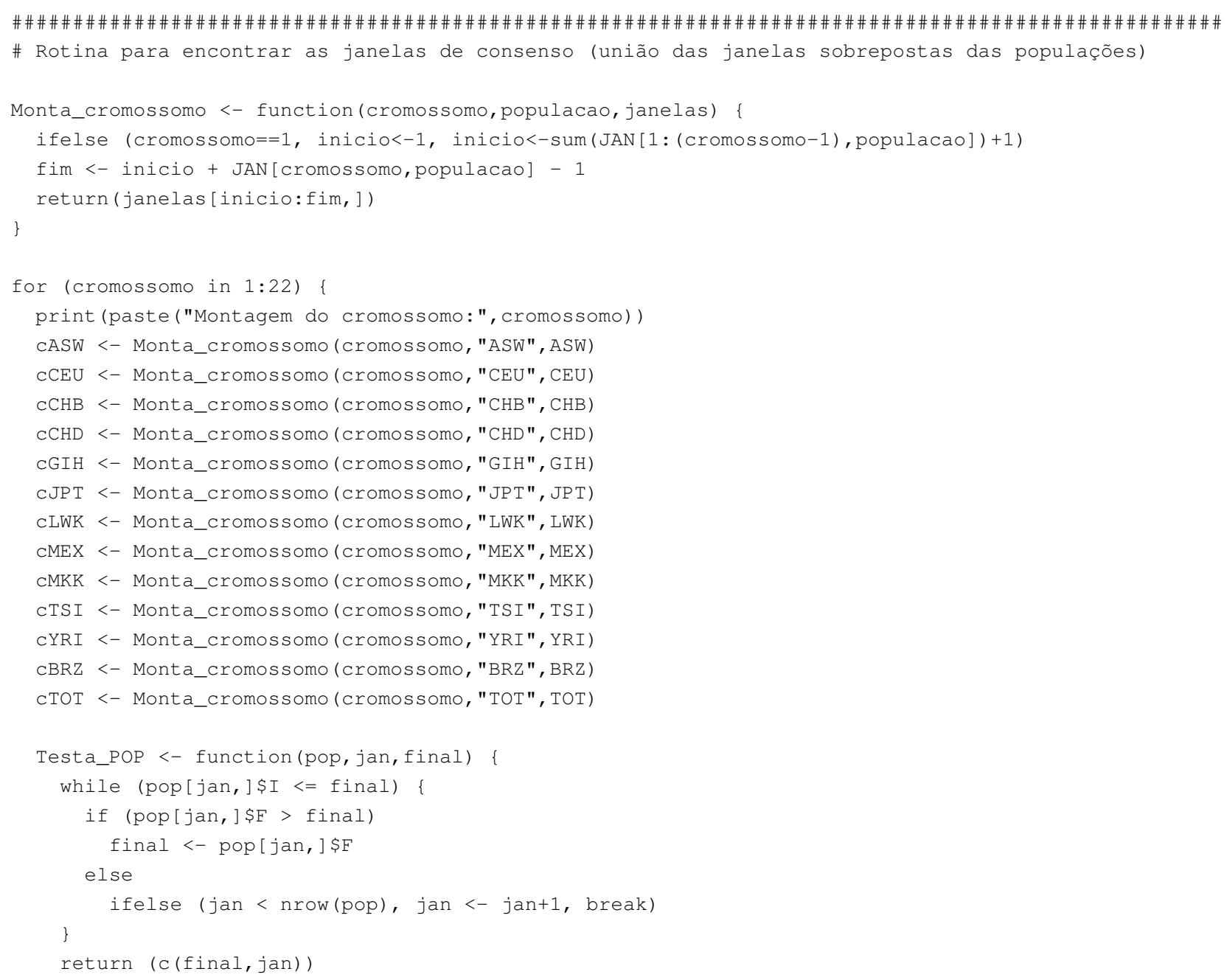




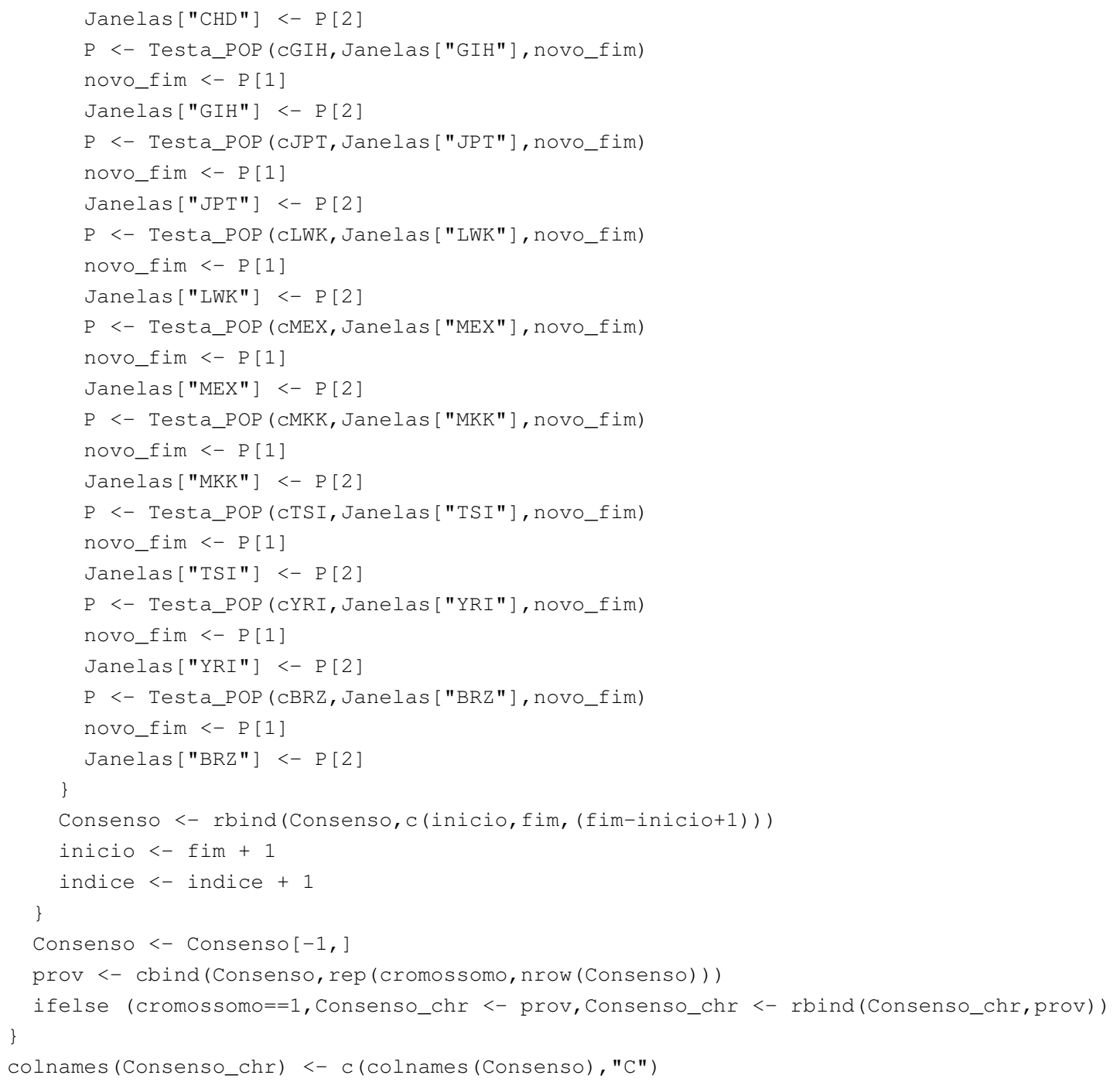




\section{A.1.3 Classificador}

Código fonte em linguagem $R$ utilizado para o classificador:

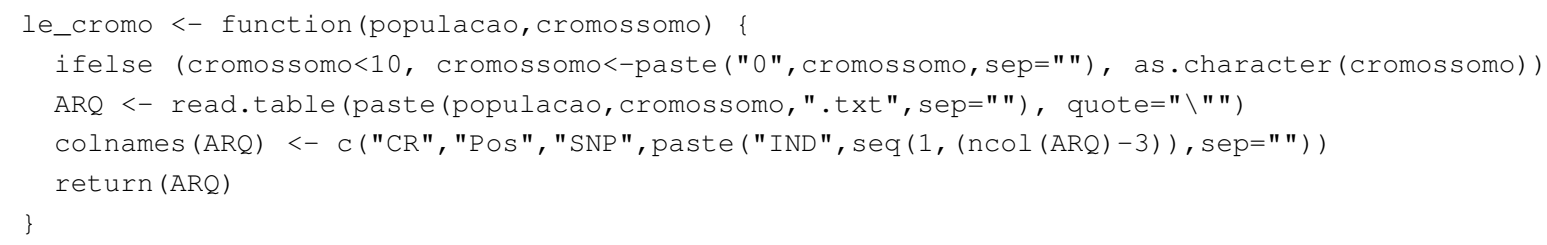




\section{A.2 Tabelas}

Tabela A.1 Classificação utilizando mapa Biplot

\begin{tabular}{|c|c|c|c|c|c|c|c|c|c|c|c|c|}
\hline & ASW & CEU & $\mathrm{CHB}$ & CHD & $\mathrm{GIH}^{3}$ & JPT & LWK & MEX & MKK & TSI & YRI & BRZ \\
\hline 515 LWK & 162 & 103 & 80 & 68 & 114 & 98 & 228 & 107 & 239 & 74 & 196 & 172 \\
\hline $731 \mathrm{MKK}$ & 144 & 112 & 90 & 75 & 137 & 82 & 143 & 109 & 323 & 94 & 156 & 175 \\
\hline 800 TSI & 73 & 249 & 113 & 104 & 178 & 109 & 56 & 145 & 103 & 243 & 72 & 197 \\
\hline $163 \mathrm{CHB}$ & 62 & 111 & 236 & 237 & 162 & 232 & 68 & 148 & 79 & 111 & 74 & 114 \\
\hline 232 CHB & 65 & 129 & 257 & 217 & 163 & 218 & 58 & 155 & 83 & 91 & 87 & 110 \\
\hline 1089 BRZ & 88 & 206 & 92 & 104 & 149 & 101 & 88 & 170 & 148 & 136 & 96 & 257 \\
\hline $521 \mathrm{LWK}$ & 164 & 94 & 75 & 71 & 103 & 89 & 264 & 93 & 240 & 73 & 200 & 164 \\
\hline $1027 \mathrm{BRZ}$ & 67 & 224 & 85 & 109 & 169 & 110 & 61 & 165 & 89 & 216 & 78 & 269 \\
\hline $726 \mathrm{MKK}$ & 147 & 106 & 73 & 83 & 114 & 89 & 149 & 120 & 342 & 88 & 164 & 163 \\
\hline $654 \mathrm{MKK}$ & 142 & 103 & 90 & 90 & 117 & 106 & 149 & 110 & 294 & 87 & 171 & 183 \\
\hline $991 \mathrm{BRZ}$ & 87 & 209 & 80 & 101 & 145 & 118 & 73 & 158 & 119 & 173 & 93 & 271 \\
\hline 518 LWK & 153 & 92 & 84 & 78 & 108 & 77 & 232 & 89 & 257 & 82 & 199 & 181 \\
\hline 1099 BRZ & 95 & 169 & 94 & 93 & 150 & 110 & 82 & 148 & 116 & 169 & 115 & 295 \\
\hline 935 YRI & 193 & 97 & 80 & 67 & 96 & 95 & 160 & 95 & 248 & 73 & 265 & 168 \\
\hline $156 \mathrm{CEU}$ & 84 & 287 & 97 & 106 & 170 & 110 & 54 & 182 & 83 & 177 & 63 & 214 \\
\hline 964 YRI & 174 & 99 & 84 & 76 & 104 & 84 & 178 & 87 & 210 & 65 & 292 & 187 \\
\hline 885 YRI & 205 & 93 & 74 & 78 & 95 & 87 & 197 & 89 & 217 & 74 & 256 & 172 \\
\hline 528 LWK & 170 & 98 & 86 & 79 & 116 & 81 & 229 & 94 & 236 & 69 & 205 & 179 \\
\hline 626 MEX & 84 & 187 & 92 & 106 & 162 & 127 & 70 & 235 & 108 & 167 & 77 & 224 \\
\hline 870 TSI & 69 & 221 & 108 & 99 & 171 & 108 & 59 & 165 & 110 & 251 & 77 & 198 \\
\hline 893 YRI & 180 & 98 & 67 & 81 & 101 & 102 & 178 & 102 & 246 & 76 & 258 & 154 \\
\hline $388 \mathrm{GIH}$ & 66 & 173 & 110 & 120 & 307 & 129 & 76 & 159 & 103 & 144 & 85 & 166 \\
\hline 970 YRI & 178 & 87 & 70 & 81 & 99 & 88 & 164 & 125 & 221 & 80 & 265 & 187 \\
\hline $750 \mathrm{MKK}$ & 129 & 134 & 83 & 75 & 134 & 89 & 149 & 111 & 297 & 102 & 151 & 188 \\
\hline 608 MEX & 82 & 205 & 96 & 111 & 164 & 121 & 55 & 247 & 99 & 183 & 84 & 189 \\
\hline 853 TSI & 83 & 201 & 103 & 110 & 158 & 113 & 76 & 140 & 97 & 254 & 77 & 224 \\
\hline $525 \mathrm{LWK}$ & 156 & 105 & 80 & 76 & 102 & 78 & 223 & 107 & 229 & 98 & 194 & 192 \\
\hline $368 \mathrm{GIH}$ & 73 & 183 & 135 & 106 & 293 & 122 & 61 & 158 & 102 & 159 & 89 & 162 \\
\hline $315 \mathrm{CHD}$ & 60 & 129 & 193 & 281 & 167 & 207 & 58 & 141 & 89 & 87 & 75 & 133 \\
\hline 838 TSI & 74 & 233 & 110 & 99 & 162 & 111 & 64 & 142 & 95 & 271 & 81 & 193 \\
\hline 552 LWK & 161 & 95 & 76 & 72 & 110 & 88 & 261 & 89 & 233 & 78 & 208 & 173 \\
\hline $452 \mathrm{JPT}$ & 65 & 122 & 210 & 197 & 140 & 316 & 55 & 151 & 97 & 96 & 75 & 121 \\
\hline 947 YRI & 170 & 107 & 62 & 90 & 92 & 86 & 174 & 77 & 239 & 70 & 296 & 180 \\
\hline 38 ASW & 221 & 124 & 82 & 78 & 126 & 88 & 157 & 107 & 197 & 89 & 169 & 195 \\
\hline $301 \mathrm{CHD}$ & 81 & 123 & 215 & 258 & 148 & 219 & 60 & 148 & 76 & 110 & 77 & 121 \\
\hline 1077 BRZ & 97 & 189 & 103 & 113 & 133 & 111 & 91 & 162 & 132 & 144 & 106 & 254 \\
\hline 920 YRI & 178 & 81 & 78 & 75 & 118 & 86 & 187 & 80 & 220 & 78 & 293 & 169 \\
\hline 843 TSI & 68 & 218 & 88 & 97 & 181 & 108 & 75 & 172 & 101 & 260 & 65 & 209 \\
\hline $68 \mathrm{CEU}$ & 78 & 290 & 113 & 90 & 154 & 125 & 52 & 155 & 96 & 203 & 81 & 203 \\
\hline $447 \mathrm{JPT}$ & 60 & 116 & 193 & 213 & 164 & 300 & 66 & 150 & 89 & 111 & 75 & 100 \\
\hline $413 \mathrm{GIH}$ & 74 & 191 & 116 & 139 & 278 & 121 & 76 & 149 & 105 & 140 & 83 & 172 \\
\hline $434 \mathrm{JPT}$ & 62 & 122 & 204 & 210 & 147 & 291 & 67 & 142 & 85 & 98 & 73 & 142 \\
\hline $996 \mathrm{BRZ}$ & 69 & 230 & 100 & 96 & 166 & 114 & 71 & 154 & 108 & 210 & 73 & 246 \\
\hline $83 \mathrm{CEU}$ & 55 & 300 & 89 & 106 & 164 & 105 & 61 & 177 & 116 & 180 & 71 & 209 \\
\hline $205 \mathrm{CHB}$ & 82 & 126 & 255 & 214 & 137 & 233 & 60 & 149 & 84 & 116 & 73 & 113 \\
\hline 1046 BRZ & 117 & 180 & 82 & 91 & 153 & 111 & 87 & 144 & 148 & 141 & 122 & 257 \\
\hline 1102 BRZ & 93 & 214 & 86 & 98 & 156 & 120 & 51 & 165 & 105 & 182 & 69 & 273 \\
\hline 948 YRI & 186 & 91 & 82 & 82 & 110 & 71 & 184 & 86 & 211 & 75 & 285 & 179 \\
\hline 699 MKK & 150 & 97 & 77 & 96 & 100 & 98 & 156 & 109 & 319 & 90 & 168 & 182 \\
\hline $990 \mathrm{BRZ}$ & 111 & 187 & 106 & 106 & 149 & 97 & 80 & 149 & 143 & 147 & 99 & 268 \\
\hline 1078 BRZ & 88 & 207 & 94 & 80 & 181 & 114 & 76 & 152 & 95 & 175 & 68 & 266 \\
\hline 973 YRI & 187 & 85 & 60 & 69 & 97 & 81 & 177 & 101 & 228 & 87 & 279 & 186 \\
\hline $51 \mathrm{CEU}$ & 80 & 284 & 95 & 100 & 173 & 102 & 62 & 187 & 98 & 180 & 69 & 202 \\
\hline 682 MKK & 145 & 131 & 86 & 93 & 121 & 84 & 149 & 115 & 299 & 89 & 155 & 176 \\
\hline $406 \mathrm{GIH}$ & 72 & 179 & 121 & 134 & 258 & 131 & 76 & 161 & 88 & 160 & 83 & 181 \\
\hline $32 \mathrm{ASW}$ & 230 & 113 & 87 & 69 & 114 & 91 & 142 & 108 & 211 & 99 & 192 & 183 \\
\hline $94 \mathrm{CEU}$ & 69 & 318 & 102 & 100 & 159 & 106 & 62 & 161 & 92 & 183 & 75 & 212 \\
\hline 19 ASW & 205 & 141 & 83 & 94 & 148 & 110 & 121 & 135 & 172 & 91 & 132 & 198 \\
\hline 503 LWK & 140 & 99 & 74 & 79 & 105 & 91 & 238 & 89 & 248 & 84 & 213 & 180 \\
\hline 833 TSI & 86 & 234 & 79 & 111 & 157 & 109 & 55 & 166 & 96 & 270 & 75 & 203 \\
\hline $167 \mathrm{CHB}$ & 70 & 127 & 270 & 227 & 154 & 239 & 39 & 144 & 88 & 91 & 58 & 134 \\
\hline $178 \mathrm{CHB}$ & 64 & 114 & 267 & 223 & 144 & 226 & 63 & 150 & 93 & 86 & 61 & 125 \\
\hline $148 \mathrm{CEU}$ & 75 & 310 & 105 & 108 & 170 & 111 & 63 & 183 & 85 & 188 & 64 & 179 \\
\hline $206 \mathrm{CHB}$ & 51 & 126 & 247 & 239 & 152 & 216 & 61 & 147 & 84 & 98 & 83 & 140 \\
\hline
\end{tabular}


Tabela A.1 Classificação utilizando mapa Biplot (continuação)

\begin{tabular}{|c|c|c|c|c|c|c|c|c|c|c|c|c|}
\hline & ASW & CEU & $\mathrm{CHB}$ & CHD & GIH & JPT & LWK & MEX & MKK & TSI & YRI & BRZ \\
\hline $108 \mathrm{CEU}$ & 78 & 305 & 98 & 91 & 165 & 120 & 60 & 149 & 95 & 188 & 65 & 229 \\
\hline 1023 BRZ & 113 & 168 & 86 & 96 & 142 & 110 & 81 & 181 & 157 & 136 & 106 & 266 \\
\hline $760 \mathrm{MKK}$ & 133 & 131 & 87 & 84 & 104 & 83 & 150 & 119 & 302 & 99 & 167 & 184 \\
\hline 875 YRI & 184 & 95 & 65 & 83 & 97 & 81 & 179 & 93 & 273 & 69 & 262 & 161 \\
\hline $334 \mathrm{GIH}$ & 77 & 186 & 126 & 128 & 268 & 138 & 62 & 165 & 102 & 145 & 80 & 162 \\
\hline $374 \mathrm{GIH}$ & 72 & 182 & 146 & 137 & 279 & 125 & 64 & 152 & 89 & 131 & 81 & 185 \\
\hline $217 \mathrm{CHB}$ & 70 & 120 & 275 & 233 & 162 & 200 & 55 & 151 & 86 & 94 & 75 & 122 \\
\hline 1041 BRZ & 66 & 213 & 96 & 109 & 144 & 117 & 69 & 156 & 114 & 189 & 72 & 294 \\
\hline 308 CHD & 61 & 108 & 210 & 273 & 145 & 235 & 64 & 138 & 97 & 91 & 89 & 127 \\
\hline $23 \mathrm{ASW}$ & 221 & 103 & 82 & 81 & 100 & 86 & 182 & 103 & 202 & 88 & 206 & 188 \\
\hline $490 \mathrm{JPT}$ & 74 & 133 & 186 & 211 & 160 & 297 & 51 & 150 & 87 & 94 & 70 & 115 \\
\hline $441 \mathrm{JPT}$ & 68 & 122 & 201 & 198 & 153 & 304 & 53 & 139 & 78 & 109 & 90 & 124 \\
\hline 519 LWK & 174 & 86 & 72 & 65 & 100 & 82 & 236 & 110 & 237 & 78 & 215 & 186 \\
\hline 819 TSI & 68 & 246 & 100 & 103 & 159 & 114 & 61 & 150 & 115 & 241 & 78 & 205 \\
\hline $704 \mathrm{MKK}$ & 149 & 111 & 65 & 86 & 127 & 90 & 169 & 110 & 271 & 114 & 163 & 182 \\
\hline 891 YRI & 169 & 80 & 76 & 83 & 112 & 79 & 195 & 90 & 230 & 79 & 245 & 188 \\
\hline 906 YRI & 163 & 90 & 62 & 78 & 107 & 98 & 182 & 104 & 225 & 78 & 269 & 188 \\
\hline $22 \mathrm{ASW}$ & 261 & 122 & 66 & 81 & 95 & 100 & 153 & 103 & 194 & 97 & 167 & 200 \\
\hline $162 \mathrm{CHB}$ & 66 & 105 & 262 & 222 & 149 & 243 & 55 & 165 & 76 & 101 & 68 & 126 \\
\hline 937 YRI & 177 & 97 & 74 & 98 & 114 & 92 & 180 & 76 & 212 & 70 & 281 & 162 \\
\hline 933 YRI & 180 & 89 & 68 & 83 & 104 & 87 & 195 & 90 & 211 & 76 & 264 & 194 \\
\hline $440 \mathrm{JPT}$ & 60 & 129 & 213 & 198 & 170 & 283 & 67 & 162 & 88 & 96 & 64 & 112 \\
\hline $680 \mathrm{MKK}$ & 130 & 122 & 81 & 70 & 116 & 96 & 152 & 125 & 303 & 101 & 165 & 179 \\
\hline 901 YRI & 197 & 104 & 68 & 79 & 116 & 80 & 192 & 84 & 210 & 66 & 268 & 173 \\
\hline 616 MEX & 69 & 156 & 129 & 118 & 137 & 132 & 74 & 282 & 98 & 137 & 89 & 198 \\
\hline $144 \mathrm{CEU}$ & 73 & 314 & 94 & 99 & 153 & 102 & 58 & 197 & 97 & 197 & 62 & 191 \\
\hline 635 MEX & 58 & 169 & 109 & 111 & 167 & 137 & 60 & 306 & 78 & 163 & 84 & 202 \\
\hline 856 TSI & 74 & 231 & 110 & 105 & 165 & 123 & 74 & 140 & 98 & 262 & 62 & 200 \\
\hline 1062 BRZ & 122 & 160 & 93 & 110 & 143 & 112 & 72 & 161 & 140 & 163 & 89 & 253 \\
\hline 613 MEX & 80 & 147 & 131 & 132 & 166 & 147 & 63 & 316 & 89 & 118 & 78 & 171 \\
\hline 590 LWK & 172 & 90 & 78 & 69 & 120 & 88 & 228 & 92 & 243 & 81 & 206 & 177 \\
\hline 903 YRI & 190 & 93 & 61 & 59 & 100 & 86 & 191 & 96 & 234 & 74 & 286 & 175 \\
\hline 984 YRI & 181 & 84 & 77 & 78 & 105 & 96 & 173 & 84 & 223 & 79 & 261 & 203 \\
\hline $25 \mathrm{ASW}$ & 255 & 123 & 68 & 78 & 110 & 88 & 162 & 89 & 215 & 77 & 183 & 193 \\
\hline $208 \mathrm{CHB}$ & 63 & 114 & 271 & 213 & 147 & 225 & 56 & 148 & 110 & 93 & 75 & 122 \\
\hline 1059 BRZ & 92 & 143 & 70 & 84 & 120 & 79 & 71 & 121 & 122 & 108 & 89 & 272 \\
\hline SOMA & 11689 & 15279 & 11460 & 11654 & 14490 & 12845 & 11346 & 13907 & 15904 & 12648 & 13637 & 18621 \\
\hline
\end{tabular}

Tabela A.1: Classificação utilizando mapa Biplot 


\section{A.3 Figuras}



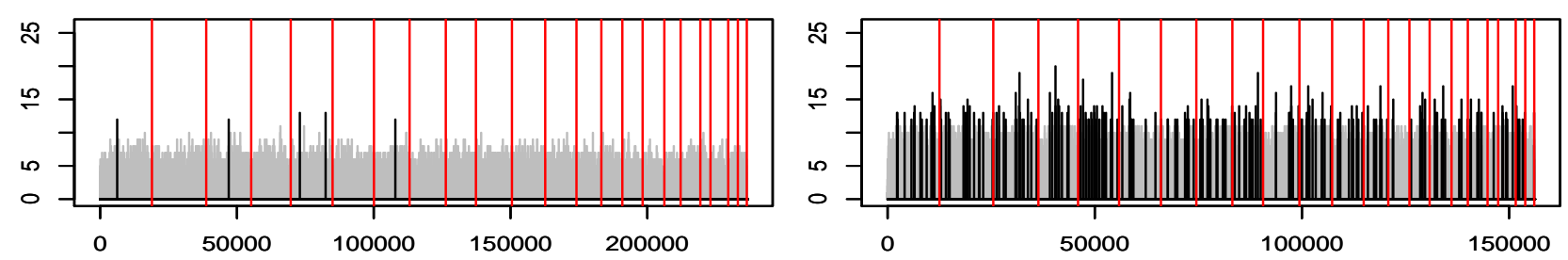

Janelas da População ASW

Janelas da População CEU
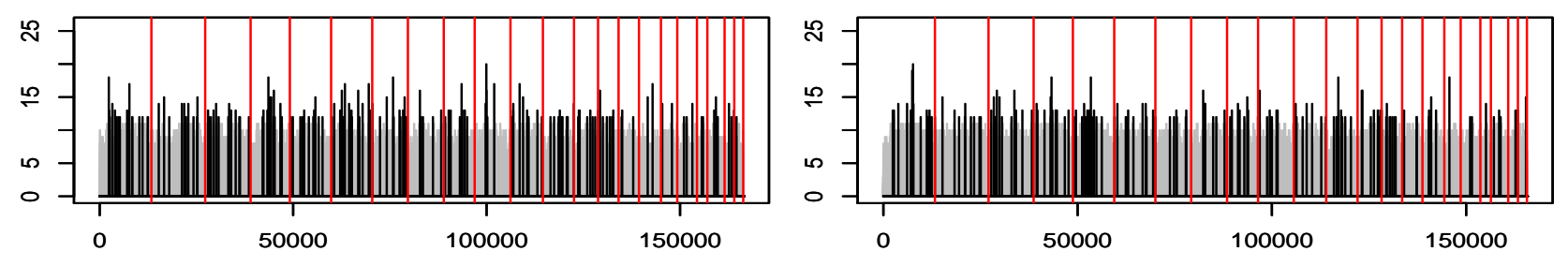

Janelas da População CHB
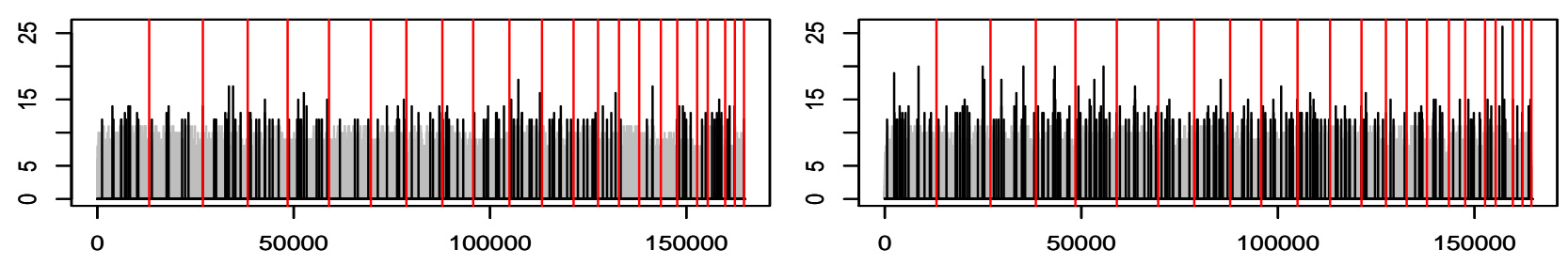

Janelas da População GIH
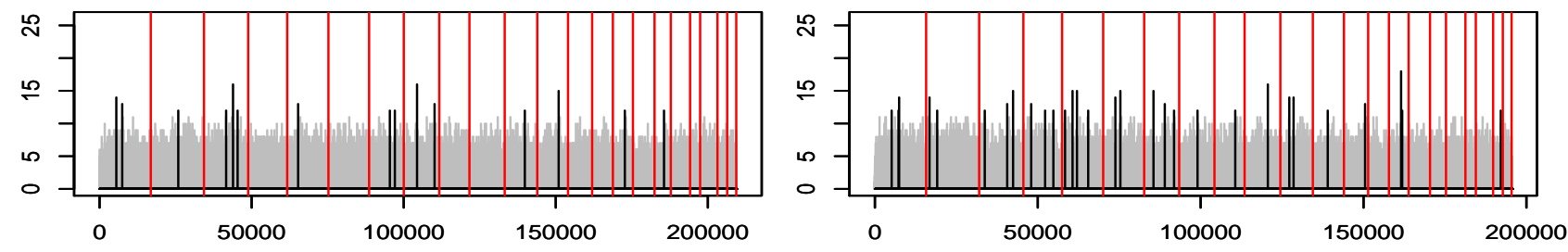

Janelas da População LWK
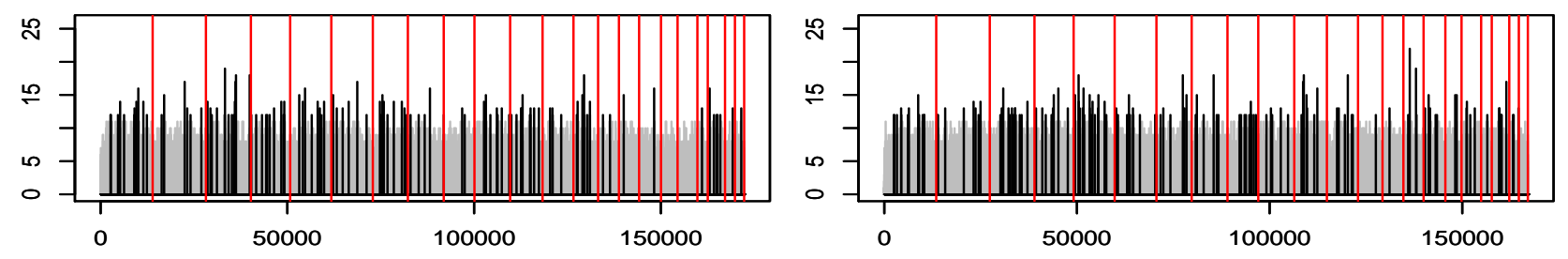

Janelas da População MKK

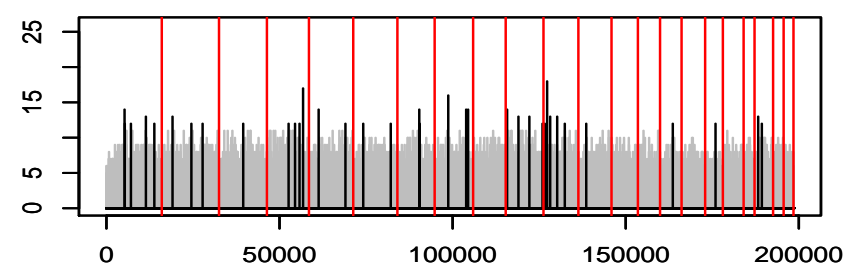

Janelas da População YRI

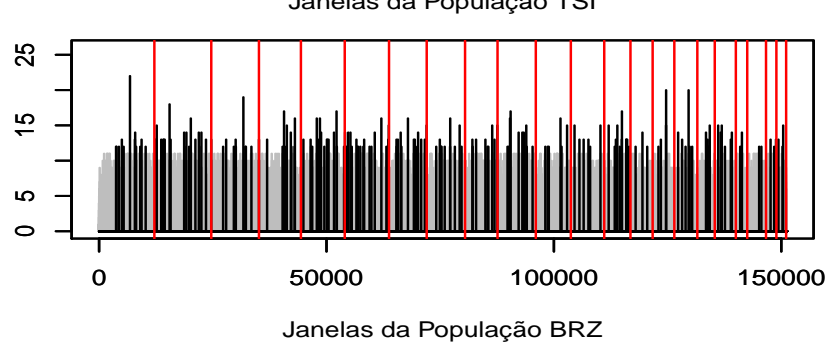

Figura A.1: Distribuição das janelas 'grandes' em cada população do estudo. 

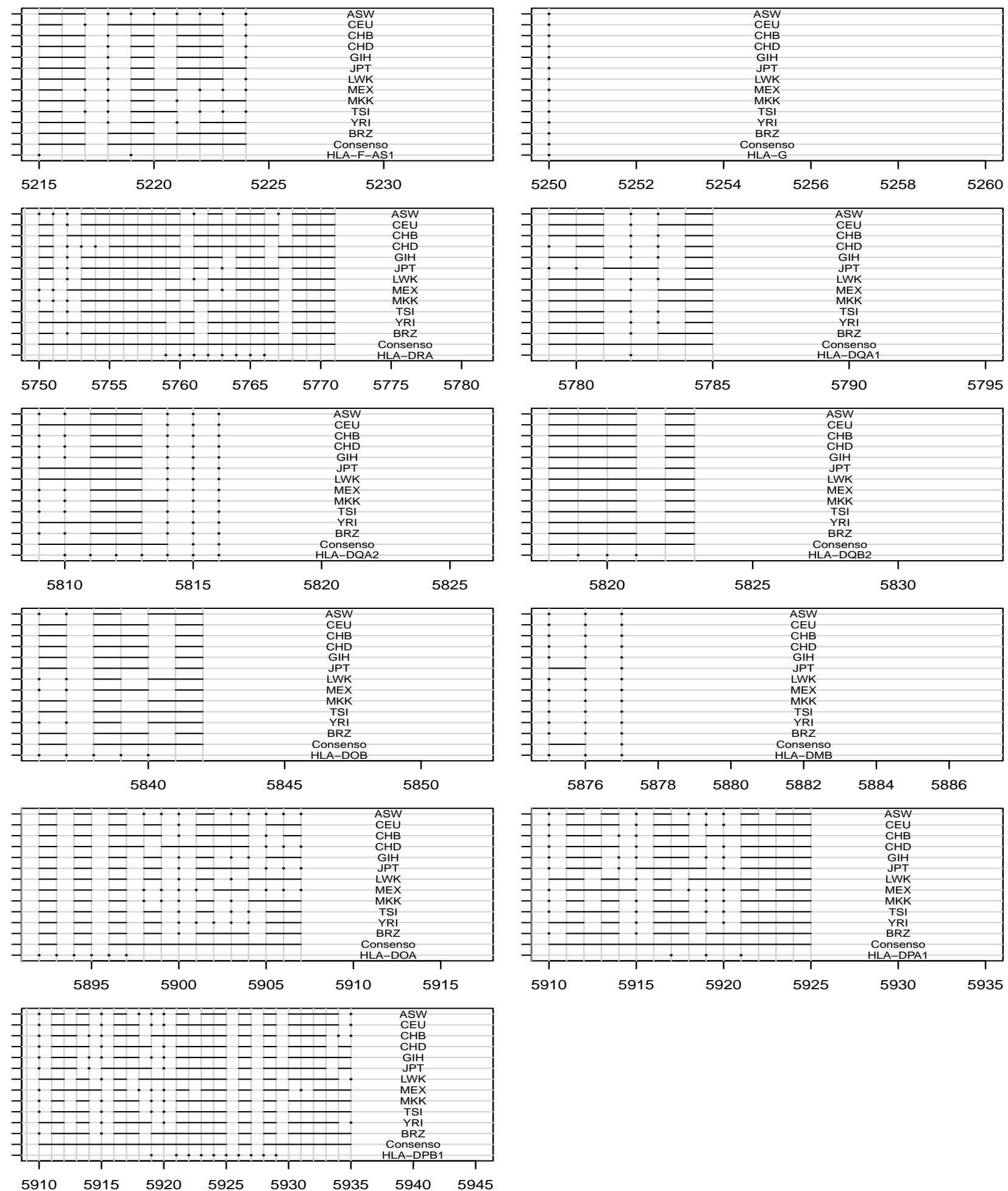

Figura A.2: Janelas encontradas nas regiões dos SNPs da região do HLA. 


\section{Referências Bibliográficas}

Bansal et al.(2008) Vikas Bansal, Aaron L Halpern, Nelson Axelrod e Vineet Bafna. An mcmc algorithm for haplotype assembly from whole-genome sequence data. Genome research, 18(8): 1336-1346. Citado na pág. 4

Beck et al.(2014) Tim Beck, Robert K Hastings, Sirisha Gollapudi, Robert C Free e Anthony J Brookes. Gwas central: a comprehensive resource for the comparison and interrogation of genomewide association studies. European Journal of Human Genetics, 22(7):949-952. Citado na pág. 38

Besag(1975) Julian Besag. Statistical analysis of non-lattice data. The statistician, páginas 179195. Citado na pág. 13

Bianchi(2009) André Jucovsky Bianchi. Vizinhanças e janelas de influência em polimorfismos de umunico nucleotıdeo, 2009. Citado na pág. 6, 9, 13, 14, 28, 45

Bourgain et al.(2002) Catherine Bourgain, Emmanuelle Genin e Francoise Clerget-Darpoux. Comparison of family based haplotype methods using intragenic snps in candidate genes. European Journal of Human Genetics, 10(5):313-319. Citado na pág. 4

Bühlmann et al.(1999) Peter Bühlmann, Abraham J Wyner et al. Variable length markov chains. The Annals of Statistics, 27(2):480-513. Citado na pág. 11

Cavalli-Sforza(1996) Luigi Luca Cavalli-Sforza. Genes, povos e línguas. Instituto Piaget. Citado na pág. 4

Coelho et al.(2014) AV Coelho, RR Moura, CA Cavalcanti, RL Guimarães, P Sandrin-Garcia, S Crovella e LA Brandão. A rapid screening of ancestry for genetic association studies in an admixed population from pernambuco, brazil. Genetics and molecular research: GMR, 14(1): 2876-2884. Citado na pág. 4

Consortium et al.(2005) International HapMap Consortium et al. A haplotype map of the human genome. Nature, 437(7063):1299-1320. Citado na pág. 2

Csiszár e Talata(2006) Imre Csiszár e Zsolt Talata. Context tree estimation for not necessarily finite memory processes, via bic and mdl. Information Theory, IEEE Transactions on, 52(3): 1007-1016. Citado na pág. 14

Druet e Georges(2010) Tom Druet e Michel Georges. A hidden markov model combining linkage and linkage disequilibrium information for haplotype reconstruction and quantitative trait locus fine mapping. Genetics, 184(3):789-798. Citado na pág. 3, 4

Gabriel(2002) K Ruben Gabriel. Goodness of fit of biplots and correspondence analysis. Biometrika, 89(2):423-436. Citado na pág. 25

Geraci(2010) Filippo Geraci. A comparison of several algorithms for the single individual snp haplotyping reconstruction problem. Bioinformatics, 26(18):2217-2225. Citado na pág. 1 
Giolo et al.(2012) Suely R Giolo, Julia MP Soler, Steven C Greenway, Marcio AA Almeida, Mariza de Andrade, JG Seidman, Christine E Seidman, José E Krieger e Alexandre C Pereira. Brazilian urban population genetic structure reveals a high degree of admixture. European Journal of Human Genetics, 20(1):111-116. Citado na pág. 5, 27

Greenacre(2007) Michael Greenacre. Correspondence analysis in practice. CRC press. Citado na pág. $22,23,24,25,26,41$

Greenspan e Geiger(2006) G Greenspan e Dan Geiger. Modeling haplotype block variation using markov chains. Genetics, 172(4):2583-2599. Citado na pág. xii, 4, 48, 49

Jorde(1995) Lynn B Jorde. Linkage disequilibrium as a gene-mapping tool. American journal of human genetics, 56(1):11. Citado na pág. 3

Kim et al.(2008) Yunjung Kim, Sheng Feng e Zhao-Bang Zeng. Measuring and partitioning the high-order linkage disequilibrium by multiple order markov chains. Genetic epidemiology, 32(4): 301-312. Citado na pág. 4

Lange(2002) Kenneth Lange. Mathematical and statistical methods for genetic analysis. Springer Science \& Business Media. Citado na pág. 3

Leonardi et al.(2010) Florencia Leonardi et al. Some upper bounds for the rate of convergence of penalized likelihood context tree estimators. Brazilian Journal of Probability and Statistics, 24 (2):321-336. Citado na pág. 9

Leonardi(2006) Florencia G Leonardi. A generalization of the pst algorithm: modeling the sparse nature of protein sequences. Bioinformatics, 22(11):1302-1307. Citado na pág. 45

Leonardi(2007) Florencia Graciela Leonardi. Cadeias estocásticas parcimoniosas com aplicaçoesa classificaçao e filogenia das seqüências de proternas. Tese de Doutorado, Universidade de São Paulo. Citado na pág. 6, 9, 45

Lesk(2005) Arthur M Lesk. Introdução à bioinformática. Artmed. Citado na pág. 1, 2, 45

Löcherbach e Orlandi(2011) Eva Löcherbach e Enza Orlandi. Neighborhood radius estimation for variable-neighborhood random fields. Stochastic Processes and their Applications, 121(9): 2151-2185. Citado na pág. 11

Nassir et al.(2009) Rami Nassir, Roman Kosoy, Chao Tian, Phoebe A White, Lesley M Butler, Gabriel Silva, Rick Kittles, Marta E Alarcon-Riquelme, Peter K Gregersen, John W Belmont et al. An ancestry informative marker set for determining continental origin: validation and extension using human genome diversity panels. BMC genetics, 10(1):39. Citado na pág. 4

Pena et al.(2000) Sérgio DJ Pena, Denise R Carvalho-Silva, Juliana Alves-Silva, Vânia F Prado e Fabrício R Santos. Retrato molecular do brasil. Ciência hoje, 27(159):16-25. Citado na pág. 4

Price et al.(2006) Alkes L Price, Nick J Patterson, Robert M Plenge, Michael E Weinblatt, Nancy A Shadick e David Reich. Principal components analysis corrects for stratification in genome-wide association studies. Nature genetics, 38(8):904-909. Citado na pág. 5

Purcell et al.(2007) Shaun Purcell, Benjamin Neale, Kathe Todd-Brown, Lori Thomas, Manuel AR Ferreira, David Bender, Julian Maller, Pamela Sklar, Paul IW De Bakker, Mark J Daly et al. Plink: a tool set for whole-genome association and population-based linkage analyses. The American Journal of Human Genetics, 81(3):559-575. Citado na pág. 27

Rissanen et al.(1983) Jorma Rissanen et al. A universal data compression system. IEEE Transactions on information theory, 29(5):656-664. Citado na pág. 12 
Robinson et al.(2015) James Robinson, Jason A Halliwell, James D Hayhurst, Paul Flicek, Peter Parham e Steven GE Marsh. HLA nomenclature @ hla.alleles.org, 2015. URL http://hla.alleles. org. Citado na pág. 38

Schlesinger(2010) David Schlesinger. Ancestralidade da população de São Paulo e correlação com alterações neuropatológicas no idoso. Tese de Doutorado, Universidade de São Paulo. Citado na pág. $4,30,46$

Slatkin(2008) Montgomery Slatkin. Linkage disequilibrium?understanding the evolutionary past and mapping the medical future. Nature Reviews Genetics, 9(6):477-485. Citado na pág. 3

Zucchelli e Kere(2003) M Zucchelli e J Kere. Haploblocks, a software tool for visualization and analysis of haplotype blocks in the human genome. Em AMERICAN JOURNAL OF HUMAN GENETICS, volume 73, páginas 366-366. UNIV CHICAGO PRESS 1427 E 60TH ST, CHICAGO, IL 60637-2954 USA. Citado na pág. 48 